\title{
The granite-related, high-tonnage Sn-Li deposit of Argemela, central Portugal
}

\section{O depósito de $\mathrm{Sn}-\mathrm{Li}$ associado a granito, de grande tonelagem da Argemela, Portugal central}

INVERNO, C. M. C. ${ }^{*}$, FERRAZ, P. J. V. ${ }^{2}$, MOREIRA, M. E. ${ }^{3}$, F. GUIMARÃES, F. ${ }^{3}$ AND FILIPE, A. ${ }^{1}$

${ }^{1}$ Laboratório Nacional de Energia e Geologia (LNEG), Unidade de Recursos Minerais e Geofísica, Apartado 7586, Alfragide, 2610-999 Amadora, Portugal. carlos.inverno@lneg.pt, augusto.filipe@lneg.pt ${ }^{2}$ Beralt Tin \& Wolfram Portugal (BTWP), Minas da Panasqueira, Barroca Grande, 6225-051 Aldeia de S. Francisco de Assis, Portugal. Present address: Geosingular, Lda, Rua do Amial, 258, $2^{\circ}$ Esq, 4200-054 Porto, Portugal.paulojvferraz@gmail.com

${ }^{3}$ Laboratório do LNEG, Unidade de Ciência e Tecnologia Mineral, Rua da Amieira, Apartado 1089, 4460-901 S. Mamede de Infesta, Portugal. fernanda.guimaraes@lneg.pt, eugenia.estudantina.moreira@ gmail.com

${ }^{*}$ Corresponding author

https://doi.org/10.17979/cadlaxe.2019.41.0.5823

enviado: $2 / 5 / 2019$ aceptado 10/6/2019

\begin{abstract}
The Argemela Sn-Li quartz vein stockwork, east of the Panasqueira tungsten mine, is hosted in Cambrian slates and greywacke. An underlying Variscan granitic cupola is inferred from spotted slates and albitic microgranite dykes, the last including a thick modified albitic microgranite, enriched in $\mathrm{F}$ and $\mathrm{Li}$, exposed some $500 \mathrm{~m}$ away, on the hill top. Inferred resources for shallowest deposit portion are 20.1 million tonnes (Mt) at $0.1-0.2 \% \mathrm{Sn}, 0.2 \% \mathrm{Li}$ and $0.1 \%$ (estimate) $\mathrm{Rb}$, but the 650 -m vertical-extent of the deposit suggests a resource of
\end{abstract}


$>200 \mathrm{Mt}$ (with identical grades). The hydrothermal paragenetic sequence is amblygonitemontebrasite (mostly montebrasite) (Stage I) - quartz I-II-cassiterite (with columbite-tantalite inclusions)-arsenopyrite I-carbonate I-white mica I -chlorite I-fluorite-apatite-rutile (Stage II) - white mica II-molybdenite- tourmaline- carbonate II-quartz III-arsenopyrite II-sphalerite-stannite-chalcopyrite-pyrite- pyrrhotite-chlorite II (Stage III)-covellitevivianite-goethite/lepidocrocite (Stage IV). Amblygonite-montebrasite is the main Li carrier; $\mathrm{Sn}$ is evenly distributed between cassiterite and stannite; $\mathrm{Rb}$ is mostly in white mica (with $0.25-1.23 \mathrm{wt} \% \mathrm{Rb}_{2} \mathrm{O}$ in the hill-top albitic microgranite). Primary aqueous, 1-3 um-wide fluid inclusions in the deposit in quartz I, carbonate I, apatite and cassiterite growth zones yield overall salinities and homogenisation temperatures of 7.2-19.1 $\mathrm{wt} \% \mathrm{NaCl}$ equiv. and $290-360^{\circ} \mathrm{C}$, respectively. The trace concentrations (electronic microprobe analysis) in quartz vein cassiterite reach $1.95 \mathrm{wt} \% \mathrm{Nb}, 0.39 \mathrm{wt} \% \mathrm{Fe}, 0.13 \mathrm{wt} \% \mathrm{Ti}$, and low/negligible values of $\mathrm{Sb}, \mathrm{Zn}, \mathrm{As}, \mathrm{Ag}$ and $\mathrm{Bi}$ showing its granite-hydrothermal affiliation. Fe-poor and Fe-rich sphalerite (lower-intermediate and upper deposit parts) contain 1.0-1.6 and 7.9-9.4 wt \% Fe, 64.3-66.0 and 55.9-57.2 wt \% Zn, 0.4-0.5 and 0.9-1.1 wt \% Cd, respectively. The sphaleritestannite geothermometer yields temperatures of $245-297^{\circ} \mathrm{C}$. Following higher temperature amblygonite-montebrasite deposition (Stage I), hydrothermal fluids $\left(\mathrm{a}_{\mathrm{Cl}}=0.25 \mathrm{~m}\right.$ ), related to the hidden granitic cupola, at a mean pressure-corrected $(50 \mathrm{MPa})$ temperature of $350^{\circ} \mathrm{C}$, were responsible for Stage II minerals deposition. Calculated cassiterite deposition from Sn chloride complexes occurred likewise, from probable magmatic-hydrothermal fluids, at $\mathrm{fO}_{2}$ $=10^{-34}-10^{-32} \mathrm{~atm}$ and $\mathrm{pH}=3.5-4$. Cassiterite deposition mechanisms were oxidation, mixing, neutralisation, possible $\mathrm{a}_{\mathrm{Cl}-}$ increase, and cooling. Later Fe-poor sphalerite (+kesterite/ferrokesterite) and Fe-rich sphalerite (+stannite) deposited at higher and lower $\mathrm{fS}_{2}$, respectively, the latter probably at a higher $\mathrm{fO}_{2}$ (Stage III). The uniqueness of Argemela system with abundant amblygonite-montebrasite in hydrothermal quartz tin veins may be related to an extreme fractionated F-, Li- and P-rich granitic magma. After the emplacement of the granite/albitic microgranite dykes, an emerging pegmatitic fluid was unable, possibly due to insufficient depth, to form pegmatites but only modified the hill-top albitic microgranite. As a consequence, the system, where mixing of high- and low-salinity magmatic fluids probably occurred, remained very enriched in F, Li and $\mathrm{P}$ and by the time the hydrothermal stockwork developed amblygonite-montebrasite (Stage I) was the first mineral to deposit abundantly before Stage II minerals deposition in those Argemela Sn-Li quartz veins.

Keywords: Granite-related; high-tonnage; Sn-Li stockwork quartz veins; amblygonitemontebrasite; cassiterite; $\mathrm{Th}=290-360^{\circ} \mathrm{C}$; $7-19$ wt \% NaCl equiv.; Argemela; Portugal 


\section{INTRODUCTION}

Argemela is a granite-related, dominantly slate-hosted, low-grade Sn-Li stockwork quartz vein deposit, of unusually high tonnage, in central Portugal, $10 \mathrm{~km}$ to the west of Fundão and $12 \mathrm{~km}$ to the east of the world famous Panasqueira tungsten deposit (Fig. 1), operated by Beralt Tin \& Wolfram Portugal, Ltd. (BTWP). The deposit, within a Sn-W province (THADEU, 1965), in the Iberian Massif, is relatively close to other granite-related Sn-W deposits, such as the large Panasqueira W-Sn-Cu deposit and the W-Sn deposits of Góis and Mata da Rainha (Fig. 1).

The deposit falls into the TAYLOR's (1979) category of granite-related quartzcassiterite veins, stockworks and greisens. However, it is unique, among other granite-related hydrothermal tin deposits in the region and worldwide, in its abundance of amblygonite-montebrasite in the Sn quartz veins, as if making the transition to Lipegmatite systems (RODA-ROBLES et al., 2011). Another particular characteristic of this Sn-Li hydrothermal deposit is the $>200$ Mt estimated total resource (INVERNO et al., 2009). In fact, the size of greisen- and several granite-related vein/stockwork-tin deposits worldwide is up to $80 \mathrm{Mt}$ (e.g., Altenberg, Germany), whereas Bolivian porphyry tin deposits contain up to several hundred million tonnes of ore (ECKSTRAND, 1984; COX and SINGER, 1986), implying that Argemela granite-related stockwork vein deposit may have the size (but not the genesis) of a porphyry-type deposit.

The classic localities for this group of vein - stockwork - greisen tin deposits are those of the Erzgebirge province, Germa- ny - Czech Republic, such as Altenberg, Zinnwald-Cinovec and Ehrenfriedersdorf, and also in Cornwall, England (e.g., Hemerdon, Geever and South Crofty), East Kemptville, Nova Scotia, Canada, Aberfoyle, Tasmania, Australia, the Malaysian tin fields of Kuala Lumpur - Kinta Valley and other deposits worldwide (BAUMANN, 1970; TAYLOR, 1979; LEHMANN, 1990). They are either low-grade $(0.2-0.3 \% \mathrm{Sn})$ or highgrade $(0.85-2.3 \% \mathrm{Sn})$ tin deposits, Aberfoyle being an example of the latter group (ECKSTRAND, 1984; COX and SINGER, 1986).

The model commonly proposed for the formation of these deposits invokes concentration of $\mathrm{Sn}$ in $\mathrm{B}-$ and/or F-rich fluid or vapour phases in relation to $\mathrm{SiO}_{2}-$ and $\mathrm{K}_{2} \mathrm{O}$ rich granitic magmas, in most cases derived from sedimentary rocks through melting (S-type granites), and deposition of tin minerals in fractures, faults, breccias and wall rocks of these structures (ECKSTRAND, 1984). The afore-mentioned phases cause the upward change from the normal granite, as microclinisation I, albitisation I and greisenisation, successively, due to an increasing acidity; subsequent decreasing acidity causes less extensive upwards albitisation II and finally microclinisation II (SHCHERBA, 1970; HU SHOUXI et al., 1982).

The unusual $\mathrm{Li}$ abundance and size of the Argemela deposit make it an worth studying uncommon granite-related quartz vein $\mathrm{Sn}$ deposit in view of understanding its different characteristics and genesis from average granite-related quartz vein $\mathrm{Sn}$ deposits. To do so petrography, bulk geochemical analysis, mineral chemistry and fluid inclusion work were conducted, and from their results depositional conditions were calculated and a model for the ore system was developed. 


\section{Mining and exploration history}

Former mine workings are in the steep slope of Argemela hill (745 m above sea level-ASL) and include three underground levels, at 522, 546 and $599 \mathrm{~m} \mathrm{ASL}$, and some opencasts, with the mineralised quartz veins occurring up to $650 \mathrm{~m}$ ASL. The mine produced some 1,000 tonnes (t) of cassiterite concentrates (with 50\% Sn) in 1942-1955 and when operated by BTWP in 1956-1961 produced $150 \mathrm{t}$ of cassiterite concentrates (with $73 \% \mathrm{Sn}$ ) at a mill recovery of $60 \%$. At the time, the resources were 80 million tonnes $(\mathrm{Mt})$ at $0.055 \% \mathrm{Sn}$, to a depth of $80 \mathrm{~m}$ below Level 522 as a few drill-holes indicated; these resources included measured resources of mineralised areas no. 1 (north) and no. 2 (south) (Fig. 2), with $6 \mathrm{Mt}$ at $0.08 \%$ Sn (NORRIS, 1962; STREETS, 1972; WHYTE, 1973).

Subsequent government exploration in 1977-1979 included three deep drill-holes (486, 451 and $586 \mathrm{~m}$ long), that intersected microgranite dykes at depth and proved the continuity of mineralization in between $650 \mathrm{~m}$ ASL and $0 \mathrm{~m}$ subsoil elevation $(0 \mathrm{~m}$ above sea level, at depth) and also that the area between mineralised areas no. 1 and no. 2, set by NORRIS (1962), was equally rich in Sn as those two, as soil geochemical profiles had formerly recognised (HOSKING, 1959). It also called the attention to the presence and high abundance of a $\mathrm{Li}$ ore mineral, amblygonite-montebrasite, in the Sn quartz veins, in which cassiterite and stannite were in equal proportions (INVERNO and RIBEIRO, 1980; INVERNO, 1980; INVERNO et al., 2009).

Renewed exploration by BTWP (20062010) involved lithogeochemistry of dumps and channel samples of trenches and un- derground drifts, assaying the former three deep drill-hole cores and drilling eight new shallow holes, 51-85 m long, collared at 526$608 \mathrm{~m}$ ASL and down to $454 \mathrm{~m}$ subsoil elevation. It was recognised that very fine Snand Li-bearing mineral phases also occurred in the host rocks of the Sn-Li quartz veins, The overall work enabled a pre-feasibility study relative to the $\mathrm{Sn}-\mathrm{Li}$ quartz veins of the shallowest part of the deposit. A resource of $9.3 \mathrm{Mt}$ at $0.2 \% \mathrm{Sn}, 0.2 \% \mathrm{Li}$ and $0.1 \%$ (estimate) $\mathrm{Rb}$ with a cutoff of $0.1 \%$ $\mathrm{Sn}$ and an additional resource of $10.8 \mathrm{Mt}$ at $0.07 \% \mathrm{Sn}, 0.2 \% \mathrm{Li}$ and $0.1 \%$ (estimate) $\mathrm{Rb}$ with a cutoff of $0.05 \% \mathrm{Sn}$ was inferred with an open pit operation in mind (FERRAZ et al., 2010). However, considering the continuity and grade of the Sn-Li mineralisation down to $0 \mathrm{~m}$ subsoil elevation as indicated by the deep drill-holes, it is estimated that this deposit may contain a total resource of over $200 \mathrm{Mt}$ at $0.1 \% \mathrm{Sn}(0.2 \% \mathrm{Sn}$ in the uppermost portions), $0.2 \% \mathrm{Li}$ and $0.1 \%$ (estimate) Rb (INVERNO et al., 2009), a figure that doubles a former estimate of $100,000 \mathrm{t}$ Sn (INVERNO, 1980).

In the current decade a shallow surface drilling campaign (all drill-holes $<100 \mathrm{~m}$ long) on the deposit and other additional exploration approaches have been carried out by the PANNN-Consultores de Geociências Lda., that confirmed the Sn-Li potential of the upper portion of the deposit. Recently PANNN applied to the Portuguese government agency for a permit to start an experimental stage of $\mathrm{Sn}$ and $\mathrm{Li}$ open pit mining operations at Argemela.

\section{Regional geology}

The Argemela deposit occurs in the Central Iberian Zone of the Iberian Massif (Fig. 
1). The deposit is hosted in the Cambrian Xistos das Beiras (Beiras Slates), a flysch sequence with slates, fine greywackes and some intraformational conglomerates. Ordovician quartzite ridges occur 15 and $23 \mathrm{~km}$ to the SW of Argemela. The deposit lies $2 \mathrm{~km}$ west of the zoned, pre-Variscan Fundão granitic pluton (Fig. 1), with granodiorites, quartz diorites and monzogranites, surrounded by a thermometamorphic halo of aluminous hornfels and spotted slates. To the north and south of this pluton there are biotite or twomica, porphyritic granite batholiths of Covilhã and Vale Prazeres - Castelo Branco, of late- to post-tectonic Variscan age, surrounded by thermometamorphic halos (Fig. 1) (INVERNO and RIBEIRO, 1980).

In general terms, the predominant Variscan granites in the Iberian Peninsula of Western Europe are the formerly so-called "Older" and "Younger" Granites of earliest late Carboniferous (320-310 Ma, U-Pb) and late Carboniferous (310-290 Ma, U-Pb) age, respectively (AZEVEDO et al., 2005; DIAS et al., 2006, 2016). The former are dominantly syn-tectonic (relative to $\mathrm{D}_{3} \mathrm{Va}$ riscan deformation phase) two-mica leucogranites and the "Younger" Granites are dominantly late- to post-tectonic (relative to Variscan $\mathrm{D}_{3}$ ) biotite granites, though either muscovite-bearing granite facies or porphyritic granite facies occur among both the "Older" and "Younger" granites. A crustal uplift started at $300 \mathrm{Ma}$, implying the rise of the ductile-fragile transition, caused the emplacement of the late- to post-tectonic (relative to $\mathrm{D}_{3}$ ) "Younger" Granites at relatively higher levels (MATEUS and NORONHA, 2010). Most Sn-W deposits are found associated with the "Younger" Granites (as in the Erzgebirge province; LEHMANN, 1990), interpreted as S-type granites, such as the Panasqueira W-Sn-Cu deposit (its granite: 289-290 $\pm 10 \mathrm{Ma}, \mathrm{K}-\mathrm{Ar}$; Kelly and Rye 1979), and only a few possibly with the "Older" Granites (SCHERMERHORN, 1982; OOSTEROM, 1988; GEOLOGICAL MAP OF PORTUGAL, scale 1:1 000 000, 2010).

The Sardian orogeny (in Cambrian time) developed regional NE-SW open folds with no axial plane cleavage (ROMÃO et al., 2013). The strongest Variscan deformation phase, $\mathrm{D}_{1}$, in Late Devonian - Early Carboniferous time, produced NW-SE folds with a steep axial plane cleavage and steep dipping axes due to superposition of folding and to the Variscan stretching of $\mathrm{D}_{1}$ deformation phase along the kinematic axis a (INVERNO and RIBEIRO, 1980; RIBEIRO and PEREIRA, 1982; DIAS et al., 2016). Near-horizontal tension fractures formed regionally perpendicular to this stretching. The Variscan regional metamorphism was in the chlorite zone of the greenschist facies (INVERNO and RIBEIRO, 1980).

The Argemela deposit is part of the W-E mineral lineament Góis-W(Sn) - Panasqueira-W(Sn) - Argemela-Sn, Li - Mata da Rainha-W(Sn) - Segura-W, Sn, Pb, $\mathrm{Zn}$ (Ba) (Fig. 1), close to the $40^{\circ}$ North parallel, suggesting a deep structural weakness zone (CARVALHO, 1977; INVERNO and RIBEIRO, 1980), characterized by regional E-W tensional fracturing during post-tectonic Variscan times (RIBEIRO and PEREIRA, 1982). Apart from the giant Panasqueira, these other regional "Younger" granite-related, Xistos das Beiras-hosted hydrothermal Sn-W quartz deposits are small, with past productions of a few hundred tonnes of wolframite and cassiterite concentrates for the vein-type Mata da Rainha and Segura deposits; the last being a com- 
posite deposit around the Segura "Younger" granite, with an inner lepidolite-montebrasite-cassiterite pegmatite vein zone, then a cassiterite-wolframite quartz vein zone and an outer zone with post-tectonic Variscan $\mathrm{Ba}-\mathrm{Pb}-\mathrm{Zn}$ quartz veins with past production of barite and galena concentrates (SIORMINP, 2002). Only Vale de Pião (Góis), with cassiterite-wolframite(-scheelite), is somewhat larger with resources of $0.5 \mathrm{Mt}$ with $0.2 \% \mathrm{Sn}$ and $0.2 \% \mathrm{WO}_{3}$ (PARRA, 1988) from its dominant hydraulic breccias and quartz vein (MARTINS, 2017).

\section{Local geology}

The flysch sequence of Xistos das Beiras is locally crosscut by dykes, recognised on the surface (Fig. 2), underground and in drill-holes. The dyke rocks present porphyritic to microlithic textures and, although not showing any internal foliation, are nevertheless quite deformed apparently due to the late-tectonic drive of the Variscan orogeny, with evidence of cataclasis, subgranulation and annealing. All dykes predate the mineralised Sn-Li quartz veins that transect them (INVERNO and RIBEIRO, 1980; INVERNO, 1998).

These dykes comprise: microgabbro dykes (Fig. 2), particularly a 2 m-wide, WNW-ESE-striking dyke locally known as Black Dyke; a $>5$ m-wide, NNE-SSWstriking quartz monzonite to lamprophyre dyke, with over $30 \%$ of biotite; and several 1.5-4 m-wide albitic microgranite dykes. The last are made up of up to $1 \mathrm{~cm}$-wide quartz phenocrysts in a groundmass of albite $\left(\mathrm{An}_{1}\right.$ $\mathrm{An}_{3}$ ), white mica (of phengitic composition; CHAROY and NORONHA, 1996) and rare biotite, with accessory cassiterite (in the groundmass [magmatic? cassiterite (ques- tioned by TAYLOR (1979) and LEHMANN (1990)] and in crosscutting quartz veinlets), rutile, amblygonite-montebrasite (in places abundant) and zircon. One of these albitic microgranite dykes is the 3-4 m-wide, NNESSW-striking dyke locally known as White Dyke (Fig. 2), that transects the Black Dyke (INVERNO and RIBEIRO, 1980; INVERNO, 1980). These albitic microgranite dykes have a high $\mathrm{Na} / \mathrm{K}$ atomic ratio (9-20), but are not very high in $\mathrm{SiO}_{2}(\approx \mathrm{wt}-70 \%)$, have rather low but anomalous concentrations of $\mathrm{P}_{2} \mathrm{O}_{5}(0.43$ wt \%), F (0.06-0.14 wt \%), Li (51$148 \mathrm{ppm})$ and $\mathrm{Sn}$ (77-174 ppm) (CHAROY and NORONHA, 1996), and are evolved specialised granitic rocks, as the last authors' reported high $\mathrm{Nb}$, Ta and REE and low $\mathrm{Zr}, \mathrm{TiO}_{2}, \mathrm{Sc}, \mathrm{Nb} / \mathrm{Ta}$ and $\mathrm{Zr} / \mathrm{Hf}$ values indicate (INVERNO and HUTCHINSON, 2006). They are distinct from S-type granites (INVERNO and RIBEIRO, 1980; INVERNO, 1998), being intermediate between those and I-type granites. It is one of the few cases in Portugal where tin mineralisation is not associated with typical S-type granites, another example being the outer facies of the Santa Eulália biotite granite massif in central Portugal (Inverno and Ribeiro 1980), ascribed to the magnetite-series granites (SANT'OVAIA et al., 2015).

One (or more) of these albitic microgranite dykes formed in a wider opening in the current Argemela hill top (some $500 \mathrm{~m}$ SE of Argemela mine workings) where an albitic microgranite is shown on the mine map (Fig. 2); after its emplacement this albitic microgranite was modified due to the subsequent building-up of volatiles, rare elements and $\mathrm{K}$ in the magmatic fluid from deeper portions causing the imprinting of a highly sodic and peraluminous second paragenesis, . The last contains quartz, albite, lepidolite, 
amblygonite-montebrasite, beryl and other minerals, and has chemical characteristics, but fails granularity of rare-element pegmatites (CHAROY and NORONHA, 1996; INVERNO, 1998). This Argemela hill-top evolved rare-metal albitic microgranite, thoroughly studied by CHAROY and NORONHA (1996), has a K-Ar age of $303 \pm 6$ Ma (NORONHA et al., 2013) - that is, affiliated with the "Younger" Granites -, is not surrounded by a thermometamorphic halo and shows the effects of moderate deformation when compared to the stronger deformation of the much narrower albitic microgranite dykes (INVERNO, 1998). Owing to the anomalously high Li content (0.2-1.0 wt \%; Jones 1972; CHAROY and NORONHA, 1996), this hill-top albitic microgranite is currently mined (in its $\mathrm{NE}$ end; Fig. 2) for applications in the ceramics industry. Tin is not recovered from this rock (0.06-0.08 wt \% Sn from a few analyses; CHAROY and NORONHA, 1996).

The $\mathrm{D}_{1}$ Variscan deformation phase produced folds displaying axial plane slaty cleavage in the Xistos das Beiras slates and pressure solution cleavage in the greywackes, both trending NW-SE and dipping $60-80^{\circ} \mathrm{SW}$. Late Variscan deformation produced near-vertical, perpendicular, N-S and E-W pressure solution crenulation cleavages in the Xistos das Beiras and might be the reason for the dykes internal deformation. Late Variscan tectonics resulted in strikeslip faults (DIAS et al., 2017), either rightlateral, NNE-SSW-striking or left-lateral, NE-SW to ENE-WSW-striking, both sets of which cutting the Black Dyke, the White Dyke (Fig. 2), and in places the Sn-Li mineralised veins (INVERNO and RIBEIRO, 1980; INVERNO, 1998).
As distinct from the spotted slates related to the Fundão massif, there are also two small portions of slightly spotted (biotite) slates in the area of the main mine workings (Fig. 2) related to an inferred hidden granitic cupola at depth. These slightly spotted slates become much more evident at depth. The possible hidden cupola at depth correlates with: a positive radiometric anomaly, up to $170 \mathrm{nGy} / \mathrm{h}$, in the area of the stockwork veins workings and immediately north of it (LNEG, 2013, internal radiometric maps, scales 1:500 000 and 1:200 000); and a cryptic circular structure in Argemela area identified in Landsat 2 images (CONDE and SANTARÉM, 1976; SANTARÉM, 1983).

\section{Characteristics and structural control of min- eralised veins}

After the main Variscan deformation, a stockwork quartz vein system formed, transecting all geological formations and bodies, but dominantly the Xistos das Beiras. These mineralised quartz veins are near-vertical, 5-30 $\mathrm{cm}$ thick, spaced $1 \mathrm{~m}$ apart, and have variable attitudes. The close spacing of the stockwork veins may be explained by their proximity to the hidden granitic cupola. They were mined from underground levels at 522, 566 and $599 \mathrm{~m}$ high, and also in opencasts and workings up to $650 \mathrm{~m}$ high, and were recognised, through deep drilling (down to $0 \mathrm{~m}$ subsoil elevation). The mineralised veins tend to be rarer to the east of the Black Dyke (microgabbro) suggesting that mineralising fluids invaded an area west of this dyke (Fig. 2) which would have been a barrier to the penetration of those fluids (INVERNO, 1980, 1998).

A detailed structural study showed that these veins dominantly infill tension 
fractures but a few occur in shear fractures (INVERNO and RIBEIRO, 1980). The vein orientations of the former have approximate radial distributions (Hosking 1959) converging in two centers, close to the richer Sn-zones, mineralised areas no. 1 and no. 2, defined by NORRIS (1962), but predominate around an E-W orientation (INVERNO and RIBEIRO, 1980). The subordinate shear-fracture veins have a more concentric distribution relative to those centers. It appears that at the time of vein formation two stress fields were operative. There was a regional stress field typical of a late Variscan deformation phase with maximum stress $\mathrm{s}_{1}$ as E-W (RIBEIRO and PEREIRA, 1982), that caused tension fractures with this attitude to open. A second stress field related to the intrusion of a granitic cupola (near-spherical prolate magma reservoir; KOIDE and BHATTACHARJI, 1975) at depth, produced radial tension fractures and more concentric shear fractures (Fig. 3; INVERNO and RIBEIRO, 1980; RIBEIRO and PEREIRA, 1982). Albitic microgranite dykes and apophyses were actually intersected by the deep drill-holes from 370 to 210 $\mathrm{m}$ subsoil elevation, in the area where the slightly spotted (biotite) slates were mapped on the surface (Fig. 4; INVERNO and RIBEIRO, 1980; INVERNO, 1998).

The Sn-Li quartz veins contain equal proportions of cassiterite and stannite as Sn ores, meaning that $75 \%$ of the recoverable tin is in cassiterite. Amblygonite-montebrasite, abundant in the veins, is the Li ore (INVERNO et al., 2009). However, some lithium is also contained in white mica. For instance, the white mica from albitic microgranite dykes has $0.40 \mathrm{wt} \% \mathrm{Li}_{2} \mathrm{O}$ and 1.32 wt \% F (CHAROY and NORONHA, 1996), comparable to $0.03-0.13$ wt $\% \mathrm{Li}_{2} \mathrm{O}$ and $0.05-0.80 \mathrm{wt} \% \mathrm{~F}$ in white mica from the Beauvoir granite, French Massif Central (with Sn-Li-Ta-Nb-Be mineralisation; CUNEY et al., 1992), but it can reach 4.60 wt $\% \mathrm{Li}_{2} \mathrm{O}$ and $5.81 \mathrm{wt} \% \mathrm{~F}$ in white mica from the Argemela hill-top modified albitic microgranite (CHAROY and NORONHA, 1996). The bulk of rubidium is in white mica (Inverno et al. 2009), that contains 0.251.23 wt $\% \mathrm{Rb}_{2} \mathrm{O}$ in the hill-top modified albitic microgranite, whereas its K-feldspar has 0.40-0.92 wt \% $\mathrm{Rb}_{2} \mathrm{O}$ (CHAROY and NORONHA, 1996).

\section{Sampling and analytical methods}

\section{Rock analyses}

Not only over 500 samples from outcrops, trenches, dumps and underground drifts and crosscuts (Level 1), but also continuous core samples from the deep SA-1, SA-2 and SA-3 (Fig. 4) drill-holes (949 samples) and from the eight recent BTWP shallow drill-holes (310 samples) were collected for analysis of potential ore metals at the LNEG Laboratory at S. Mamede de Infesta (Porto), Portugal. All samples were analysed for $\mathrm{Sn}$ (total), $\mathrm{Ta}, \mathrm{Nb}$ and $\mathrm{Rb}$ by XRF, with detection limits of 6,3 , 6 and 3 ppm (uncertainty $\leq 7 \%$ ), respectively, using a wavelength dispersive spectrometer (PW2404-PANalytical) equipped with a Rh tube $4000 \mathrm{~W}$. Results of elements analysed by XRF have a precision of $1 \%$ and an accuracy of better than $10 \%$. Additional analysed elements were $\mathrm{Li}, \mathrm{Cu}$ and $\mathrm{Ag}$ (only $20 \%$ of samples) by atomic absorption. Because the XRF calibration curve for $\mathrm{Rb}$ used at the LNEG laboratory was slightly off, $\mathrm{Rb}$ values may be up to $10 \%$ off the true values and therefore will be indicated as a simple estimate.

All samples that yielded Sn (total) con- 
centrations above 500 ppm were subsequently reanalysed for $\mathrm{Sn}$ (cassiterite) by chemical methods at the Panasqueira Mine laboratory, Barroca Grande (Covilhã, Portugal). There the samples were decomposed by hydrochloric and nitric acids. Filtration and calcination processes followed and the subsequent procedure involved the oxidation of stannous to stannic chloride in a hydrochloric acid solution. Finally, potassium iodate was used to determine Sn grade by a volumetric method.

\section{Petrography and micro-analytical techniques}

Some fifty polished thin sections were prepared from the three deep drill-hole cores for petrographic and paragenetic sequence studies, and microprobe analysis.

Quantitative analyses were performed on chlorite, amblygonite-montebrasite, cassiterite, sphalerite and stannite(-group minerals) using an electron microprobe JEOL JXA $-8500 \mathrm{~F}$ at the LNEG Laboratory at Porto. Operating conditions varied, from a $20 \mathrm{kV}$ excitation voltage and a $40 \mathrm{nA}$ beam current for cassiterite, to $20 \mathrm{kV}$ and $20 \mathrm{nA}$ for sphalerite and stannite, $15 \mathrm{kV}$ and $10 \mathrm{nA}$ for chlorite, and $15 \mathrm{kV}$ and $1 \mathrm{nA}$ for amblygonite-montebrasite analysis. The electron beam diameter was of $1 \mu \mathrm{m}$ for all minerals except for chlorite, for which a defocused 4 $\mu \mathrm{m}$ diameter beam was used and for amblygonite-montebrasite for which the diameter was $7 \mu \mathrm{m}$. Counting times varied from 20 to $60 \mathrm{~s}$. Chlorite was analysed for $\mathrm{Si}, \mathrm{Al}, \mathrm{Fe}, \mathrm{Ti}$, $\mathrm{Mg}, \mathrm{Mn}, \mathrm{Ba}, \mathrm{Ca}, \mathrm{K}, \mathrm{Na}, \mathrm{Cs}, \mathrm{Rb}, \mathrm{P}$ and F, amblygonite-montebrasite for $\mathrm{Na}, \mathrm{Al}, \mathrm{P}, \mathrm{Ca}$, $\mathrm{Fe}, \mathrm{Mn}$ and F, cassiterite for $\mathrm{Sn}, \mathrm{Si}, \mathrm{Ti}, \mathrm{Mn}$, $\mathrm{Fe}, \mathrm{Zr}, \mathrm{Nb}, \mathrm{Ta}, \mathrm{Bi}, \mathrm{Ag}, \mathrm{Cu}, \mathrm{Zn}, \mathrm{Pb}, \mathrm{Mo}, \mathrm{Sb}$, W, V, Co, As, Sc, In and Ge. Sphalerite and stannite were analysed for $\mathrm{S}, \mathrm{Fe}, \mathrm{Zn}, \mathrm{Cu}, \mathrm{Pb}$,
As, Hg, Cd, Se, In, Sb, Ag, Ge, Mn, Sn, W, $\mathrm{Bi}, \mathrm{Ni}$ and $\mathrm{Co}$. The elements, analytical lines and standards for the different elements in the analysed minerals are listed in Table 1.

\section{Fluid inclusions}

Fourteen doubly polished thin sections were prepared from core samples from deep drill-holes SA-1, SA-2 and SA-3, at about 170 through 390 m subsoil elevation. Microthermometric determinations were carried out successfully on about eighty fluid inclusions from eight of these doubly polished thin sections for fluid inclusions in quartz, carbonate, apatite and cassiterite from the mineralised Sn-Li quartz veins. Final icemelting $\left(\mathrm{T}_{\mathrm{m}}\right)$ and homogenisation temperatures $\left(T_{h}\right)$ were obtained with a Fluid Inc.adapted U.S.G.S. heating-freezing stage (SHEPERD et al., 1985).

Due to difficult visual conditions for these very fine inclusions, a cycling technique was used. Successive freezing runs to determine $\mathrm{T}_{\mathrm{m}}$ were taken at $0.5^{\circ} \mathrm{C}$ increasing increments and heating runs to determine $\mathrm{T}_{\mathrm{h}}$ at 5 or $10^{\circ} \mathrm{C}$ increments. A midpoint temperature between temperatures of two successive runs is indicated (see Table 4 in Fluid inclusion studies - Results section) both for the moment of disappearance of the last ice crystal $\left(\mathrm{T}_{\mathrm{m}}\right)$ or vapor bubble $\left(\mathrm{T}_{\mathrm{h}}\right)$ (GOLDSTEIN and REYNOLDS, 1994; INVERNO et al., 2008). The data are reported in that table for groups of primary inclusions, fluid inclusion assemblages (FIAs) in different growth zones of the crystal and in few cases for isolated inclusions within those zones. The accuracy of the thermocouple was estimated at $\pm 0.1^{\circ} \mathrm{C}$ from the recommended value for standards, and the maximum variation of replicate determinations was $\pm 0.1^{\circ} \mathrm{C}$. 
A crushing stage was used to investigate possible gases, if any, in the inclusions under study. Raman spectroscopic analysis was additionally used for the same purpose. Fluid inclusions of one of the quartz samples were analysed (through WITec) in Lisbon (Portugal) with a Confocal Raman microscope, carrying an Apyron tube (from WITec) and a PI stage, under a beam of $350 \mathrm{~nm}$ in diameter.

\section{Vein mineralogy and paragenetic sequence}

The mineralised stockwork veins (Fig. $5 \mathrm{~A}$ ) are made up mostly of quartz, amblygonite-montebrasite, cassiterite, stannite, white mica, pyrite, chalcopyrite, arsenopyrite and pyrrhotite. No correlation was found between vein thickness and mineralogy. In the mine area, the rocks hosting the veins, mostly slate and greywacke, contain rather widespread tourmaline, particularly in the more pelitic layers, as well as very fine disseminations of cassiterite, also occurring in minute fissures (JONES, 1972; INVERNO and RIBEIRO, 1980); the same host rocks are also enriched in $\mathrm{Li}$ and $\mathrm{Rb}$, both elements mostly incorporated in fine-grained white mica (FERRAZ et al., 2010).

The albitic microgranite dykes contain microveinlets $(1-10 \mathrm{~mm})$ and veinlets (1-2 $\mathrm{cm}$ thick) of quartz, white mica, sulphides (pyrrhotite, and more rarely arsenopyrite, pyrite and chalcopyrite) and in places amblygonite (or montebrasite; CHAROY and NORONHA, 1996) that predate the Argemela Sn-Li stockwork quartz veins also hosted in these dykes.

\section{Stage I}

The earliest mineral deposited in the Argemela stockwork veins was a milky white to greenish (to bluish) variety of the amblygonite-montebrasite series (Fig. 5B), which in places almost fills the entire vein. Amblygonite-montebrasite grains range from $75 \mu \mathrm{m}$ to more common $3 \mathrm{~cm}$ wide, with abundant simple and lamellar twinning $\{\overline{11} 1\}$ (Fig. 5C) and common $\{100\}$ and $\{110\}$ cleavage traces. In quartz veins in albitic microgranite dykes, amblygonite-montebrasite also occurs in anhedral to subhedral grains, generally in the upper part of the $75 \mu \mathrm{m}-7.5 \mathrm{~mm}$ width range.

\section{Stage II}

Amblygonite-montebrasite was followed in the stockwork veins by the two main quartz generations: 1) anhedral (to subhedral) quartz $\mathrm{I}$, with grains from $50 \mu \mathrm{m}$ but mostly up to $2.5 \mathrm{~cm}$ wide, commonly with sutured boundaries or subgranulation along those boundaries, and commonly packed with mostly secondary fluid inclusions; and 2) anhedral to euhedral, rarely deformed, finer-grained (50 $\mu \mathrm{m}-2.5 \mathrm{~mm})$ quartz II, with fewer fluid inclusions (Fig. 5D), which is intimately associated with Sn ore. Most of the succeeding paragenetic opaque and transparent minerals (Table 2) commonly deposited in the transition from amblygonite-montebrasite to quartz I - quartz II.

Quartz I and II were succeeded by anhedral to euhedral, mostly light-brown, 10 $\mu \mathrm{m}-7.5 \mathrm{~mm}$ (mostly $<1 \mathrm{~mm}$ )-wide cassiterite grains, generally forming aggregates up to $1.3 \mathrm{~cm}$ wide (Fig. $5 \mathrm{E}, \mathrm{H}-\mathrm{I}$ ), and up to 3 $\mathrm{cm}$ wide in albitic microgranite dykes (Fig. $5 \mathrm{G})$. The cassiterite has growth twins $\{101\}$, "visor tin" ( $\{011\}$ twins), common internal zoning (Fig. 5F), with yellow, green, orange, but mostly red internal reflections, and 1-75 $\mu \mathrm{m}$-wide anhedral columbite-tantalite 
inclusions (Fig. 5J). This is Fe-columbite contrasting Mn-columbite disseminations in the hill-top modified albitic microgranite (CHAROY and NORONHA, 1996; MICHAUD et al., 2017). Quartz I and II and cassiterite are transected by fine-grained (25-100 $\mu \mathrm{m}$ wide) white mica I ("sericite") (Table 2). Anhedral (to subhedral), very fine- to medium-grained (rare clusters up to $5 \mathrm{~mm}$ wide) arsenopyrite I, that transects quartz I and II, forms about the same time as cassiterite, and in places shows dendritic textures

Very small platelets of chlorite I, making up aggregates up to $4.5 \mathrm{~mm}$ wide, replace and rim amblygonite and also invade quartz I. Rare fine- to coarse-grained (granularity scale used: very fine-grained, $<10 \mu \mathrm{m}$; finegrained, 10-100 $\mu \mathrm{m}$; medium-grained, 100$1,000 \mu \mathrm{m}$; and coarse-grained, $>1,000 \mu \mathrm{m}$ ) subhedral, microveinlet-hosted fluorite transects quartz I and II and is altered to white mica ("sericite"). Euhedral and anhedral, fine- to medium-grained apatite, with abundant fluid inclusions, occurs in close association with cassiterite, postdating it. Carbonate I, that mostly postdates quartz I and II (Table 2), occurs in fine to coarse, anhedral to euhedral crystals (Fig. 6A). The latter (up to $2.4 \mathrm{~mm}$ wide) are in places part of vein walls, with crystal terminations pointing into the vein centre, characteristic of openspace growth. They contain abundant fluid inclusions. Anhedral, very fine- to mediumgrained rutile occurs in association with white mica I (Table 2), either in the quartz veins or their walls or, more commonly, in the host slates; in places it may also occur in quartz veinlets in albitic microgranite dykes. The Al-phosphates augelite and lazulite identified by GASPAR (1991) possibly belong to this Stage II as well.

\section{Stage III}

Subsequent to white mica I forms white mica II (Table 2), typically as lamellae from $10 \mu \mathrm{m}$ to $3 \mathrm{~mm}$ long and aggregates up to $1 \mathrm{~cm}$ wide, in places with a radial pattern. White mica is very common adjacent to the internal walls in quartz veins and generally increases in abundance in these veins with depth. Early-formed carbonate I was subsequently recrystallised into euhedral to anhedral, fine- to medium-grained carbonate II (Table 2), that forms microveinlets which transect sulphides (e.g., stannite, chalcopyrite). The carbonate, either I or II, is mostly ferroan dolomite and siderite.

Tourmaline cuts or is cut by white mica II. It comes with a light brown (dravite?) to dark (schorl?) color, in euhedral and more rarely anhedral, fine to coarse grains, making clusters up to $1 \mathrm{~cm}$ wide when in quartz (micro)veinlets, but being fine- to mediumgrained, and much more abundant in the external slate walls of those veinlets, where this hydrothermal tourmaline (LONDON and MANNING, 1995) crystals typically grow either perpendicular or, even more, parallel to the walls. Both chalcopyrite and pyrite transect tourmaline there. In addition to amblygonite-montebrasite, a medium-grained, bluish Li mineral, triphylite (confirmed by XRD), occurs rarely, apparently displaying multiple twins (or after all from an alteration product of triphylite: sinkankasite(?), a Mn phosphate; PEACOR et al., 1984), and forming microveinlets that transect white mica II. Quartz III, that occurs in late microveinlets, is anhedral to subhedral, varies in diameter from 50 to $500 \mu \mathrm{m}$ (in places optically continuous quartz III may persist for up to $3.5 \mathrm{~mm}$ along the microveinlets) and generally contains few fluid inclusions. 
Molybdenite was one of the earliest sulphide minerals to form but is quite rare. It is found in the slate-hosted quartz veins and in quartz veinlets in albitic microgranite dikes, is fine-grained and occurs as aggregates up to $2.4 \mathrm{~mm}$ wide, that postdate white mica I, but were contemporaneous to white mica II. Sphalerite, stannite, and chalcopyrite occur together and were generally deposited in the order listed, although crosscutting relationships indicate that locally the order was partly or completely reversed (Table 2). Stannite is the most abundant of these minerals (Fig. $5 \mathrm{H}-\mathrm{I})$, though a chalcopyrite-rich zone was detected above and external to the extensive Sn-rich zone. Stannite grains are anhedral (to subhedral), $2 \mu \mathrm{m}-4.4 \mathrm{~mm}$ wide, and form aggregates up to $2 \mathrm{~cm}$ wide. In places they display $\{111\}$ twins or a colloform texture; elsewhere the grains are subgranulated and may also form very fine $(<1 \mu \mathrm{m})$ inclusions in sphalerite. Stannite rims cassiterite (Figure 5I), cuts quartz I and II, white mica I and commonly white mica II and also postdates chlorite I; quartz III microveinlets that crosscut cassiterite grains carry stannite, together with pyrrhotite and chalcocite. Very fine- to coarse-grained, anhedral stannite in quartz veins in albitic microgranite dykes is transected by white mica lamellae. The term stannite has been used here, in microscopic descriptions, as a simplification for stannitegroup minerals, since stannite, kesterite and ferrokesterite are all abundant (see microprobe data section).

Two varieties of anhedral sphalerite are present. They formed penecontemporaneously, but are never observed in contact with each other. A brown (macroscopically; green in plane-polarized light), very fine- to coarse-grained (with aggregates up to $3 \mathrm{~mm}$ wide) variety of sphalerite, dis- playing chalcopyrite (and stannite) disease, formed in the lower and intermediate parts of the deposit, The second variety, which is darker (red in plane-polarized light), formed in the upper parts of the deposit. It is fineto coarse-grained (with up to $10 \mathrm{~mm}$-wide clusters), and shows no evidence of chalcopyrite disease. Sphalerite rims and crosscuts cassiterite (Fig. 5H-I) and is transected by white mica II. Anhedral, fine- to mediumgrained sphalerite also occurs in quartz veins in albitic microgranite dykes. Anhedral, very fine- to coarse-grained chalcopyrite (it forms clusters up to $3.8 \mathrm{~mm}$ wide) crosscuts cassiterite, and generally postdates sphalerite and stannite (Fig. 5H-I). It forms 1-30 $\mu \mathrm{m}$-wide inclusions in sphalerite variety deeper in the deposit (Fig. $5 \mathrm{H}$ ). Very fine- to medium-grained, anhedral chalcopyrite may also be present in quartz veins in albitic microgranite dykes.

Anhedral (to euhedral) very fine- to medium-grained pyrite occurs sparsely in the slate-hosted quartz veins, as disseminations (in places coarse-grained) in the slates and in quartz veins in albitic microgranite dykes. In the former, it may in places take the form of very fine-grained (2-5 $\mu \mathrm{m}$-wide) "primitive" pyrite, occasionally recrystallised to $15 \mu \mathrm{m}$ wide grains, all forming 0.1-1.4 mm-wide brain-like or regular aggregates; colloform textures are also in places recognised. Pyrite transects quartz I and II and carbonate II(?), rims sphalerite, and is a component of the quartz III microveinlets (with stannite and other minerals) that crosscut cassiterite.

Arsenopyrite II, more widespread than arsenopyrite I, is euhedral (or more rarely anhedral), very fine- to coarse-grained (mostly $>150 \mu \mathrm{m}$ wide), and forms aggregates up to $2.3 \mathrm{~mm}$, either in quartz III microveinlets or in disseminations in the 
slates (where it is in places more abundant), transects tourmaline, cuts or is more rarely cut by white mica II, and postdates pyrite. Closely following pyrite is relatively rare anhedral, very fine- to medium-grained (clusters up to $175 \mu \mathrm{m}$ wide) pyrrhotite, associated with sphalerite, chalcopyrite and stannite; it postdates the last two minerals. Pyrrhotite is accompanied by anhedral, very fine- to fine-grained chalcocite, that develops caries texture in this iron sulfide. Both minerals plus stannite are carried by quartz III microveinlets that transect cassiterite.

Chlorite II is a late mineral (Table 2), comprising fine platelets and aggregates (up to $7.7 \mathrm{~mm}$ in diameter). It is either an alteration product of white mica II or occurs in microveinlets transecting several sulphide grains.

\section{Stage IV}

Supergene anhedral, very fine- to finegrained (aggregates $\leq 125 \mu \mathrm{m}$ wide) covellite in places replaced chalcopyrite or more rarely chalcocite. Submillimetric, near-parallel to the mineralised quartz vein walls, commonly slate-hosted veinlets or microveinlets of a relatively abundant, dark blue iron phosphate in Argemela, vivianite (with 50$90 \mu \mathrm{m}$-wide fibers), identified both optically and by XRD, are also a product of supergene processes. The same holds true for very late goethite or lepidocrocite microveinlets that formed throughout the deposit (Table 2). Other supergene minerals were reported as occurring in places in the Sn-Li quartz veins, wavellite (GASPAR, 1991) and turquoise (DE CARVALHO and HAMILTON, 2017).

\section{Fluid inclusion studies}

\section{General}

Fifty polished thin sections and fourteen doubly polished thin sections were examined and scanned for fluid inclusions in quartz I, quartz II, carbonate I, apatite and cassiterite (Stage II) and sphalerite (Stage III) from the $\mathrm{Sn}-\mathrm{Li}$ stockwork quartz veins. Sphalerite is almost devoid of visible fluid inclusions and was discarded after this initial survey. Only Stage II minerals were studied, because transparent minerals from other stages were not amenable to fluid inclusion work due to containing very rare inclusions (e.g., quartz III and carbonate II from Stage III).

The main purpose was to locate primary or at least pseudosecondary fluid inclusions, for subsequent microthermometric determinations. No particular emphasis was focused on secondary inclusions during microthermometry and only locally were determinations carried out on them.

Evident pseudosecondary fluid inclusions are rare (only recognised in quartz II) and large fluid inclusions randomly distributed within the cores of crystals (inclusions of doubtful primary origin; BODNAR, 2003) are absent. However, quartz I and II, carbonate I and apatite crystals contain easily recognisable growth zones with abundant primary fluid inclusions and cassiterite growth bands contain a few primary fluid inclusions as well.

In cases of primary inclusions along growth zones or bands in apatite and cassiterite, respectively (Tables 3 and 4), in which those inclusions are in the proximity of microfissures with secondary inclusions, those inclusions are marked with $\mathrm{P}($ ?) in Table 4. Also, because of possible coincidence of 
growth zones with cleavage planes in carbonates (ROEDDER, 1984), these cases are also marked with $\mathrm{P}($ ?) in Table 4.

\section{RESULTS}

The main petrographic characteristics, involving genetic type, fluid inclusion assemblage (FIA), inclusion type, size, shape, V/L (vapour to liquid volumetric) consistency and $\mathrm{V} / \mathrm{T}$ (vapour to total inclusion volumetric) ratios of the fluid inclusions of quartz I (Fig. 6A, C-D), quartz II (Fig. 6B), carbonate I, apatite (Fig. 6E-I), and cassiterite (Figs. 5F, 6J-K) from Stage II are summarized in Table 3. Primary inclusions in all these minerals are very minute and dominantly aqueous.

In any of these minerals (e.g., quartz I), the presence of $\mathrm{L}+\mathrm{V}$ and $\mathrm{V}$ inclusions in the same growth zone indicates that necking occurred at least locally. Additional liquid-only inclusions formed by necking in the same growth zone and absence of either growth zones with only vapor-rich inclusions or of microfractures containing only vapor-rich inclusions suggest that boiling did not occur (BODNAR et al., 1985).

The primary aqueous fluid inclusions, where determinations could be conducted, from slate-hosted mineralised veins, yield salinities and homogenisation temperatures $\left(\mathrm{T}_{\mathrm{h}}\right)$, the former calculated from final icemelting temperatures $\left(\mathrm{T}_{\mathrm{m}}\right)$ using the equation of BODNAR (1993). Salinity and $T_{h}$ values obtained for these primary inclusions are of 7.2-13.9 wt \% $\mathrm{NaCl}$ equiv. and $290-340^{\circ} \mathrm{C}$ for quartz I, 8.6-13.9 wt $\% \mathrm{NaCl}$ equiv. and $310-320^{\circ} \mathrm{C}$ for carbonate I, 8.615.0 wt $\% \mathrm{NaCl}$ equiv. and $330-350^{\circ} \mathrm{C}$ for apatite, and 12.9-19.1 wt \% $\mathrm{NaCl}$ equiv. and $300-360^{\circ} \mathrm{C}$ for cassiterite (Table 4; Fig. 7).
Homogenisation occurs through disappearance of the inclusion vapor bubble. Determinations in quartz II primary inclusions were not successful.

No significant variation in both salinity and homogenisation temperature exists vertically in the mineralised stockwork quartz veins. Cassiterite data, relative to the more widespread sample location (from 171 to $390 \mathrm{~m}$ of subsoil elevation) documents this particularly well (Table 4).

No halite or other daughter crystals were detected in the primary inclusions inspected in these different minerals, as the moderately saline values of these $\mathrm{NaCl}$-undersaturated- $\mathrm{H}_{2} \mathrm{O}$ primary inclusion fluids indicate. In very few cases where halite was suspected, heating of those inclusions to very high temperatures proved that was not the case (no fading out, no melting of the hypothesized "halite"). The use of a crushing stage showed that neither $\mathrm{CO}_{2}$ nor $\mathrm{CH}_{4}$ were present in these primary inclusions. This was confirmed with Raman spectroscopic analysis of primary fluid inclusions in growth zones in quartz I (sample SA1-5). Differing from the stockwork vein minerals, these gases were found in fluid inclusions in quartz from the hill-top modified albitic microgranite (CHAROY and NORONHA, 1996).

\section{Rock analyses}

A total of 1759 rock samples (mostly 0.6$1.8 \mathrm{~m}$ intervals) from surface, Level 1 and core down to $0 \mathrm{~m}$ subsoil elevation (from the three deep drill-holes and the eight BTWP shallow drill-holes) shows very persistent analytical results, with average $0.1 \%(0.2 \%$ in upper portions) $\mathrm{Sn}, 0.2 \% \mathrm{Li}$ and $0.1 \% \mathrm{Rb}$ (estimate) throughout (Fig. 8; median val- 
ues of $0.2 \% \mathrm{Sn}$ and $0.15 \% \mathrm{Li}$ in cumulative percentage plots). The persistency of those grades is due to a close and regular vein density and to the continuity of the mineralised veins to a very great depth. Maximal values in metric intervals are of $4.1 \% \mathrm{Sn}, 1.8 \% \mathrm{Li}$ and $0.4 \% \mathrm{Rb}$ (estimate) (FERRAZ et al., 2010).

Copper values are low, all below $0.1 \mathrm{wt}$ $\% \mathrm{Cu}$, but when the mineralised veins are more prominent they reach up to 1.6 (and in one case 4.6) wt \% $\mathrm{Cu}$ in 3 per cent of the metric samples. Niobium values are also low, mostly below $30 \mathrm{ppm} \mathrm{Nb}$, with only $6 \%$ of the samples up to 261 and in two samples 696 and 956 ppm Nb; tantalum concentrations are even lower, mostly below the detection limit $(<5 \mathrm{ppm} \mathrm{Ta})$, with only $7 \%$ of the metric samples up to $141 \mathrm{ppm}$ Ta. Higher $\mathrm{Na}$ and $\mathrm{Ta}$ values are either for samples of albitic microgranite dykes or not. Silver values are mostly below the detection limit $(<3 \mathrm{~g} / \mathrm{t} \mathrm{Ag})$, but in one third of the samples analysed for silver they reach up to 100 $\mathrm{g} / \mathrm{t} \mathrm{Ag}$ and in three cases, 118, 159 and 660 $\mathrm{g} / \mathrm{t} \mathrm{Ag}$. A good match was found between Sn (cassiterite) results and the little higher Sn (total) results (FERRAZ, 2007, 2008a, 2008b; FERRAZ et al., 2010)

The Beira Slates (slates and a few greywackes) hosting the $\mathrm{Sn}-\mathrm{Li}$ quartz veins yield $\mathrm{Sn}$ values at least one order of magnitude lower than those of the veins, with $\mathrm{Sn}$ carried in very fine/fine cassiterite disseminations in the slates (INVERNO and RIBEIRO, 1980; FERRAZ, 2008a). The same Beira Slates contain rock-forming, fine-grained (20-75 $\mu \mathrm{m}), \mathrm{Li}$ - and Rb-bearing white mica (FERRAZ, 2008a). The Li concentrations are similar in Sn-Li quartz veins and host slates, except when those veins contain $\geq 10 \%$ amblygonite-montebrasite yielding the rock $0.5-1.8 \mathrm{wt} \% \mathrm{Li}$. The $\mathrm{Rb}$ concentrations in Sn-Li quartz veins, $<0.1$ wt \% Rb, are generally lower than in the adjacent host slates (FERRAZ, 2007).

The relatively lower number of $\mathrm{Sn}-\mathrm{Li}$ quartz veins hosted in albitic microgranite dykes have $\mathrm{Sn}$ and $\mathrm{Li}$ values similar or one order of magnitude higher than the host microgranite. The last has $\mathrm{Li}$ and $\mathrm{Rb}$ concentrations one order of magnitude lower than the Beira Slates (FERRAZ, 2007). Only the hill-top modified albitic microgranite reaches higher values, $0.55 \mathrm{wt} \% \mathrm{Li}$ and $0.24 \mathrm{wt}$ $\%$ Rb (CHAROY and NORONHA, 1996).

Geochemical concentrations in the Beira Slates further away (up to $10 \mathrm{~km}$ ) from the Argemela deposit decrease in one order of magnitude for $\mathrm{Li}, \mathrm{Rb}, \mathrm{Cu}$ and $\mathrm{Nb}$, with $\mathrm{Sn}$ and $\mathrm{Ag}$ being in irrelevant below detection limit concentrations immediately off the deposit area (FERRAZ, 2008a).

\section{Microprobe data}

\section{Cassiterite}

Microanalyses of cassiterite from the slate-hosted quartz(-amblygonite-montebrasite) veins and from quartz-amblygonite-montebrasite-white mica veinlets in an albitic microgranite dyke were carried out. High values of $1.95 \mathrm{wt} \% \mathrm{Nb}, 0.39 \mathrm{wt} \% \mathrm{Fe}$, 0.13 wt $\%$ Ti (up to 2.10 wt $\% \mathrm{Nb}, 0.72$ wt $\%$ $\mathrm{Fe}, 0.32 \mathrm{wt} \% \mathrm{Ti}$ in veinlet in albitic microgranite dyke) and low/negligible values for base metals, Sb, As, Ag and Bi, among other elements, were obtained. $\mathrm{W}$ and $\mathrm{Zr}$ values are erratic, but reach $0.33 \mathrm{wt} \%$ and $0.05 \mathrm{wt}$ $\%$, respectively. Mn values are low, at most 0.01 wt \% (Table 5).

Most cassiterite grains have higher concentrations of $\mathrm{Fe}, \mathrm{Nb}$ and $\mathrm{Ta}$ in rims than 
in cores, but the opposite occurs in cassiterite from the quartz-amblygonite-white mica veinlets in an albitic microgranite dyke. Fe, $\mathrm{Nb}$, $\mathrm{Ta}$ and $\mathrm{Zr}$ concentrations (and $\mathrm{Ta} / \mathrm{Nb}$ ratios) in cassiterite generally increase to depth, as approaching the postulated granite cupola, but $\mathrm{Ti}$ concentrations remain similar; for all these elements the highest values are commonly obtained in cassiterite from the quartz-amblygonite-montebrasitewhite mica veinlets in an albitic microgranite dyke (Table 5).

\section{Sphalerite and stannite}

Coexisting sphalerite and stannite(group minerals) (Table 2) from the slate-hosted quartz stockwork veins were analysed in the electron microprobe. Fe-poor sphalerite, from lower and intermediate deposit portions, contains 31.7-33.4 wt \% S, 1.0-1.6 wt $\% \mathrm{Fe}, 64.3-66.0$ wt $\% \mathrm{Zn}$ and $0.4-0.5 \mathrm{wt}$ $\% \mathrm{Cd}$, while $\mathrm{Fe}$-rich sphalerite, from upper portions has 32.4-33.4 wt \% S, 7.9-9.4 wt \% $\mathrm{Fe}, 55.9-57.2 \mathrm{wt} \% \mathrm{Zn}$ and 0.9-1.1 wt \% Cd, the remaining trace elements being equivalent in both varieties (Table 6).

Kesterite and ferrokesterite coexist with Fe-poor sphalerite and stannite coexists with $\mathrm{Fe}$-rich sphalerite. Besides values for $\mathrm{S}$, $\mathrm{Fe}, \mathrm{Zn}, \mathrm{Sn}$ and $\mathrm{Cu}$, all the trace elemental concentrations are very similar for the three stannite-group minerals (Table 7).

\section{Amblygonite-montebrasite}

The mineral of the amblygonite-montebrasite series was analysed in specimens from the Sn-Li quartz veins, either hosted in the slates or in the albitic microgranite dykes. The analysed mineral is montebrasite, as formerly recognised (GASPAR, 1991), with a percentage of amblygonite of 7-20\% (Table 8). The proportion of amblygonite in the mineral slightly increases to depth, with $\%$ amblygonite of 9-13 (corresponding to $1.2-1.8 \mathrm{wt} \% \mathrm{~F})$ and $12-19(1.6-2.4 \mathrm{wt} \%$ F) at 310 and $255 \mathrm{~m}$ subsoil elevation, both in slate-hosted vein samples (samples SA1-2 and SA1-6, respectively); albitic microgranite-hosted mineralised quartz veinlets at 229 $\mathrm{m}$ subsoil elevation (sample SA1-8) have more erratic fluorine values in the montebrasite (0.9-2.3 wt \% F), corresponding to a percentage of amblygonite of 7-18\%. It is also apparent a slight increase in these numbers from the no. 1 mineralised area to the no. 2 mineralised area (south of the former; Figures 2 and 4) of NORRIS (1962), with the analysed mineral containing 1.8-2.6 wt $\% \mathrm{~F}$, corresponding to $14-20 \%$ amblygonite, at $255 \mathrm{~m}$ subsoil elevation (sample SA2-5a) in the latter (Table 8).

The $\mathrm{Na}_{2} \mathrm{O}$ concentration is low in the mineral (0.00-0.08 wt \%), very far behind typical values of natromontebrasite and natroamblygonite (PALACHE et al., 1951). The $\mathrm{FeO}$ and $\mathrm{MnO}$ concentrations are low, commonly in the 0.00-0.14 and 0.00-0.25 wt $\%$ ranges, respectively, but reach up to 0.44 wt $\% \mathrm{FeO}$ and $0.34 \mathrm{wt} \% \mathrm{MnO}$ in montebrasite from the microgranite dyke-hosted mineralised quartz veinlets (Table 8 ).

\section{Chlorite}

A few microanalyses were conducted on a $400 \mu \mathrm{m}$-wide chlorite (I?) alteration halo rimming amblygonite in stockwork quartz veinlets hosted in a microgranite dyke, from specimen SA1-8. This chlorite is moderately enriched in iron (23.6-26.7 wt \% FeO), poor in magnesium (1.1-1.2 wt \% MgO), but with a high 22.7-24.8 wt $\% \mathrm{Al}_{2} \mathrm{O}_{3}$. It also contains 0.001-0.05 wt \% $\mathrm{Cs}_{2} \mathrm{O}, 0.01-0.12$ wt \% $\mathrm{BaO}$, and in places $0.02 \mathrm{wt} \% \mathrm{~F}$ (Table 9). This 
chlorite from alteration of amblygonite is also likely to contain a few per cent of $\mathrm{Li}_{2} \mathrm{O}$, and the system is otherwise rich in lithium; triphylite occurs in the quartz veins and white mica is enriched in $\mathrm{Li}$ for instance in the albitic microgranite dykes $\left(0.40 \% \mathrm{Li}_{2} \mathrm{O}\right)$ and in the Argemela hill-top albitic microgranite (up to $4.6 \mathrm{wt} \% \mathrm{Li}_{2} \mathrm{O}$; $\mathrm{CHAROY}$ and NORONHA, 1996). Furthermore, as the total of cations in the octahedral position of chlorite is far lower than 12 (Table 9), there is room to accommodate other unanalysed cations there.

This tri-octahedral chlorite plots as $\mathrm{Al}$ chlorite in the triangular $\left(\mathrm{Al}^{\mathrm{VI}}+\mathrm{o}\right)-\mathrm{Fe}-\mathrm{Mg}$ classification of ZANE and WEISS (1998), and can also be termed as aluminian chamosite in the condensed terminology of BAYLISS (1975) and BAILEY (1980).

\section{Discussion}

\section{Rock analyses}

The large extent of the deposit, with persistent low grade mineralisation (Fig. 8), indicates that a large amount of fluid has escaped from the underlying granite cupola but not much high grade mineralisation produced. This may be due to fluid- versus rock-buffering conditions (see subsequent heading on Reaction of fluid and precipitation).

On the other hand, the fine granularity of rock-forming white mica carrying $\mathrm{Li}$ and $\mathrm{Rb}$ in the Beira Slates host rocks implies that $\mathrm{Li}$ and $\mathrm{Rb}$ are not economically recoverable from those rocks. Together with the very fine cassiterite disseminations in the host slates in the deposit area, this means that not all $\mathrm{Sn}$ and $\mathrm{Li}$ in the system are recoverable in the mill, but only that from the Sn-Li quartz veins. A pilot test conducted at the LNEG Laboratory at Porto showed that only 50\% of $\mathrm{Sn}$ was recovered during mineral processing operations due part of the metal being allocated in the host shales (FERRAZ et al., 2010).

There is some parallelism between geochemical concentrations in host rocks and further away from the Argemela deposit and what happens in Panasqueira, where the hydrothermally altered Beira Slates hosting the quartz W-Sn-Cu veins are characterized by $\mathrm{K}_{2} \mathrm{O} / \mathrm{Rb}(\mathrm{wt} / \mathrm{wt})<250$ and are enriched in $\mathrm{Rb}, \mathrm{K}, \mathrm{Cs}, \mathrm{Li}, \mathrm{W}, \mathrm{Cu}, \mathrm{Zn}, \mathrm{Sn}, \mathrm{S}$ and $\mathrm{P}$ relative to unaltered Beira Slates (BUSSINK, 1984; OOSTEROM et al., 1984; POLYA, 1989). The mean W, Cu and Sn concentrations decrease irregularly away from the Panasqueira cupola, with anomalous concentrations up to about $10 \mathrm{~km}$ away from it (POLYA, 1989).

\section{Mineral chemistry}

\section{Cassiterite}

The high concentrations of $\mathrm{Nb}, \mathrm{Fe}$ and $\mathrm{Ti}$ and low/negligible concentrations of As, $\mathrm{Sb}, \mathrm{Zn}, \mathrm{Ag}$ and $\mathrm{Bi}$ in cassiterite from Argemela Sn-Li quartz veins are proper of granite affiliation (DUDYKINA, 1959; STEVESON and TAYLOR, 1973; NEIVA, 1996).

The very high $\mathrm{Nb}$ values in cassiterite resemble those of pegmatitic cassiterite, but the overall set of data for the several elements points in this case to inclusion of the Sn mineral in granite-affiliated quartzcassiterite hydrothermal veins. The same is confirmed by the extremely low Mn concentrations, typical of those sorts of veins but not of pegmatitic cassiterite that has higher Mn values (HALL and RIBBE, 1971; NEI- 
VA, 1996). The relatively high $\mathrm{W}$ values in the analysed cassiterites (Table 5) are also characteristic of those hydrothermal veins (TAYLOR, 1979).

The increase in $\mathrm{Fe}, \mathrm{Nb}$, Ta and $\mathrm{Zr}$ concentrations in cassiterite in quartz veins towards the postulated granite at depth agrees well with higher concentrations for these elements in veins in the albitic microgranite dykes rooted in such a granite. Also, the vertical variation of the $\mathrm{Ta} / \mathrm{Nb}$ ratio in cassiterite in slate-hosted quartz veins, with increase to depth, with the deepest sample matching the values obtained in cassiterite from a quartz vein in a microgranite dyke, suggest magmatic differentiation (CERNÝ, 1991a). An identical Ta/Nb ratio variation was obtained in cassiterite from the Khingan deposit (Baikal, C.E.I.) in a rhyolite - quartz porphyries setting intruded by a granite porphyry (NIKULIN, 1969; MATERIKOV, 1977).

\section{Sphalerite and stannite(-group minerals)}

The presence of Fe-rich sphalerite versus Fe-poor sphalerite in upper and intermediate/lower portions, respectively, of the Argemela deposit may be due to the fact that mole fraction of $\mathrm{FeS}$ in sphalerite increases with decreasing pressure (LUSK and FORD, 1978) or more probably to a variation in oxygen and/or sulfur fugacities (see Temperature-Pressure conditions).

\section{Amblygonite-montebrasite}

A decrease in fluorine in zoned amblygonite-montebrasite crystals from Siberia was suggested as due to lower crystallisation temperature for the montebrasite (CERNÁ et al., 1972), though GROAT et al. (2003) claim, based on neutron diffraction and solid-state techniques, that for this series the temperature dependence of $\mathrm{Li}$ is the same regardless of $\mathrm{F}$ concentration. However, LONDON et al. (1999) admitted, after experimental work, that amblygonite is more stable than montebrasite at a higher temperature. The slight increase in F concentration in amblygonite-montebrasite in the Argemela Sn-Li quartz veins to depth might also be a consequence of higher temperature formation of the mineral at lower deposit portions. CHAROY and NORONHA (1996) also pointed out the decrease in $\mathrm{F}$ concentration in amblygonite-montebrasite from the hill-top albitic microgranite to its crosscutting quartz veinlets (their low $\mathrm{F}$ montebrasite also analysed by RODA-ROBLES et al. (2016)) and even more to the crosscutting quartz veinlets in albitic microgranite dykes. Montebrasite in the Argemela $\mathrm{Sn}-\mathrm{Li}$ quartz veins has minor variations in the $\mathrm{F} / \mathrm{OH}$ ratio, with a range of $1.18-2.60$ wt $\% \mathrm{~F}$ (Table 8), much below that of Li-rich pegmatites (RODA-ROBLES et al., 2016).

A slight deficiency in $\mathrm{Al}_{2} \mathrm{O}_{3}$ in a few of the analytical results (Table 8) might be due to alteration (ANTUNES et al., 2010). Ü

\section{Temperature - Pressure conditions}

\section{Stage II}

The determined salinities of 7.2-13.9, 8.6-13.9, 8.6-15.0 and 12.9-19.1 wt \% NaCl equiv and $\mathrm{T}_{h}$ of 290-340, 310-320, 330-350 and $300-360^{\circ} \mathrm{C}$ for primary inclusions in quartz I, carbonate I, apatite and cassiterite (Stage II), respectively, from slate-hosted veins, show that the depositional fluids were moderately saline and at a temperature proper of a magmatic-hydrothermal system 
- e.g., Eurajoki (Finland) Sn greisen veins (HAAPALA and KINNUNEN, 1979); Kibaran (Central Africa) tin deposits (POHL and GÜNTHER, 1991). These depositional conditions are not very dissimilar from those of the rather nearby Panasqueira W$\mathrm{Cu}-\mathrm{Sn}$ deposit where the main ore (oxidesilicate, sulphides and pyrrhotite alteration stages) deposited from fluids at $230-360^{\circ} \mathrm{C}$, with a salinity of $5-12$ wt $\% \mathrm{NaCl}$ equiv. and generally with $0.5-2$ (4) mole- $\% \mathrm{CO}_{2}$ (KELLY and RYE, 1979; POLYA, 1989; NORONHA et al., 1992). The $\mathrm{CO}_{2}$, not detected in the primary inclusions of Argemela stockwork minerals, was interpreted at Panasqueira as derived from the Beira Slates hosting the deposit (KELLY and RYE, 1979; SHEPPARD, 1986).

A binary diagram of homogenisation temperature versus salinity for the Argemela primary inclusion fluids produces a roughly linear trend (Fig. 9), suggesting that fluid mixing (of probable magmatic fluids) was an important process leading to deposition.

The absence of significant vertical variation in these fluids along a few hundred meters in subsoil elevation is also compatible with such a system above a granitic cupola, particularly in a not very shallow geological environment.

For this dense stockwork vein system (related to a hidden granitic cupola) of a deposit located in a regional deep E-W weakness zone $\left(\mathrm{s}_{1}, \mathrm{E}-\mathrm{W}\right)$, with the veins filling dominant pervasive near-vertical tension fractures to great depth, a hydrostatic pressure has to be considered. As an estimated 4-5 $\mathrm{km}$ of cover rock were removed by erosion (see CHAROY and NORONHA, 1996), this would imply a hydrostatic pressure about $50 \mathrm{MPa}$, which corresponds, for the above salinities, to a pressure correction of about $40^{\circ} \mathrm{C}$ (POTTER II, 1977; POTTER II and BROWN, 1977; ROEDDER and BODNAR, 1980), to get trapping temperatures.

\section{Stage III}

For Stage III, the sphalerite-stannite(group minerals) electron microprobe pairs of data (Table 10) allow the use of equations reporting dependency of $\mathrm{Fe}$ and $\mathrm{Zn}$ partitioning between sphalerite and one of the stannite-group minerals. A temperature range of $141-220^{\circ} \mathrm{C}$ was obtained for coexisting sphalerite and stannite(-group minerals) from Argemela quartz veins using the equation of NEKRASOV et al. (1979), whereas that of NAKAMURA and SHIMA (1982), usually taken as more reliable (Sinclair et al. 2006), permits to calculate a temperature range of $245-297^{\circ} \mathrm{C}$ (Table 10). This is slightly lower but not very dissimilar from in equilibrium sphalerite-stannite temperatures from the granite-related Changpo $\mathrm{Sn}-\mathrm{Cu}$ deposit in the Dachang district, Guangxi, China (LATTANZI et al., 1989).

The use of the same NAKAMURA and SHIMA's (1982) equation also indicates that Fe-rich sphalerite formed at 256$284^{\circ} \mathrm{C}$, and $\mathrm{Fe}$-poor sphalerite at $245-297^{\circ} \mathrm{C}$ (Table 10). There is a slight tendency for the Fe-rich sphalerite temperature values to be among some of the highest temperature values obtained with this geothermometer. But Fe-poor sphalerite temperature values can be equally high or lower, meaning that the range of temperatures is so similar for both sphalerite varieties that inferences are difficult to draw. The same holds true for the stannite(-group minerals) of each pair, having in mind that stannite and kesterite are known to form in the same temperature 
range (SPRINGER, 1972; KISSIN, 1989).

However, in general the mole- $\% \mathrm{FeS}$ in sphalerite is, at a given temperature, only a function of $\mathrm{a}_{\mathrm{FeS}}$, inversely related to $\mathrm{aS}_{2}$ (SCOTT and KISSIN, 1973; DEER et al., 1992), what is confirmed by the SHIMIZU and SHIKAZONO's (1985) temperature$\log \mathrm{aS}_{2}\left(-\mathrm{X}_{\mathrm{Fe}}^{\mathrm{sp}}\right)$ diagram. This would imply that Fe-poor sphalerite formed at a higher $\mathrm{aS}_{2}$ than Fe-rich sphalerite, though at an equivalent temperature (see Depositional conditions).

Based on the chlorite microprobe data (Table 9), the use of the KRANIDIOTIS and MACLEAN's (1987) geothermomether, that takes into account not only $\mathrm{Al}^{\mathrm{IV}}$ but also $\mathrm{Fe}$ and $\mathrm{Mg}$ cationic proportions, enables to determine a formation temperature range of $166-187^{\circ} \mathrm{C}$ for the chlorite (I?).

\section{Depositional conditions}

As indicated from the textural relationship (Table 2), amblygonite-montebrasite was undoubtedly the first mineral to deposit in the Sn-Li quartz veins. Unlike the commonly known formation temperatures of amblygonite-montebrasite in pegmatites (over a temperature range of $500-700^{\circ} \mathrm{C}$; SHIGLEY and BROWN, JR., 1985), not much is known on the formation temperature of amblygonite-montebrasite in hydrothermal veins. All that can be stated for the case of Argemela quartz veins is that amblygonite-montebrasite formed earlier than quartz (Table 2), as the system was cooling from deposition of initial amblygonite-montebrasite to later quartz, cassiterite and other minerals for which $\mathrm{T}_{\mathrm{h}}$ and trapping temperatures were determined. This shift from amblygonite-montebrasite (Stage I) to quartz, cassiterte and the other Stage
II minerals deposition might correspond to a switch from an alkaline pulse to an acidic pulse in the magmatic(-hydrothermal) fluids (oral communication from JOHN WALSHE, CSIRO-Australia, 2017).

Given the overall homogenisation temperatures, for quartz I, carbonate I, apatite and cassiterite, in the $290-360^{\circ} \mathrm{C}$ range and the deduced pressure correction of $40^{\circ} \mathrm{C}$, this results in an estimated granitic cupola-related hydrothermal mineralisation mean temperature of $₫ 350^{\circ} \mathrm{C}$ in a hydrostatic system at a fluid pressure of $50 \mathrm{MPa}$, common in other granite-related tin deposits (WRIGHT and KWAK, 1989; REN et al., 1995). Additionally, as the depositional fluid had an overall salinity of 7.2-19.1 wt \% $\mathrm{NaCl}$ equiv. (1.61- $4.04 \mathrm{~m} \mathrm{NaCl}$ solution), calculation of the corresponding total $\mathrm{a}_{\mathrm{Cl}}$ of $0.19-0.33 \mathrm{~m}$ at $350^{\circ} \mathrm{C}$ sustains an intermediate value for $\mathrm{a}_{\mathrm{Cl}}{ }^{-}$of $0.25 \mathrm{~m}$ as a good estimate.

For such a fluid, under prevailing acidic conditions since early deposition, as the early genesis of "sericite" (white mica I) and chlorite I (Table 2) testify (see HEINRICH and EADINGTON, 1986), the dominant $\mathrm{Sn}$ complexes would be the Sn chloride complexes, (HEINRICH, 1990; TAYLOR and WALL, 1993). Actually, though rare fluorite postdated cassiterite during deposition (Table 2), the widespread abundant amblygonite-montebrasite deposited earlier than cassiterite in the quartz $\mathrm{Sn}$ veins, and its buffering effect implies that fluoride could not have significantly influenced $\mathrm{Sn}$ solubility immediately prior to and during cassiterite deposition. Under these conditions, the dominant Sn complex, at quite reducing conditions, in between the quartzfayalite-magnetite (QFM) and the $\mathrm{Ni}-\mathrm{NiO}$ (NNO) buffers (close to the latter), is dis- 
puted between $\mathrm{SnCl}_{2}{ }^{\circ}$ and $\mathrm{SnCl}_{3}^{+}$(and even $\mathrm{SnCl}^{+}$) for different authors (EADINGTON and GIBLIN, 1979; PATTERSON et al., 1981; EADINGTON, 1983; JACKSON and HELGESON, 1985a; PABALAN, 1986; DUBESSY et al., 1987; WILSON and EUGSTER, 1990; LEHMANN, 1990; TAYLOR and WALL, 1993; MÜLLER and SEWARD, 2001; MIGDISOV and WILLIAMS-JONES, 2005). Anyway, they are the two predominant transporting $\mathrm{Sn}$ complexes under the mentioned conditions (JACKSON and HELGESON, 1985a; MÜLLER and SEWARD, 2001), including an $\mathrm{a}_{\mathrm{Cl}}$ of $0.25 \mathrm{~m}$ and a temperature of $350^{\circ} \mathrm{C}$.

Under these conditions and assuming an activity of $\Sigma \mathrm{S}$ of $0.01 \mathrm{~m}$ (estimated from: BARNES, 1979; POLYA, 1989), thermodynamic calculations enabled to build a $\mathrm{fO}_{2}-\mathrm{pH}$ diagram relative to the system $\mathrm{Sn}-\mathrm{S}-\mathrm{O}$, superimposed on the system $\mathrm{Fe}-\mathrm{S}-\mathrm{O}$, and taking into account the sulfur-containing aqueous species. Boundaries for the Sn oxide and sulphide phases and the $\mathrm{Fe}$ oxide and sulphide phases, plus sulphur aqueous species, are plotted in Figure 10, together with solubility contours for the sum of activities of $\mathrm{SnCl}_{2}{ }^{\circ}$ and $\mathrm{SnCl}_{3}{ }^{+}$representing total $\mathrm{Sn}$ solubility. Cassiterite would have precipitated according to the deposition arrow (Fig. 10), from hydrothermal solutions about $350^{\circ} \mathrm{C}$ with an activity of $10^{-4}$ to $10^{-3} \mathrm{~m} \mathrm{Sn}$, corresponding to a concentration of roughly 10-100 ppm $\mathrm{Sn}$ in solution, at a $\mathrm{pH}$ of 3.5-4 and an oxygen fugacity of $10^{-34}$ to $10^{-32} \mathrm{~atm}$. The depositional conditions are consistent with the presence of pyrite, but not of pyrrhotite, rare in this deposit, and hardly of haematite, magnetite and simple Sn sulphides (herzenbergite, ottemanite and berndtite), all absent in Argemela (Table 2; Fig. 10)). The depositional conditions are not very dissimi- lar from either those of Panasqueira main ore-stage fluids $\left(230-360^{\circ} \mathrm{C}, 1-2 \mathrm{~m} \mathrm{NaCl}\right.$ equiv., $\Sigma \mathrm{S}=10^{-2.5}, \mathrm{pH}=5-6, \mathrm{fO}_{2}=10^{-32}$ to $10^{-}$ 34.5; KELLY and RYE, 1979; POLYA, 1989; NORONHA et al., 1992) or of many other granite-related tin deposits formed at $350^{\circ} \mathrm{C}$ (PATTERSON et al., 1981; JACKSON and HELGESON, 1985b; HEINRICH and EADINGTON, 1986; REN et al., 1995).

Therefore, cassiterite precipitation (under both rock- and fluid-buffered conditions) in Stage II in Argemela, due to the destabilisation of Sn chloride ion complexes, was caused by at least a $\mathrm{pH}$ increase of the hydrothermal fluid, oxidation and possible increase in $\mathrm{a}_{\mathrm{Cl}}$, together with cooling (and decreasing pressure), as expressed by the reaction (in this case using only one of the $\mathrm{Sn}$ complexes)

$\mathrm{SnCl}_{2}{ }^{\circ}+2 \mathrm{H}_{2} \mathrm{O}=\mathrm{SnO}_{2}+2 \mathrm{H}^{+}+2 \mathrm{Cl}^{-}+\mathrm{H}_{2}{ }^{\circ}$ (HEINRICH, 1990)

as in other granite-related $\mathrm{Sn}$ deposits (EUGSTER and WILSON, 1985; PABALAN, 1986; HALTER et al., 1996, 1998; LINNEN, 1998; INVERNO and HUTCHINSON, 2004; WAGNER et al., 2009). As some arsenopyrite I deposited together with cassiterite (Table 2), the favoured and more specific equilibrium under fluid-buffered conditions would be expressed by

$$
\begin{aligned}
& 3 \mathrm{SnCl}_{2}{ }^{\circ}+2 \mathrm{H}_{3} \mathrm{AsO}_{3}{ }^{\circ}+2 \mathrm{FeCl}_{2}{ }^{\circ}+2 \mathrm{H}_{2} \mathrm{~S}^{\circ}= \\
& 3 \mathrm{SnO}_{2}+2 \mathrm{FeAsS}+10 \mathrm{Cl}^{-}+10 \mathrm{H}^{+} \\
& (\mathrm{HEINRICH} \text { and EADINGTON, 1986) }
\end{aligned}
$$

The lower temperature of Stage III stannite $\left(247-297^{\circ} \mathrm{C}\right)$ relative to cassiterite deposition, as in sulphides from other granite-related Sn deposits (REN et al., 1995), suggests, together with the paragenetic se- 
quence (Table 2), that stannite in Argemela deposited at a late stage of the hydrothermal system that changed from dominant $\mathrm{Sn}$ chloride complexes (during cassiterite deposition) to $\mathrm{Sn}$ ions precipitating as sulphides, as stannite, at a lower $\mathrm{fO}_{2}$ than cassiterite (EADINGTON and GIBLIN, 1979; JACKSON and HELGESON, 1985b).

Also, the occurrence of stannite, together with pyrrhotite in quartz III veinlets transecting cassiterite grains equally suggests low sulphur fugacities (PATTERSON et al., 1981) during stannite deposition. Calculation of $\mathrm{FeS}$ activities based on mole- $\% \mathrm{FeS}$ in sphalerite (1.8-2.9 and 14.2-16.9 mole- $\%$ $\mathrm{FeS}$ in $\mathrm{Fe}$-poor and $\mathrm{Fe}$-rich varieties, respectively; Table 5) yields (CRAIG and SCOTT, 1974) $\mathrm{a}_{\mathrm{FeS}}$ of 0.05-0.07 and 0.34-0.39 for Fe-poor and Fe-rich sphalerite, respectively, corresponding (on using diagram in Fig. 7.7 of BARTON and SKINNER (1967)) to a $\mathrm{fS}_{2}$ of $10^{-9.4}$ to $10^{-11.6}$ and $10^{-11.7}$ to $10^{-13.0}$ atm, respectively. This confirms former approaches in this paper, here showing that, though formed at the same temperature range, Fe-rich sphalerite known at the shallower portions of Argemela formed at a lower sulphur fugacity than Fe-poor sphalerite, from the deeper parts of the deposit. This may not be due properly to pressure, since only a few hundred meters separate the above-mentioned parts of the deposit, but to a variation in oxygen fugacity; when higher it favoured the deposition of Fe-rich sphalerite.

\section{Ore system model}

\section{Reaction of fluid and precipitation}

Mixing between an intrusion-derived fluid (magmatic condensed brine), even in a minor proportion (HEINRICH, 1990), and surrounding, low-salinity, meteoric waters played an important role in the formation of other granite-related Sn deposits (KELLY and RYE, 1979 [Panasqueira W-Sn deposit]; HEINRICH and EADINGTON, 1986; HEINRICH, 1990; REN et al., 1995; AUDÉTAT et al., 2000, 2008; MÜLLER et al., 2001; LU et al., 2003; WAGNER et al., 2009). This is unlike the Silsilah Sn deposit, Saudi Arabia, where the lack of a significant admixture of meteoric water into the system appears as one of the possible main reasons that made it not a major, but only an economically marginal $\mathrm{Sn}$ deposit (KAMILLI and CRISS, 1996). It should also be stressed that a $\mathrm{H}_{2} \mathrm{O}$-dominated fluid phase was suggested (Charoy and Noronha 1996) for the late fluid evolution associated with the Argemela hill-top modified albitic microgranite, but there is no evidence of meteoric water in the Argemela Sn-Li veins. However Fig. 9 suggests that some mixing occurred. Actually at Argemela the magmatic-hydrothermal moderate-salinity fluid (primary inclusions) could possibly result from mixing of high-salinity magmatic fluids and low-salinity magmatic fluids exsolved late in the lifetime of the magmatic-hydrothermal system; this could also explain the relative spread of salinities (7.2-19.1 wt \% $\mathrm{NaCl}$ equiv.) obtained. Both high and low salinity magmatic fluids coexist in other tin deposits of this type, e.g. a few of the Cornwall (England) tin deposits (SHEPERD and MILLER, 1988) and of the Erzgebirge province (STEMPROK, 1984).

The relatively low Sn and Li grade of the veins might be, on the other hand, not due to a complete (but only incomplete) fluid-buffered cooling of the magmatic fluid (in isolation from host rock), and also to its partial 
rock-buffered cooling (in equilibrium with host rock) [HEINRICH, 1990]. This is consistent with the abundance in Argemela SnLi quartz veins of arsenopyrite I deposited together with cassiterite (Table 2) through the dominant reaction (1) versus the relatively more widespread arsenopyrite II (following pyrite), characteristic of fluid-buffered versus rock-buffered (near the Ni-NiO buffer) cooling paths, respectively. These paths would be under lower (below the Ni-NiO buffer) and higher oxygen fugacities (near the same buffer), respectively (HEINRICH and EADINGTON, 1986). The rare pyrrhotite in Argemela quartz $\mathrm{Sn}-\mathrm{Li}$ veins is also explained by the higher oxygen fugacity of a rock-buffered cooling path favouring deposition of pyrite, relatively more abundant in the veins, as the Fe sulphide.

The rock-buffered component of the cooling process would also explain the relatively high $\mathrm{Sn}$ and $\mathrm{Li}$ contents from disseminations in the host rocks to the Sn-Li veins. Lower $\mathrm{Sn}$ grades are known to be concentrated in the ore shoots ( $\mathrm{Sn}$-Li quartz veins in this case) when this process prevails (HEINRICH, 1990). This may explain why in Argemela a large amount of fluid escaped from the inferred granitic cupola, as the persistent $\mathrm{Sn}$ and Li concentrations from rock analyses in the overall system testimony, but not much high grade mineralisation was produced.

\section{Source of metal rich fluid and intrusion age}

Either a differentiate of the Variscan late- to post-tectonic, either two-mica or biotite granites Covilhã batholith or an inferred granitic body at depth at Argemela (CHAROY and NORONHA, 1996) intruded into the Xistos das Beiras succession. The latter hypothesis is more probable due to the $\mathrm{K}-\mathrm{Ar}$ age of the modified hill-top albitic microgranite, $303 \pm 6 \mathrm{Ma}$, confining it to the mid period of the Variscan late- to posttectonic granites interval age. As there was a time span to modify the hill-top albitic microgranite, that explains why the albitic microgranite dykes related to the hidden granite are internally strongly deformed, before the elsewhere emplacement of the Variscan post-tectonic granites, commonly at 299-290 Ma [U-Pb] (DIAS et al., 2006).

Albitic microgranite dykes are associated with the inferred granite cupola at depth. If these dykes represent a trace of the hidden granite, then this is an evolved metallogenetically specialised granitic rock, carrying cassiterite and amblygonite-montebrasite among other minerals.

At Argemela, the main mineralogical and chemical characteristics of the hidden granite, as represented by its albitic microgranite dykes, can be explained by a strong fractionation of a Sn-, F- and Li-rich magma and associated fluid phases. As an additional source of the metal rich fluid, some pre-concentration of at least very fine cassiterite in the Xistos das Beiras shales was described by INVERNO and RIBEIRO (1980) that admitted that it could also have been involved/remobilised by the hidden granite intrusion of late tectonic Variscan age.

The extreme fractionation of a F-, Li-, $\mathrm{P}$ - and other volatiles-rich granitic magma would be responsible for the development of the second paragenesis (albite, ambligonitemontebrasite then lepidolite) with chemical pegmatitic affinities imprinted on the earlier hill-top albitic microgranite (albite, muscovite) (CHAROY and NORONHA, 1996). However, no true (complex) pegmatites 
formed possibly because depth was insufficient. CHAROY and NORONHA (1996) suggest a pressure somewhat above $150 \mathrm{MPa}$ during the formation of the second paragenesis of the hill-top modified albitic microgranite, which is low as compared to those of LCT pegmatites development ( 200-400 MPa; CERNÝ, 1991b).

The dense hydrothermal Sn-Li quartz vein system postdated the albitic microgranite dykes and probably also the second paragenesis of the hill-top modified albitic microgranite. The Sn-Li quartz veins are claimed by CHAROY and NORONHA (1996) as not being genetically linked to the hill-top modified microgranite, in consonance with RIBEIRO et al. (1974) and INVERNO and RIBEIRO (1980), but in both cases probably related to a common parental intrusion at depth (CHAROY and NORONHA, 1996). In any case the overall system was very enriched in $\mathrm{F}, \mathrm{P}$ and $\mathrm{Li}$ (also reflected in the extent of the metassomatically induced Li in the Beira Slates away from the deposit) and, under those circumstances, when $\mathrm{Sn}-\mathrm{Li}$ veins started to develop, amblygonite-montebrasite was the first mineral to deposit, even before and at a higher temperature than quartz and cassiterite; the last depositing from Cl-rich mineralising fluids. This may explain why the Argemela hydrothermal quartz tin veins are so enriched in amblygonite-montebrasite, a mineral commonly known from complex pegmatites.

In general terms, from an overall granite melt, F and Li were extracted at the magmatic stage and the onset of the high temperature postmagmatic hydrothermal stage and Sn was extracted subsequently, altogether in a modelling way in this respect similar to the development in the Beauvoir granite in France (CUNEY et al., 1992). The hidden granite (and its melt) responsible for the $\mathrm{Sn}-\mathrm{Li}$ vein swarm were the source of $\mathrm{F}, \mathrm{Li}$, $\mathrm{P}$ (and most $\mathrm{Sn}$ ), contrasting that of Panasqueira where $\mathrm{B}$ had a major role (CHAROY and NORONHA, 1996), as evidenced by the widespread tourmaline deposited in the Panasqueira W-Sn-Cu quartz veins and enclosing slates (KELLY and RYE, 1979), clearly more abundant than in the Argemela $\mathrm{Sn}-\mathrm{Li}$ quartz veins and wall rocks. This implies different fluids produced at the end of crystallisation of (or slightly after) the Argemela granitic magma compared to the Panasqueira one (CHAROY and NORONHA, 1996).

\section{Evolution, deformation and structure focus- ing}

The Xistos das Beiras were deformed first by the Sardian phase of the Caledonian orogeny and later by the main deformation phase $\left(D_{1}\right)$ of the Variscan orogeny with development of a NW-SE-striking slaty cleavage and in association with low pressure regional metamorphism. In late- to postorogenic (relative to $\mathrm{D}_{3}$ ) Variscan time there was emplacement of a granite cupola and its albitic microgranite dykes, having the granite thermally metamorphosed the Xistos das Beiras rocks.

The albitic microgranite dykes emerging from the hidden granite contain a faint (micro)veinlet generation of quartz-white mica-sulphides \pm amblygonite-montebrasite. These dykes as well as other dykes (microgabbro and quartz-monzonite to lamprophyre) in the area were internally deformed by the Variscan late tectonic pulses. A local evolution of the albitic microgranite dykes occurred in the current Argemela hill top where the paragenesis (quartz-albite- 
white mica) of one or more of these dikes was overprinted, due to volatile and rareelement ( $\mathrm{Li}, \mathrm{F}, \mathrm{P}, \mathrm{Rb}, \mathrm{Cs}, \mathrm{Be}, \mathrm{Sn}, \mathrm{Nb}$, Ta, etc.) fluids emerging from the granite, by a second paragenesis containing quartz, albite, lepidolite, amblygonite-montebrasite, cassiterite and other minerals. This second paragenesis (aged $303 \pm 6 \mathrm{Ma}$; K-Ar) has the mineralogical and chemical characteristics, but not the granularity of rare-element pegmatites (CHAROY and NORONHA, 1996; INVERNO, 1998).

The emplacement of the hidden granite cupola led to the opening in the overlying slates of abundant dominant radial fractures (and minor more concentric shear fractures) that together with regional E-W tension fractures made the system change from lithostatic to hydrostatic pressure conditions. A dense network of both types of fractures was infilled by the quartz Sn-Li veins, with early deposition of amblygonitemontebrasite, followed by quartz, cassiterite and white mica, and stannite and sulphides later on. This overall deposition, on one hand probably succeeded shortly the timing of formation of the second paragenesis of the hill top modified microgranite and on the other hand occurred later than the aforementioned internal microveinlet generation of the albitic microgranite dykes, which were crosscut, as well as the slates, by the quartz $\mathrm{Sn}-\mathrm{Li}$ veins. In Variscan post-tectonic times a system of NNE-SSW to ENE-WSW extensive wrench faults displaced all dykes in the area, the hill-top modified albitic microgranite, and also the Sn-Li quartz veins.

With the exception of the "pegmatoidal" second paragenesis of the hill top modified albitic microgranite and the abundance of amblygonite-montebrasite in the $\mathrm{Sn}-\mathrm{Li}$ quartz veins, the general lithologic-tecton- ic-magmatic-hydrothermal evolution of the Argemela area and deposit is in general terms not very dissimilar from that of the Panasqueira deposit (THADEU, 1951; KELLY, 1977; KELLY and RYE, 1979).

\section{The uniqueness of Argemela Sn-Li quartz veins}

Other than in LCT pegmatites, lithium is also enriched in hydrothermal quartz veins associated with leucogranites in the central parts of the Central Iberian Zone such as Golpejas, Valdeflores and Barquilla in Spain and Massueime in Portugal, the Li mineral being montebrasite and with cassiterite and $\mathrm{Nb}$-Ta oxides commonly present (RODAROBLES et al., 2016). But, among these hydrothermal quartz veins, what is striking in Argemela is that these veins are equally enriched in Sn and Li there.

Together with other hydrothermal quartz-montebrasite veins in Central Iberian Zone, the Argemela Sn-Li quartz veins show lower degrees of fractionation than Li-rich (LCT) pegmatites in the region and were formed in a later hydrothermal stage (RODA-ROBLES et al., 2016).

According to CERNÝ and ERCIT (2005), the crystallisation of montebrasite requires a high $\mu \mathrm{PFO}_{2}$. The high concentrations of $\mathrm{P}$ could be explained by the fractionation of $\mathrm{P}$ as an incompatible element from peraluminous perphosphorous melts. The fact that mafic components in the original melt were scarce would not favour the formation of Fe-Mn phosphates, but would instead enrich $\mathrm{P}$ in the melt from which montebrasite crystallised (RODA-ROBLES et al., 2016), as in Argemela Sn-Li quartz veins. 


\section{CONCLUSIONS}

Research on a rather unusual hydrothermal stockwork vein assemblage, with dominant quartz and amblygonite-montebrasite, together with cassiterite, stannite and white mica in Argemela Sn-Li deposit, hosted in Cambrian flysch rocks, overlying and related to a hidden granitic cupola, yielded salinities and homogenisation temperature ranges of 7.2-19.1 wt $\% \mathrm{NaCl}$ equiv. and $290-360^{\circ} \mathrm{C}$ for primary aqueous fluid inclusions in quartz I, carbonate I, apatite and cassiterite (Stage II). Considering pressure correction, a mean temperature of $350^{\circ} \mathrm{C}$ at a fluid pressure of $50 \mathrm{MPa}$ was set for the depositional hydrothermal fluids after early formation of amblygonite-montebrasite at a higher temperature (Stage I).

Minor and trace elemental concentrations of its quartz vein cassiterite, with high values of $\mathrm{Nb}, \mathrm{Fe}$ and $\mathrm{Ti}$ and low/negligible values of $\mathrm{Sb}, \mathrm{Zn}, \mathrm{As}, \mathrm{Ag}$ and $\mathrm{Bi}$ are typical of hydrothermal quartz-cassiterite veins of granitic affiliation. Deposition of cassiterite would have occurred due to probable admixture of high salinity and low salinity magmatic-hydrothermal fluids, from Sn chloride complexes, with a calculated $\mathrm{a}_{\mathrm{Cl}}=0.25 \mathrm{~m}$, at a $\mathrm{fO}_{2}$ of $10^{-34}$ to $10^{-32}$ atm and a $\mathrm{pH}$ of 3.5 to 4. Mechanisms of cassiterite deposition were mixing, oxidation, neutralisation, possible increase in $\mathrm{a}_{\mathrm{Cl}-}$, together with cooling (and decreasing pressure).

Subsequent deposition (Stage III) in the same veins of coexisting and in equilibrium sphalerite and stannite(-group minerals) occurred at $245-297^{\circ} \mathrm{C}$. Sphalerite mole$\% \mathrm{FeS}$ enables to calculate a higher $\mathrm{fS}_{2}$ for formation of Fe-poor sphalerite (plus kesterite/ferrokesterite) from intermediate and lower parts of the deposit than that of $\mathrm{Fe}$ - rich sphalerite (plus stannite) from the upper part of the deposit, the latter probably formed at a higher $\mathrm{fO}_{2}$.

The continuity of this unusual graniterelated, high-tonnage, low-grade $\mathrm{Sn}-\mathrm{Li}$ Argemela deposit from $650 \mathrm{~m}$ high to $0 \mathrm{~m}$ subsoil elevation and the persistence of $\mathrm{Sn}$ and $\mathrm{Li}$ grades throughout indicates that it may have the size of a porphyry-type deposit, though unequivocally of a different genetic type. The unusual high abundance of amblygonite-montebrasite, not common in other hydrothermal quartz tin veins may be due to an extreme fractionated $\mathrm{F}$-, $\mathrm{Li}$ and P-rich granitic magma leading to the emplacement of the (hidden) granite and its albitic microgranite dykes. An emerging pegmatitic fluid was unable, possibly due to insufficient depth, to form pegmatites, but only modified an albitic microgranite on the Argemela hill top, developing a volatilerich second paragenesis. In any case and as a consequence, the system, where mixing between high- and low-salinity magmatic fluids probably occurred, remained very enriched in $\mathrm{F}, \mathrm{Li}$ and $\mathrm{P}$ and when the succeeding hydrothermal stockwork developed amblygonite-montebrasite was the first mineral to deposit abundantly before quartzcassiterite stage deposition in those Argemela Sn-Li quartz veins.

\section{Acknowledgements}

Delfim de Carvalho, António Ribeiro and Luís Viegas, all from Portuguese government agencies, are thanked for guiding early studies of this deposit. T. James Reynolds (FLUID INC., Denver) is acknowledged for guidance in a few fluid inclusion work problems. We are grateful to Alexandra Barreiro (LNEG) for laboratory facilities. Though 
partly disagreeing with him, we thank Fernando Noronha (Univ. Porto) for his criticisms on the Argemela study matters. Daniel de Oliveira (LNEG) is thanked for improving the English. The authors thank the Boards of Directors from LNEG and BTWP for allowing the publication of this paper.

\section{ORCID}

Carlos Inverno https://orcid.org/00000002-0806-5330

\section{REFERENCES}

ANTUNES, I.M.H.R., NEIVA, A.M.R., SILVA, M.M.V.G. and SILVA, P.B. (2010). Mineralogy of Li-bearing granitic aplite-pegmatite veins from Segura. In: Neiva, J.M.C., Ribeiro, A., Victor, M., Noronha, F. and Ramalho M., eds., Ciências Geológicas - Ensino e Investigação e sua História. Associação Portuguesa de Geólogos - Sociedade Geológica de Portugal, v. I, cap. 1 (Cristalografia e Mineralogia), p. 3-14.

AUDÉTAT, A., GÜNTHER, D. and HEINRICH, C.A. (2000). Causes for large-scale metal zoning around mineralized plutons: Fluid inclusion LA-ICPMS evidence for the Mole Granite, Australia. Economic Geology, 95:1563-1581.

AUDÉTAT, A., PETTKE, T., HEINRICH, C.A. and BODNAR, R.J. (2008). The composition of magmatic-hydrothermal fluids in barren and mineralized intrusions, Economic Geology, 103:877-908.

AZEVEDO, M.R., AGUADO, B.V., NOLAN, J., MARTINS, M.E. and MEDINA, J. (2005). Origin and emplacement of syn-orogenic Variscan granitoids in Iberia: the Beiras massif. Journal of the
Virtual Explorer (electronic edition), 19:1-17.

BAILEY, S.W. (1980). Summary of recommendations of the AIPEA Nomenclature Committee. Canadian Mineralogist, 18:143-150.

BARNES, H.L. (1979). Solubilities of ore minerals. In: Barnes, H.L., ed., Geochemistry of hydrothermal ore deposits, $2^{\text {nd }}$ ed. New York (NY), John Wiley \& Sons, p. 404-460.

BARTON, P.B., JR. and SKINNER, S.D. (1967). Sulfide mineral stabilities. In: Barnes. H.L., ed., Geochemistry of hydrothermal ore deposits, $1^{\text {st }}$ ed. New York (NY), Holt, Rinehart and Winston Inc., p. 236-333.

BAUMANN, L. (1970). Tin deposits of the Erzgebirge. Institution of Mining and Metallurgy Transactions, section B, 79:68-75.

BAYLISS, P. (1975). Nomenclature of the trioctahedral chlorites. Canadian Mineralogist, 13:178-180.

BODNAR, R.J. (1993). Revised equation and table for determining the freezing point depression of $\mathrm{H}_{2} \mathrm{O}-\mathrm{NaCl}$ solutions. Geochimica et Cosmochimica Acta, 57:683-684.

BODNAR, R.J. (2003). Introduction to fluid inclusions. In: Samson, I., Anderson, A. and Marshall, D., eds., Fluid inclusions: Analysis and interpretation. Mineralogical Association of Canada Short Course Series 32, p 1-8.

BODNAR, R.J., REYNOLDS, T.J. and KUEHN, C.A. (1985). Fluid-inclusion systematics in epithermal systems. Reviews in Economic Geology, 2:73-97.

BUSSINK, R.W. (1984). Geochemistry of the Panasqueira tungsten-tin deposit. Geologica Ultraiectina, 33, 170 p. 
CARVALHO, D. (1977). Lineament patterns and hypogene mineralization in Portugal. Estudos, Notas e Trabalhos do Serviço de Fomento Mineiro, 23(3-4):91103.

CERNÁ, I., CERNÝ, P. and FERGUSON, R.B. (1972). The Tanco pegmatite at Bernie Lake, Manitoba. III. Amblygonite-montebrasite. Canadian Mineralogist, 11:643-659.

CERNÝ, P. (1991a). Rare-element granitic pegmatites - Part II: Regional and global environments and petrogenesis. Geoscience Canada, 18(2):68-81.

CERNÝ, P. (1991b). Rare-element granitic pegmatites - Part I: Anatomy and internal evolution of pegmatite deposits. Geoscience Canada, 18(2):49-67.

CERNÝ, P. and ERCIT, T.S. (2005). The classification of granitic pegmatites revisited. Canadian Mineralogist, 43:20052026.

CHAROY, B. and NORONHA, F. (1996). Multistage growth of a rare-element, volatile-rich microgranite at Argemela (Portugal). Journal of Petrology, 37:7394.

CONDE, L. and SANTARÉM, R. (1976). Exemplo de aplicação geológica de imagens de teledetecção de Portugal. Seminário sobre a Detecção Remota e sua aplicação ao estudo dos recursos naturais $e$ às actividades do homem. Lisboa, Dez. 1976, Documento 18, 7 p. [1 Mapa anexo].

COX, D.P. and SINGER, D.A., eds. (1986). Mineral deposit models. U. S. Geological Survey Bulletin, 1693, 379 p.

CRAIG, J.R. and SCOTT, S.D. (1974). Sulfide phase equilibria. Mineralogical Society of America Short Course Notes, 1, p. CS1-CS10.
CUNEY, M., MARIGNAC, C. and WEISBROD, A. (1992). The Beauvoir topazlepidolite albite granite (Massif Central, France): The disseminated magmatic SnLi-Ta-Nb-Be mineralization. Economic Geology, 87:1766-1794.

DE CARVALHO, C.N. and HAMILTON, T.G. (2017). Notas sobre a ocorrência excepcional de turquesas (fosfato hidratado de cobre e alumínio) no Cabeço da Argemela (Fundão/Covilhã). AÇAFA (Associação de Estudos do Alto Tejo) On Line nr. 12. www.altotejo.org

DEER, W.A., HOWIE, R.A. and ZUSSMAN, J. (1992). An introduction to the rock-forming minerals, $2^{\text {nd }}$ ed., Essex (UK), Longman, 696 p.

DIAS, G., SIMÕES, P.P. and MENDES, A.C. (2006). Instalação de rochas graníticas variscas na ZCI: geocronologia e sequências tipológicas. VII Congresso Nacional de Geologia, Estremoz (Évora), Univ. Évora, Livro de Resumos , vol. III, p. 1227-1229; English abstract.

DIAS, R., MOREIRA, N., RIBEIRO, A. and BASILE, C. (2017). Late Variscan deformation in the Iberian Peninsula; a late feature in the Laurentia-Gondwana dextral collision. International Journal of Earth Sciences, 106(2): 549-597.

DIAS, R., RIBEIRO, A., ROMÃO, J., COKE, C. and MOREIRA, N. (2016). A review of the arcuate structures in the Iberian Variscides: constraints and genetic models. Tectonophysics, 681: 170194.

DUBESSY, J., RAMBOZ, C., NGUYENTRUNG, C., CATHELINEAU, M., CHAROY, B., CUNEY, M., LEROY, J., POTY, B. and WEISBROD, A. (1987). Physical and chemical controls $\left(\mathrm{fO}_{2}, \mathrm{~T}\right.$, $\mathrm{pH}$ ) of the opposite behaviour of $U$ and 
Sn-W as exemplified by hydrothermal deposits in France and Great-Britain, and solubility data. Bulletin de Minéralogie, 110: 261-281.

DUDYKINA, A.S. (1959). Paragenetic associations of trace elements in cassiterites of various types of tin deposits. Moscow, Akademiya Nauk USSR, Trudy Instituta Geologii Rudnykh Mestorozhdeniyi, Petrografii, Mineralogii I Geokhimii, 28: 111-121. Russian; English abstract in Mineralogical Abstracts, 1961, v. 15, p. 105.

EADINGTON, P.J. (1983). Calculated solubilities of cassiterite in high temperature hydrothermal brines, and some applications to mineralization in granitic rocks and skarns. In: Somiya, S., ed., Proceedings of 1st International Symposium on Hydrothermal Reactions, March 1982, Tokyo, Japan, Association for Science Documents, Tokyo Institute of Technology, p. 335-345.

EADINGTON, P.J. and GIBLIN, A. (1979). Alteration minerals and the precipitation of tin in granitic rocks. CSIRO, Institute of Earth Resources, Division of Mineralogy, Sydney, Australia, Technical Communication, 68:1-31.

ECKSTRAND, O.R. (1984). Canadian mineral deposit types: A geological synopsis. Geological Survey of Canada. Economic Geology Report, 36:53-54.

EUGSTER, H.P. and WILSON, G.A. (1985). Transport and deposition of oreforming elements in hydrothermal systems associated with granites. In: Halls, C. ed., Proceedings of the Institution of Mining and Metallurgy "High heat production (HHP) granites, hydrothermal circulation and ore genesis" Conference, St. Austell, Sept. 1985, Cornwall (UK).
Institution of Mining and Metallurgy, London (UK), p. 87-95.

FERRAZ, P. (2007). $3^{\circ}$ Relatório de actividades (para a DGEG) do contrato de prospecção e pesquisa de $\mathrm{Sn}-W-\mathrm{Li}$ $\mathrm{Cu}-\mathrm{Pb}$-Zn-Au-Ag-pirites para a área da Argemela da Beralt Tin and Wolfram Portugal (BTWP). Covilhã (Portugal), BTWP, Ag. 2007, 22 p. [3 Anexos].

FERRAZ, P. (2008a). $4^{\circ}$ Relatório de actividades (para a DGEG) do contrato de prospecção e pesquisa de Sn-W-Li$\mathrm{Cu}-\mathrm{Pb}$-Zn-Au-Ag-pirites para a área da Argemela da Beralt Tin and Wolfram Portugal (BTWP). Covilhã (Portugal), BTWP, Fev. 2008, 16 p. [3 Anexos].

FERRAZ, P. (2008b). $5^{\circ}$ Relatório de actividades (para a DGEG) do contrato de prospecção e pesquisa de Sn-W-Li$\mathrm{Cu}-\mathrm{Pb}$-Zn-Au-Ag-pirites para a área da Argemela da Beralt Tin and Wolfram Portugal (BTWP). Covilhã (Portugal), BTWP, Ag. 2008, 17 p. [1 Anexo].

FERRAZ, P., RODRIGUES, B.C., OLIVEIRA, A. and RAMOS, J.F. (2010). Resultados da campanha de prospecção do jazigo de Sn-Li de Argemela. Livro de Resumos (Abstracts Book) do VII Congresso Nacional de Geologia, Univ. Minho, Braga, Portugal, p. XIII-3; e ainda e-Terra (Geosciences On-line Journal), 20(5):1-4; English abstract.

GASPAR, L.M.G.G. (1991). Alguns aspectos mineralógicos e texturais de filoes fosfatados (Argemela, Fundão). Lisboa, Faculdade Ciências, Univ. Lisboa, monografia interna, $29 \mathrm{p}$.

GEOLOGICAL MAP OF PORTUGAL (CARTA GEOLÓGICA DE PORTUGAL), escala 1:1 000000 (2010). Alfragide (Portugal), Laboratório Nacional de Energia e Geologia (LNEG). 
GOLDSTEIN, R.H. and REYNOLDS, T.J. (1994). Systematics of fluid inclusions in diagenetic minerals. Tulsa (Oklahoma): Society for Sedimentary Geology (SEPM) Short Course No. 31, 314 p.

GROAT, L.A., CHAKOUMAKOS, B.C., BROUWER, D.H., HOFFMAN, C.M., FYFE, C.A., MORELL, H., and SCHULTZ, A.J. (2003). The amblygonite $\left(\mathrm{LiAlPO}_{4} \mathrm{~F}\right)$-montebrasite (LiAl$\mathrm{PO}_{4} \mathrm{OH}$ ) solid solution: A combined powder and single-crystal neutron diffraction and solid-state ${ }^{6} \mathrm{Li}$ MAS, CP MAS, and REDOR NMR study. American Mineralogist, 88:195-210.

HAAPALA, I. and KINNUNEN, K. (1979). Fluid inclusions in cassiterite and beryl in greisen veins in the Eurajoki Stock, Southwestern Finland. Economic Geology, 74:1231-1238.

HALL, M.R. and RIBBE, P.H. (1971). An electrode microprobe study of luminescence centers in cassiterite. American Mineralogist, 56: 31-45.

HALTER, W.E., WILLIAMS-JONES, A.E. and KONTAK, D.J. (1996). The role of greisenization in cassiterite precipitation at the East Kemptville tin deposit, Nova Scotia. Economic Geology, 91:368-385.

HALTER, W.E., WILLIAMS-JONES, A.E. and KONTAK, D.J. (1998). Origin and evolution of the greisenizing fluid at the East Kemptville tin deposit, Nova Scotia, Canada. Economic Geology, 93:1026-1051.

HEINRICH, C.A. (1990). The chemistry of tin(-tungsten) ore deposition. Economic Geology, 85:457-481.

HEINRICH, C.A. and EADINGTON (1986). Thermodynamic predictions of the hydrothermal chemistry of arsenic, and their significance for the paragenetic sequence of some cassiterite-arsenopyrite, base metal sulfide deposits. Economic Geology, 81:511-529.

HOSKING, K.F.G. (1959). A geochemical reconnaissance survey at Minas da Argemela, Portugal: Camborne School of Mines Magazine, 59:5-10.

HU SHOUXI, SUN MINGZI, YAN ZHENGFU, XU JINFANG, CAO XIAOYUN and YE YING (1982). An important metallogenetic model for W, $\mathrm{Sn}$ and rare granitophile element ore deposits related to metasomatically altered granites. In: Xu Keqin and Tu Guangchi, eds., Proceedings of International Symposium on "Geology of granites and their metallogenetic relations", Nanjing, 1982. Beijing (China), Science Press, p. 519-537.

INVERNO, C. (1980). Estudo geológicoestrutural e sondagens nas Minas da Argemela. Lisboa, Serviços Geológicos de Portugal, relatório interno, 17 p. [15 Anexos].

INVERNO, C. and RIBEIRO M.L. (1980). Fracturação e cortejo filoniano nas Minas da Argemela. Comunicações Serviços Geológicos de Portugal, 66:185-193; English abstract.

INVERNO, C.M.C. (1998). Comments on the new findings on the geology, geochemistry and mineralization of Argemela. Comunicações Instituto Geológico e Mineiro, 85:73-79.

INVERNO, C.M.C., FERRAZ, P.J.V. and MOREIRA, M.E. (2009). Argemela, a high-tonnage Sn-Li deposit in Central Portugal. Abstracts with Programs of the Geological Society of America Annual Meeting, Portland (Oregon), Oct. 2009. 41(7), p. 680.

INVERNO, C.M.C. and HUTCHINSON, R.W. (2004). The endogranitic tin zone, 
Mount Pleasant, New Brunswick, Canada and its metallogenesis. Applied Earth Science, 113:261-288.

INVERNO, C.M.C. and HUTCHINSON, R.W. (2006). Petrochemical discrimination of evolved granitic intrusions associated with Mount Pleasant deposits, New Brunswick, Canada. Applied Earth Science, 115:23-39.

INVERNO, C.M.C., SOLOMON, M., BARTON, M.D. and FODEN, J. (2008). The $\mathrm{Cu}$ stockwork and massive sulfide of the Feitais volcanic-hosted massive sulfide deposit, Aljustrel, Iberian Pyrite Belt, Portugal: A mineralogical, fluid inclusion, and isotopic investigation. Economic Geology, 103:241-267.

JACKSON, K.J. and HELGESON, H.C. (1985a). Chemical and thermodynamic constraints on the hydrothermal transport and deposition of tin: I. Calculation of the solubility of cassiterite at high pressures and temperatures. Geochimica et Cosmochimica Acta, 49:1-22.

JACKSON, K.J. and HELGESON, H.C. (1985b). Chemical and thermodynamic constraints on the hydrothermal transport and deposition of tin: II. Interpretation of phase relations in the Southeast Asian Tin Belt. Economic Geology, 80:1365-1378.

JONES, W.R. (1972). General geology and the mineralization at Argimela. Appendix in: Streets CG, Minas da Argemela, Portugal. Covilhã (Portugal), Beralt Tin and Wolfram, relatório interno, $3 \mathrm{p}$.

KAMILLI, R.J. and CRISS, R.E. (1996). Genesis of the Silsilah tin deposit, Kingdom of Saudi Arabia. Economic Geology, 91:1414-1434.

KELLY, W.C. (1977). The relative timing of metamorphism, granite emplacement and hydrothermal ore deposition in Panasqueira district (Beira Baixa, Portugal). Comunicações Serviços Geológicos de Portugal, 61:239-244.

KELLY, W.C. and RYE, R.O. (1979). Geologic, fluid inclusion, and stable isotope studies of the tin-tungsten deposits of Panasqueira, Portugal. Economic Geology, 74:1721-1819.

KISSIN, S.A. (1989). A reinvestigation of the stannite $\left(\mathrm{Cu}_{2} \mathrm{FeSnS}_{4}\right)$ - kesterite $\left(\mathrm{Cu}_{2} \mathrm{ZnSnS}_{4}\right)$ pseudobinary system. Canadian Mineralogist, 27:689-697.

KOIDE, H. and BHATTACHARJI, S. (1975). Formation of fractures around magmatic intrusions and their role in ore localization. Economic Geology, 70:781799.

KRANIDIOTIS, P. and MACLEAN, W.H. (1987) Systematics of chlorite alteration at the Phelps Dodge massive sulfide deposit, Matagami, Quebec. Economic Geology, 82:1898-1911.

LATTANZI, P., CORAZZA, M., CORSINI, F. and TANELLI, G. (1989). Sulfide mineralogy in the polymetallic cassiterite deposits of Dachang, P. R. China. Mineralium Deposita, 24:141-147.

LEHMANN, B. (1990). Metallogeny of tin. In: Bhattacharji, S., Friedman, G.M., Neugebauer, H.J. and Seilacher, A., eds. Berlin, Springer-Verlag, Lecture Notes in Earth Sciences, No. 32, 211 p.

LINNEN, R.L. (1998). Depth of emplacement, fluid provenance and metallogeny: a comparison of western Thailand with other tin belts. Mineralium Deposita, 33(5):461-476.

LONDON, D. and MANNING, D.A.C. (1995). Chemical variation and significance of tourmaline from Southwest England. Economic Geology, 90:495-519. 
LONDON, D., WOLF, M.B., MORGAN VI, G.B. and GARRIDO, M.G. (1999). Experimental silicate-phosphate equilibria in peraluminous granitic magmas, with a case study of the Albuquerque Batholith at Tres Arroyos, Badajoz, Spain. Journal of Petrology, 40:215-240.

LU, H.-Z., LIU YIMAO, WANG CHANGLIE, XU YOUZHI and $\mathrm{Li}$ HUAQIN (2003). Mineralization and fluid inclusion study of the Shizhuyuan W-Sn-Bi-Mo-F skarn deposit, Hunan province, China. Economic Geology, 98:955-974.

LUSK, J. and FORD, C.E. (1978). Experimental extension of the sphalerite geobarometer to 10 kbar. American Mineralogist. 63:516-519.

MARTINS, F.J.C.T. (2017). Indicadores geoquímicos na prospecção de W e Sn: estudo aplicado à mina de Vale Pião, Góis. Tese de Mestrado em Geologia Económica, Faculdade de Ciências, Univ. Lisboa, 79 p. [1 CD anexo]; English abstract.

MATERIKOV, M.P. (1977). Deposits of tin. In: Smirnov, V.I., ed., Ore deposits of the USSR. London (UK), Pitman Publishing, v. 3, p. 229-294.

MATEUS, A. and NORONHA, F. (2010). Sistemas mineralizantes epigenéticos na Zona Centro-Ibérica; exptressão da estruturação orogénica meso- a tardiVarisca. In: Neiva, J.M.C., Ribeiro, A., Victor, M., Noronha, F. and Ramalho M., eds., Ciências Geológicas - Ensino e Investigação e sua História. Associação Portuguesa de Geólogos - Sociedade Geológica de Portugal, v. II (Geologia Aplicada), cap. I (Geologia e Recursos Geológicos), p. 47-61; English abstract.

MICHAUD, J., MARCOUX, E., PICHAVANT, M., GUMIAUX, C. and GLOAGEN, E. (2017). From rare metal granite to $\mathrm{Sn}-\mathrm{W}-\mathrm{Li}-\mathrm{Nb}-\mathrm{Ta}$ mineralizations: results on Argemela (Central Portugal). Goldschmidt 2017 Abstracts.

MIGDISOV, A.A. and WILLIAMSJONES, A.E. (2005). An experimental study of cassiterite solubility in $\mathrm{HCl}$ bearing water vapour at temperatures up to $350^{\circ} \mathrm{C}$. Implications for tin ore formation. Chemical Geology, 217:29-40.

MÜLLER, B. and SEWARD, T.M. (2001). Spectrophotometric determination of the stability of tin(II) chloride complexes in aqueous solution up to $300^{\circ} \mathrm{C}$. Geochimica et Cosmochimica Acta, 65( 22):4187-4199.

MÜLLER, B., FRISCHKNECHT, R., SEWARD, T.M., HEINRICH, C.A. and GALLEGOS, W.C. (2001). A fluid inclusion reconnaissance study of the Huanuni tin deposit (Bolivia), using LA-ICP-MS micro-analysis. Mineralium Deposita, 36:680-688.

NAKAMURA, Y. and SHIMA, H. (1982). $\mathrm{Fe}$ and $\mathrm{Zn}$ partitioning between stannite and sphalerite. Abstracts of the Joint Meeting of the Society of Mining Geologists of Japan, the Mineralogical Society of Japan and the Japanese Association of Mineralogists, Petrologists and Economic Geologists, A-8.

NEIVA, A.M.R. (1996). Geochemistry of cassiterite and its inclusions and exsolution products from tin and tungsten deposits in Portugal. Canadian Mineralogist, 34:745-768.

NEKRASOV, I.J., SOROKIN, V.I. AND OSADCHII, E.G. (1979). Fe and $\mathrm{Zn}$ partitioning between coexisting stannite and sphalerite and its application in geothermometry. In: Ahrens, L.H., ed., Origin and distribution of the elements. Pergamon Press, p. 739-742. 
NIKULIN, N.N. (1969). The distribution of indium, niobium, and scandium in the cassiterites of the Khingan deposit. Leningrad Univ., Vesta, No. 6, Geol. Geogr., No. 1, p. 81-87, and Mineralogical Abstracts, 20, p. 108.

NORONHA, F., DÓRIA, A., DUBESSY, J. and CHAROY, B. (1992). Characterization and timing of the different types of fluids present in the barren and ore-veins of the W-Sn deposit of Panasqueira, Central Portugal. Mineralium Deposita. 27:72-79.

NORONHA, F., RIBEIRO, M.A., ALMEIDA, A., DÓRIA, A., GUEDES, A., LIMA, A., MARTINS, H.C., SANT'OVAIA, H., NOGUEIRA, P., MARTINS, T. et al. (2013). Jazigos filonianos hidrotermais e aplitopegmatíticos espacialmente associados a granitos (norte de Portugal). In: Dias, R., Araújo, A., Terrinha, P. and Kullberg, J.C., eds., Geologia de Portugal. Lisboa, Escolar Editora, v. 1, 403-438.

NORRIS, D. (1962). Report on history of operations in Argemela. Covilhã (Portugal), Beralt Tin and Wolfram, relatório interno.

OOSTEROM, M.G. (1988). The geochemistry of granitoid-related tin and tungsten deposits in orogenic belts. In: Hutchison, C.S., ed., Geology of tin deposits in Asia and the Pacific. Berlin, Springer-Verlag, p. 187-199.

OOSTEROM, M.G., BUSSINK, R.W. and VRIEND, S.P. (1984). Lithogeochemical studies of aureoles around the $\mathrm{Pa}$ nasqueira tin-tungsten deposit, Portugal. Mineralium Deposita, 19:283-288.

PABALAN, R.T. (1986). Solubility of cassiterite $\left(\mathrm{SnO}_{2}\right)$ in $\mathrm{NaCl}$ solutions from $200^{\circ} \mathrm{C}-350^{\circ} \mathrm{C}$, with geologic applications.
PhD dissertation, State College (PA), Pennsylvania State University, $141 \mathrm{p}$.

PALACHE, C., BERMAN, H. and FRONDEL, C. (1951). The system of mineralogy. New York (NY), John Wiley and Sons; v. 2, 1124 p.

PARRA, A.A.H.N. (1988). Jazida estanovolframítica de Vale Pião. Aspectos geológicos e cálculo preliminar de reservas. Lisboa, Serviço de Fomento Mineiro, relatório interno, 64 p. [2 Anexos].

PATTERSON, D.J., OHMOTO H.H. and SOLOMON, M. (1981). Geologic setting and genesis of cassiterite-sulfide mineralization at Renison Bell, Western Tasmania. Economic Geology, 76:393-438.

PEACOR, D.R., DUNN, P.J., ROBERTS, W.L., CAMPBELL, T.J. and SIMMONS, W.B. (1984). Sinkankasite, a new phosphate from the Barker pegmatite, South Dakota. American Mineralogist, 69:380-382.

POHL, W. and GÜNTHER, M.A. (1991). The origin of Kibaran (late Mid-Proterozoic) tin, tungsten and gold quartz vein deposits in Central Africa: a fluid inclusion study. Mineralium Deposita, 26:51-59.

POLYA, D.A. (1989). Chemistry of the main-stage ore-forming fluids of the Panasqueira $\mathrm{W}-\mathrm{Cu}(\mathrm{Ag})-\mathrm{Sn}$ deposit, Portugal: Implications for models of ore genesis. Economic Geology, 84:1134-1152.

POTTER II, R.W. (1977). Pressure corrections for fluid-inclusion homogenization temperatures based on the volumetric properties of the system $\mathrm{NaCl}-\mathrm{H}_{2}$ O. U.S. Geological Survey Journal of Research, 5:603-607.

POTTER II, R.W. and BROWN, D.L. (1977). Preliminary steam tables for $\mathrm{NaCl}$ solutions - the volumetric prop- 
erties of aqueous sodium chloride solutions from $0^{\circ} \mathrm{C}$ to $500^{\circ} \mathrm{C}$ at pressures up to 2000 bars on a regression of available data in the literature. U.S. Geological Survey Bulletin, 1421-C, 36 p.

REN, S.K., WALSHE, J.L., PATERSON, R.G., BOTH, R.G. and ANDREW, A. (1995). Magmatic and hydrothermal history of porphyry-style deposits of the Ardlethan tin field, New South Wales, Australia. Economic Geology, 90:1620-1645.

RIBEIRO, A., CONDE, L. and CARVALHO, D. (1974). Relatório da visita às Minas da Argimela: Beja, Serviço de Fomento Mineiro (Portugal), relatório interno, 8 p.

RIBEIRO, A. and PEREIRA, E. (1982). Controles paleogeográficos, petrológicos e estruturais na génese dos jazigos portugueses de estanho e volfrâmio. Geonovas, 1(3):23-31; English abstract.

RODA-ROBLES, E., GIL-CRESPO, P., LIMA, A., PESQUERA, A., VIEIRA, R. and MARTINS, T. (2011). Pegmatites from the Central Iberian and Galizia-Trás-os-Montes zones (Iberian Massif) (Spain and Portugal): Characteristics and exploration significance for $\mathrm{Li}$ and other rare-elements, In: Martins, L.M.P., de Oliveira, D.P.S., Silva, R., Viegas, H.M.C. and Bôas, R.C.V., eds., Valorização de pegmatitos litiníferos. Lisboa (Portugal), DGEG/LNEG/ADI/ CYTED, p. 67-68.

RODA-ROBLES, E., PESQUERA, A., GIL-CRESPO, P., VIEIRA, R., LIMA, A., GARATE-OLAVE, I., TORRESRUIZ, J. and MARTINS, T. (2016). Geology and mineralization in the Central Iberian Zone (Spain and Portugal). Mineralogical Magazine, 80(1):103-126.
ROEDDER, E. (1984). Fluid inclusions. Reviews in Mineralogy, 12, $646 \mathrm{p}$.

ROEDDER, E. and BODNAR, R.J. (1980). Geologic pressure determinations from fluid inclusion studies. Annual Review of Earth and Planetary Sciences. 8:263-301. ROMÃO, J., METODIEV, D., DIAS, R. and RIBEIRO, A. (2013). Evolução geodinâmica dos sectores meridionais da Zona Centro-Ibérica. In: Dias, R., Araújo, A., Terrinha, P.and Kullberg, J.C., eds., Geology of Portugal. Lisboa, Escolar Editora, v. 1, p. 205-257.

SANTARÉM, R. (1983). Interpretação fotogeológica da região centro de Portugal. Estruturas circulares e fracturas com base em imagens do Satélite Landsat 2. Estudos, Notas e Trabalhos do Serviço de Fomento Mineiro, 25(3-4):227-245; English abstract.

SANT'OVAIA, H., NOGUEIRA, P., LOPES, J.C. and GOMES, C. (2015). Building up of a nested granite intrusion: magnetic fabric, gravity modelling and fluid inclusion planes studies in Santa Eulália Plutonic Complex (Ossa Morena Zone, Portugal). Mineralogical Magazine, 152(4):648-667.

SHCHERBA, G.N. (1970). Greisens. International Geology Review, 12:114-150, 239-255.

SCHERMERHORN, L.J.G. (1982). Framework and mineralization of Hercynian mineralization in the Iberian Meseta. Comunicações Serviços Geológicos de Portugal, 68(1):91-140.

SCOTT, S.D. and KISSIN, S.A. (1973). Sphalerite composition in the $\mathrm{Zn}-\mathrm{Fe}-\mathrm{S}$ system below $300^{\circ} \mathrm{C}$. Economic Geology, 68:475-479.

SHEPERD, T.J. and MILLER, M.F. (1988). Fluid inclusion volatiles as a guide to 
tungsten deposits, southwest England: Applications to other $\mathrm{Sn}-\mathrm{W}$ provinces in western Europe. In: Boissonnas, J. and Omenetto, P., eds., Mineral deposits within the European Community. Berlin (Germany), Springer-Verlag, p. 29-52.

SHEPERD, T.J., RANKIN, A.H. and ALDERTON, D.H.M. (1985). A practical guide to fluid inclusion studies. Glasgow (UK), Blackie \& Son, 239 p.

SHEPPARD, S.M.F. (1981). Stable isotope geochemistry of fluids. Physics Chemistry Earth, 13-14:165-184.

SHIGLEY, J.E. and BROWN, G.E., JR. (1985). Occurrence and alteration of phosphate minerals at the Stewart Pegmatite, Pala District, San Diego County, California. American Mineralogist, 70:398-408.

SHIMIZU, M. and SHIKAZONO, N. (1985). Iron and zinc partitioning between coexisting stannite and sphalerite: a possible indicator of temperature and sulfur fugacity. Mineralium Deposita, 20:314-320.

SINCLAIR, W.D., KOOIMAN, G.J.A., MARTIN, D.A. and KJARSGAARD, I.M. (2006). Geology, geochemistry and mineralogy of indium resources at Mount Pleasant, New Brunswick, Canada. Ore Geology Reviews, 28:123-145.

SIORMINP (2002). Sistema de Informação de Ocorrências e Recursos Mineiros Portugueses (Coords., A. Parra e A. Filipe). Alfragide, Instituto Geológico e Mineiro: 2164 deposits.

SPRINGER, G. (1972). The pseudobinary system $\mathrm{Cu}_{2} \mathrm{FeSnS}_{4}-\mathrm{Cu}_{2} \mathrm{FeSnS}_{4}$, and its mineralogical significance. Canadian Mineralogist, 27:689-697.

STEMPROK, M. (1984). Genetic types of tin deposits in the north-western part of the Bohemian Massif of Czechoslovakia. Abstracts of the Chinese Academy of Geological Sciences "International Symposium on Geology of Tin Deposits", Beijing, China, 1984, p.12-13.

STEVESON, B.G. and TAYLOR, R.G. (1973). Trace element content of some cassiterites from eastern Australia. Proceedings Royal Society Queensland, 84:43-54.

STREETS, C.G. (1972), Minas da Argimela, Portugal: Covilhã (Portugal), Beralt Tin and Wolfram, relatório interno, $20 \mathrm{p}$.

TAYLOR, R.G. (1979). Geology of tin deposits. Amsterdam: Elsevier, Developments in Economic Geology, v. 11, 543 p.

TAYLOR, R.G. and WALL, V.J. (1993). Cassiterite solubility, tin speciation and transport in a magmatic aqueous phase. Economic Geology, 88:437-469.

THADEU, D. (1951). Geology of the Panasqueira mining district. Comunicações Serviços Geológicos de Portugal, 32:5-64.

THADEU, D. (1965). Carta Mineira de Portugal, 1:500 000 - Notícia Explicativa. Lisboa, Serviços Geológicos de Portugal, $46 \mathrm{p}$.

WAGNER, T., MLYNARCZYK, M.S.J., WILLIAMS-JONES, A.E. and BOYCE, A.J. (2009). Stable isotope constraints on ore formation at the San Rafael tin-copper deposit, southeast Peru. Economic Geology, 94:223-248.

WHYTE, W.J. (1973). Minas da Argimela, Portugal: Ore reserve summary. Covilhã (Portugal), Beralt Tin and Wolfram, relatório interno, $12 \mathrm{p}$.

WILSON, G.A. and EUGSTER, H.P. (1990). Cassiterite solubility and tin speciation in supercritical chloride solutions. Geochemical Society Special Publication 2, p. 179-195. 
WRIGHT, J.H. and KWAK, T.A.P. (1989). Tin-bearing greisens of Mount Bischoff, Northwestern Tasmania, Australia. Economic Geology, 84:551-574.
ZANE, A. and WEISS, Z. (1998). A procedure for classifying chlorites based on microprobe data. Rendiconti Lincei - Academia dele Szienze Fisiche e Naturali, s. 9 , v. 9 , p. 51-56.

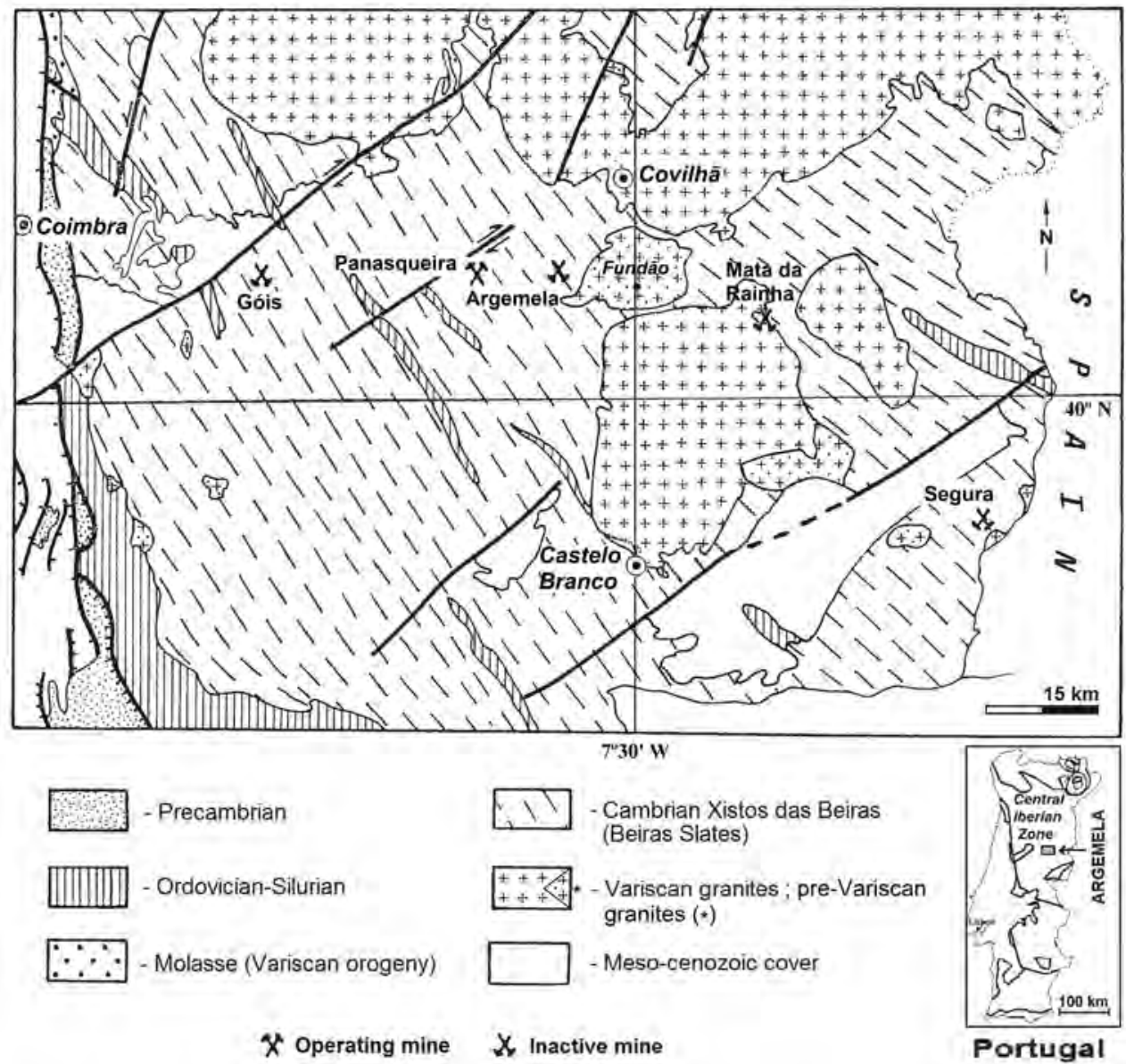

Fig. 1. Regional geology; inset with location of Argemela deposit in Portugal and within the Central Iberian Zone among the geotectonic zones (modified from INVERNO and RIBEIRO, 1980). 


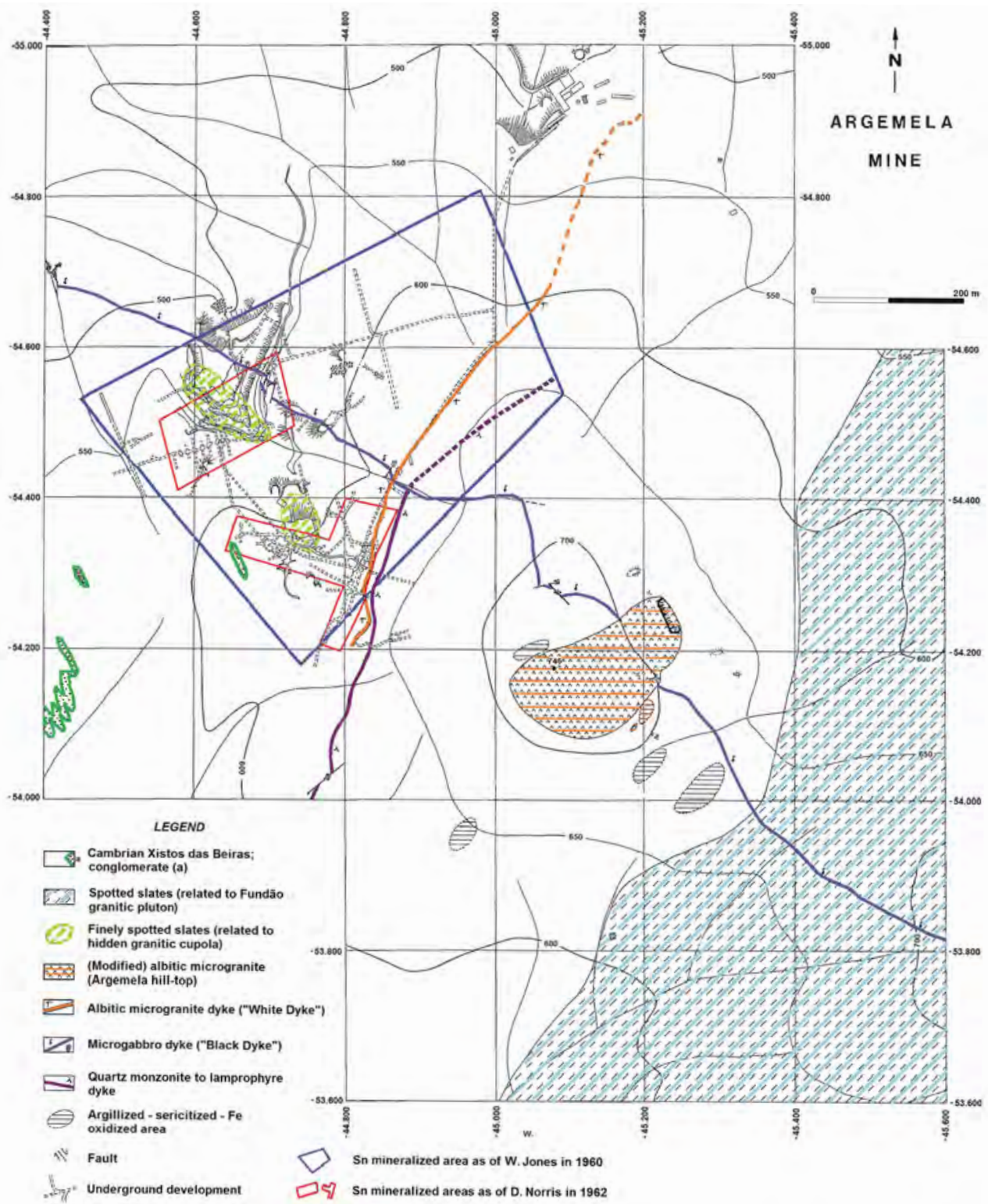

Fig. 2. Geologic surface map of Argemela deposit, reduced from a 1:2,000 scale (modified from INVERNO and RIBEIRO, 1980). 


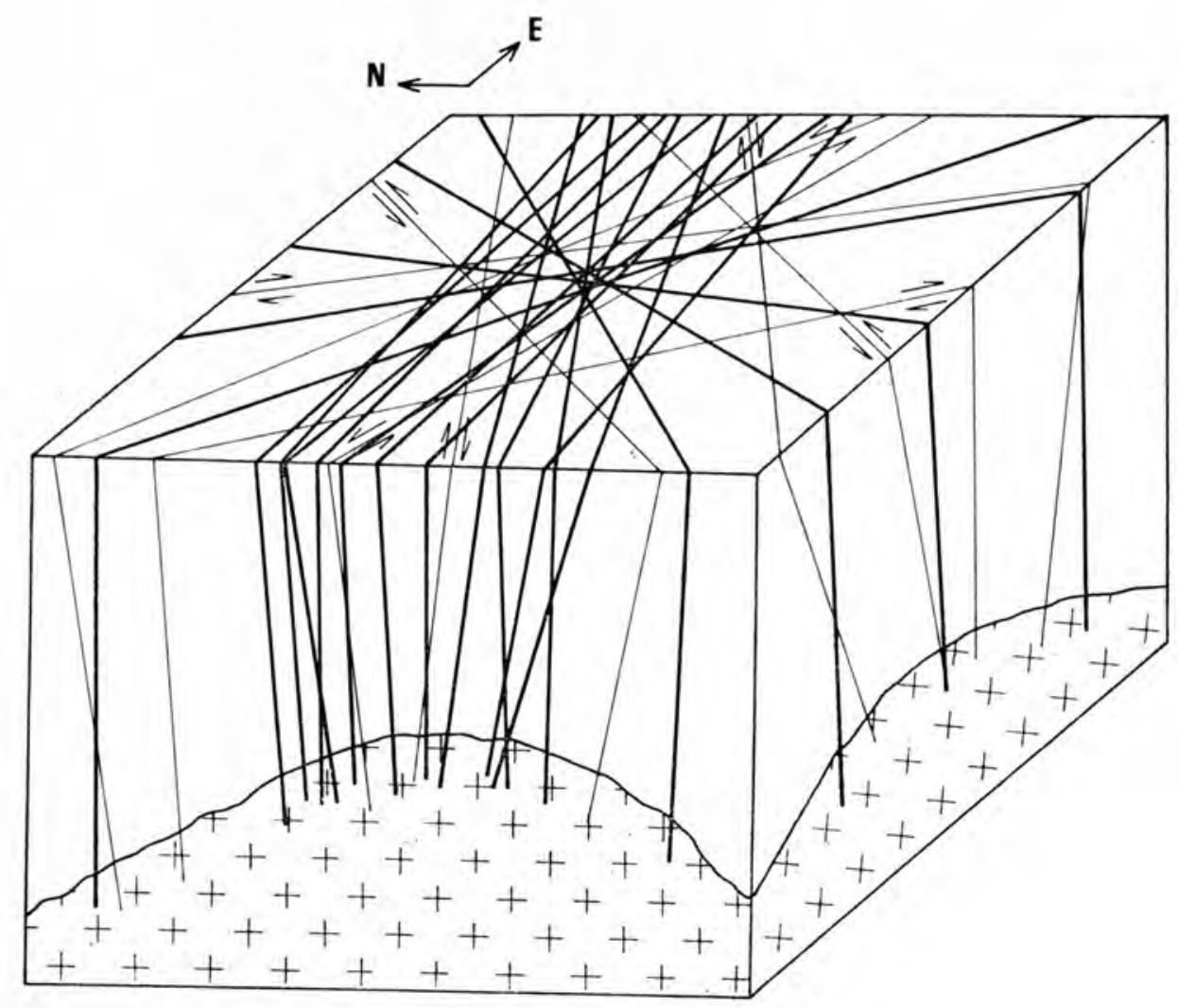

Mineralized tension fractures

\section{Mineralized shear fractures}

Fig. 3. Block-diagram with attitude of the different mineralised veins and a hidden granitic cupola (from INVERNO and RIBEIRO, 1980). 


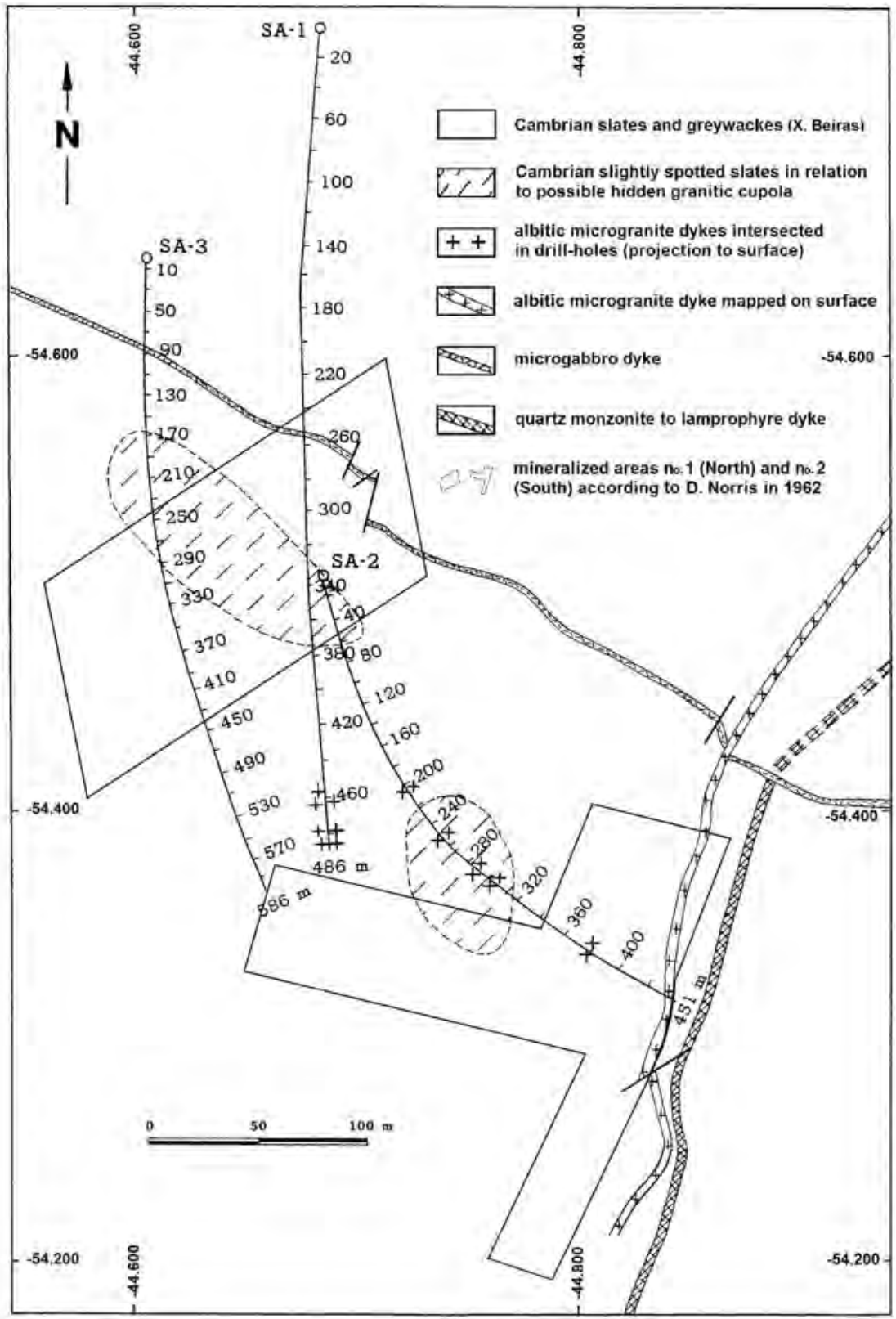

Fig. 4. Location of long, deep drill-holes in relation to slightly spotted slates and to dikes [on surface and in core, vertically projected to surface] (modified from INVERNO, 1998). 

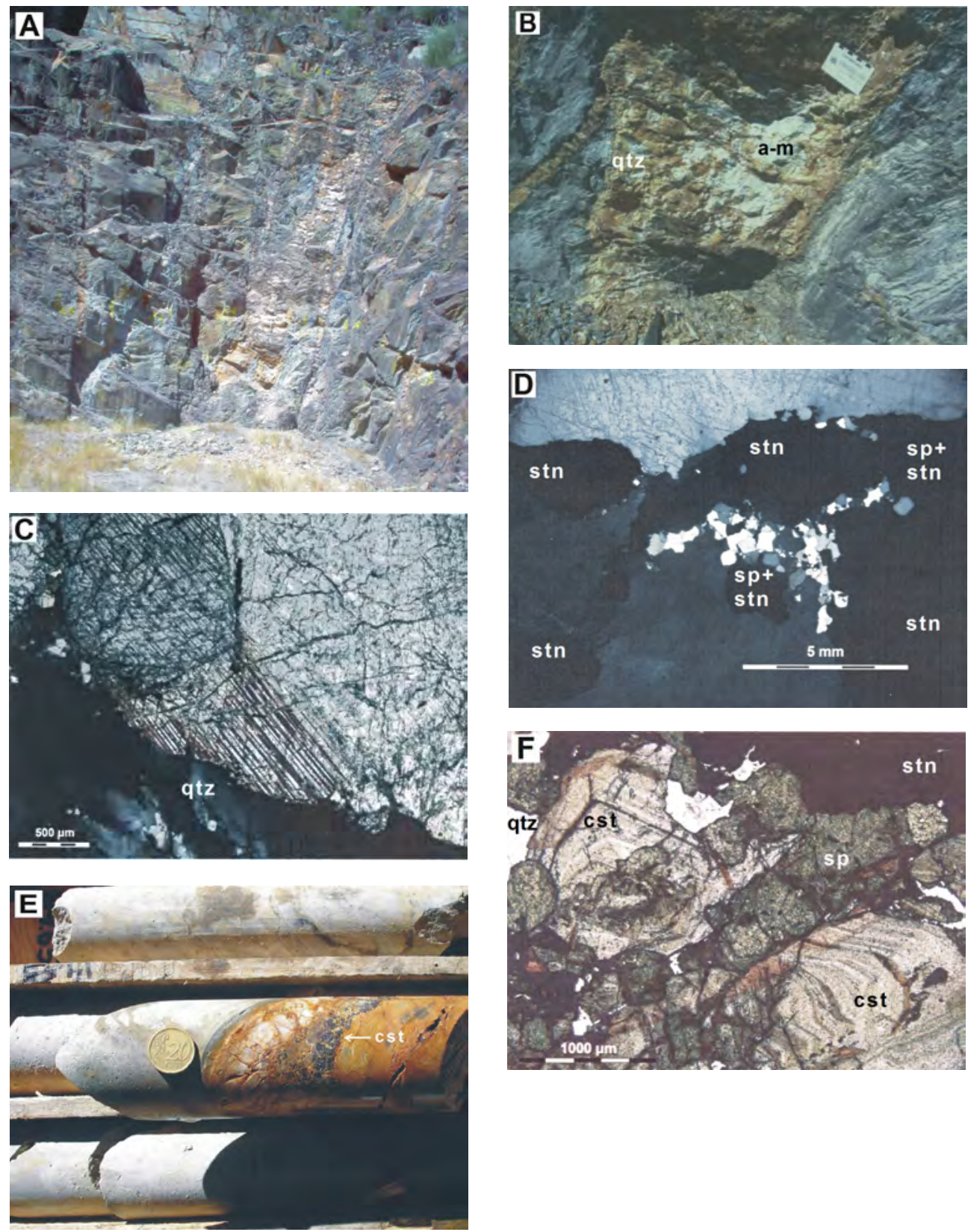

Fig. 5. Photographs of surface exposures and photomicrographs of polished thin sections of Argemela mineralised veins. (A) Stockwork mineralised veins, hosted in Cambrian slates, at open pit, from Level 1 upwards. The rock exposure is about $10 \mathrm{~m}$ high and the quartz veins in the central part of the lower bench have a 

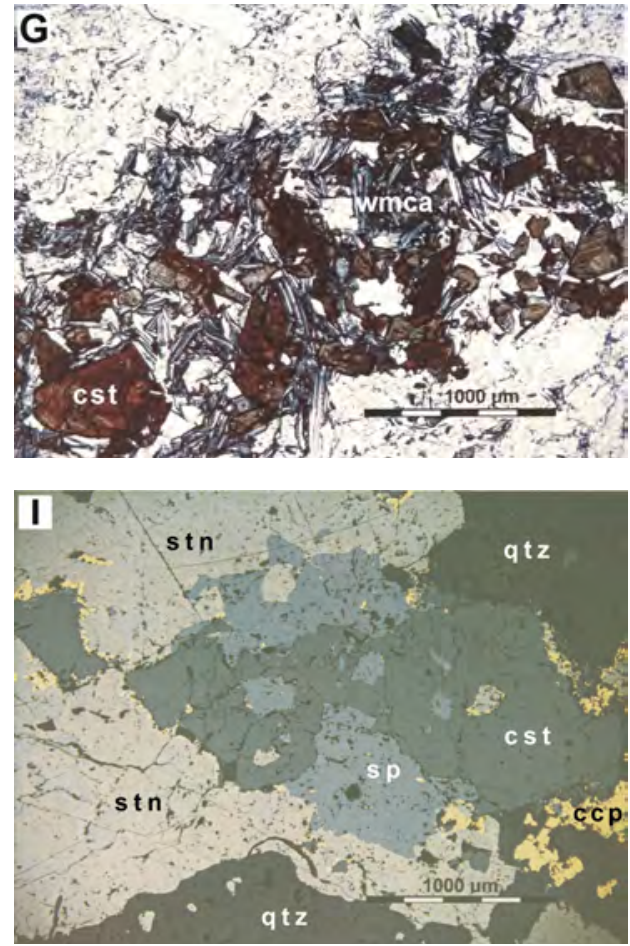

hammer for scale. (B) Detail of lower part of rock exposure in Figure 5A. Slate-hosted stockwork vein with quartz (qtz) and amblygonite-montebrasite (a$\mathrm{m})$ (plus supergene phosphates). (C) Amblygonite-montebrasite in contact with quartz I (qtz), that penetrates the former mineral as seen on lower right and upper left. Sample SA1-7; transmitted light (TL), crossed polars $(\mathrm{P}+)$. (D) Coarser quartz I, with abundant fluid inclusions and undulose extinction, and finer quartz II, with fewer fluid inclusions (both quartz I and II: light and dark grey), and adjacent to opaque minerals (in this case stannite[-group mineral] (stn) and sphalerite (sp)). Sample SA3-4; $\mathrm{TL}, \mathrm{P}+$. (E) Slate-hosted stockwork quartz vein with aggregate of cassiterite (cst) in internal vein wall. (F) Two crystals of cassiterite (cst) in quartz vein, with well-developed internal zoning, replaced by sphalerite (sp). - 101- growth twins in longer cassiterite grain. Stannite[-group mineral] (stn) and quartz I (qtz) also present. Sample SA2-7a; TL. (G) White mica (wmca) - cassiterite (cst) microveinlet in albitic microgranite dyke. Sample SA1-9; TL. (H)
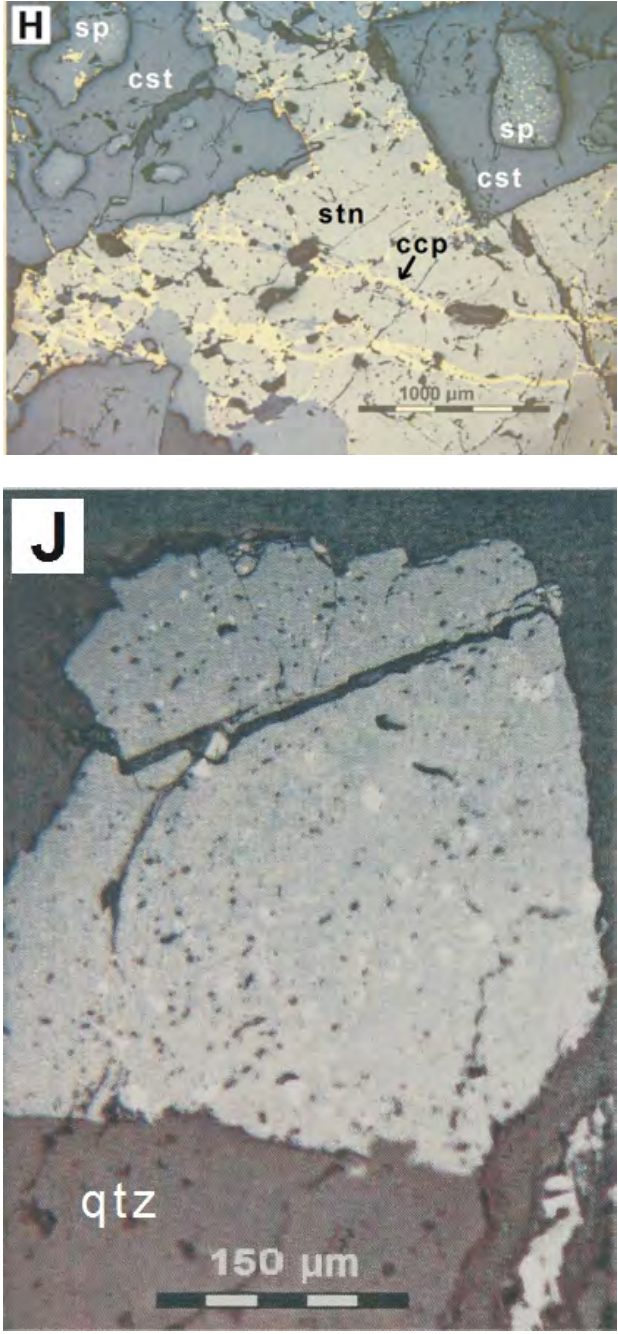

Chalcopyrite (ccp) microveinlets in stannite-group mineral] (stn). Also cassiterite (cst) grains replaced by sphalerite (sp) with chalcopyrite disease. Sample SA2-7a; reflected light (RL). (I) Cassiterite (cst) surrounded by sphalerite (sp), in turn wrapped by stannite[-group mineral] (stn). Chalcopyrite (ccp) mostly rimming cassiterite. Quartz I and II (qtz) on the bottom part and upper right corner, respectively. Sample SA1-6; RL. (J) Cassiterite grain, with abundant light-coloured columbite-tantalite inclusions (mostly up to $10 \mu \mathrm{m}$ wide), surrounded by quartz I (qtz). Sample SA2-4a; RL. 

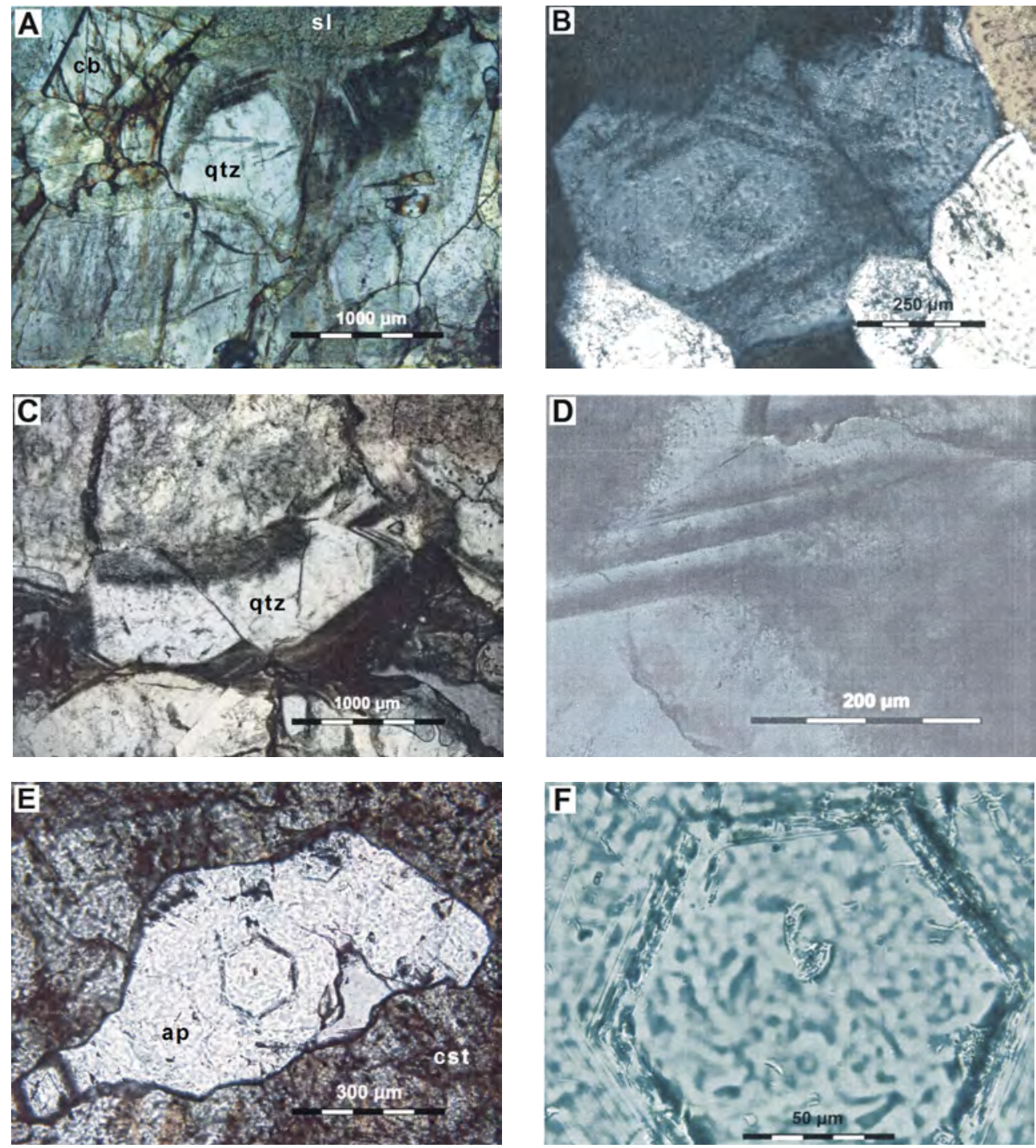

Fig. 6. Transmitted-light photomicrographs of Argemela stockwork vein crystals and their fluid inclusions. (A) A 4 mm-wide quartz I (qtz) crystal with prominent growth zones on the upper portion with primary fluid inclusions. Abundant swarms of secondary FIAs on lower left. Carbonate (cb) crystal with rhombohedral cleavage on upper left and slate (sl) host rock on top and upper right. Sample SA1-5. (B) Quartz II crystal (800 $\mu \mathrm{m}$ wide) exhibiting well-developed growth zones with primary fluid inclusions. Sample SA1-5(R). (C) Quartz I (qtz) grain (2.5 mm long) with growth zones, particularly well developed on the right tip, with primary fluid inclusions. Sample SA1-5. (D) Detail of right tip of quartz I crystal in Figure 6C, showing growth zones with very tiny primary fluid inclusions. Sample SA1-5. (E) Apatite (ap) grain with prominent growth zone with primary fluid inclusions. Surrounded by cassiterite (cst). Sample SA3-5. (F) Detail of apatite in 

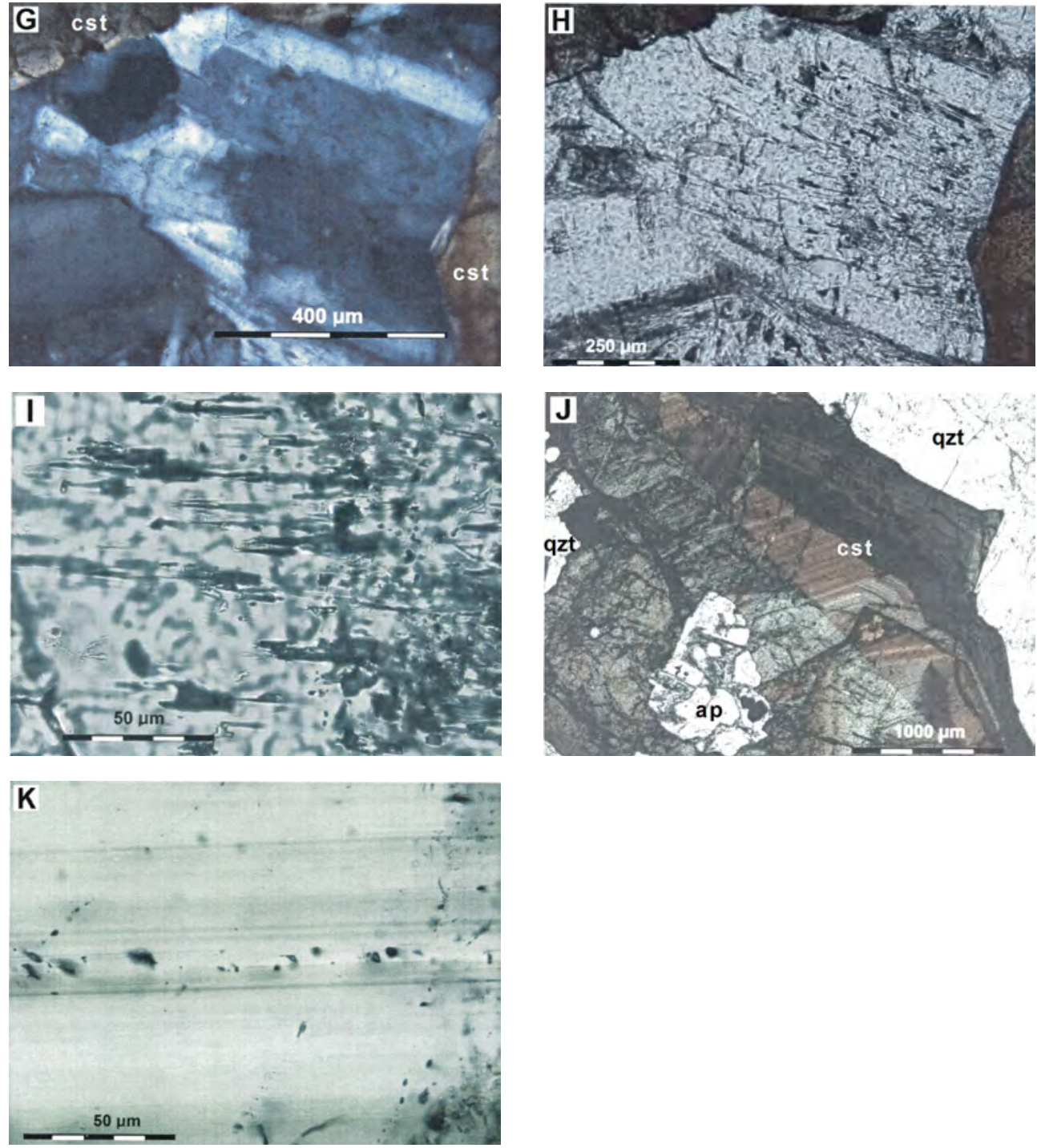

Figure $6 \mathrm{E}$, showing growth zone with mostly $\mathrm{V}+\mathrm{L}$ primary fluid inclusions and also abundant solid inclusions. Sample SA3-5. (G) Apatite crystal with well-developed growth zone on the outer portion. Cassiterite (cst) rimming apatite crystal. Sample SA3-5; P+. (H) Same apatite crystal from Figure 6G, with inner part of the growth zone with abundant primary, tubular, either 5-10 $\mu \mathrm{m}$-wide $\mathrm{V}+\mathrm{L}$ inclusions or 14-60 $\mu \mathrm{m}$-wide, all dark $\mathrm{V}$ inclusions. Sample SA3-5. (I) Detail of central part of apatite crystal in Figure 6H, exhibiting primary tubular inclusions, either $<10 \mu \mathrm{m}$-wide $\mathrm{V}+\mathrm{L}$ inclusions or darker and longer $(14-60 \mu \mathrm{m}) \mathrm{V}$ inclusions. Sample SA3-5. (J) Growth bands in cassiterite. Also showing prominent -101- growth twin. Quartz I (qtz) and apatite (ap) also present. Sample SA3-5. (K) Detail of right part of cassiterite grain in Figure 6J, exhibiting growth bands with a few 1-10 $\mu \mathrm{m}$-wide primary fluid inclusions. Also "NE-SW" planes, with FIAs containing secondary fluid inclusions, transecting the growth bands. Sample SA3-5. 

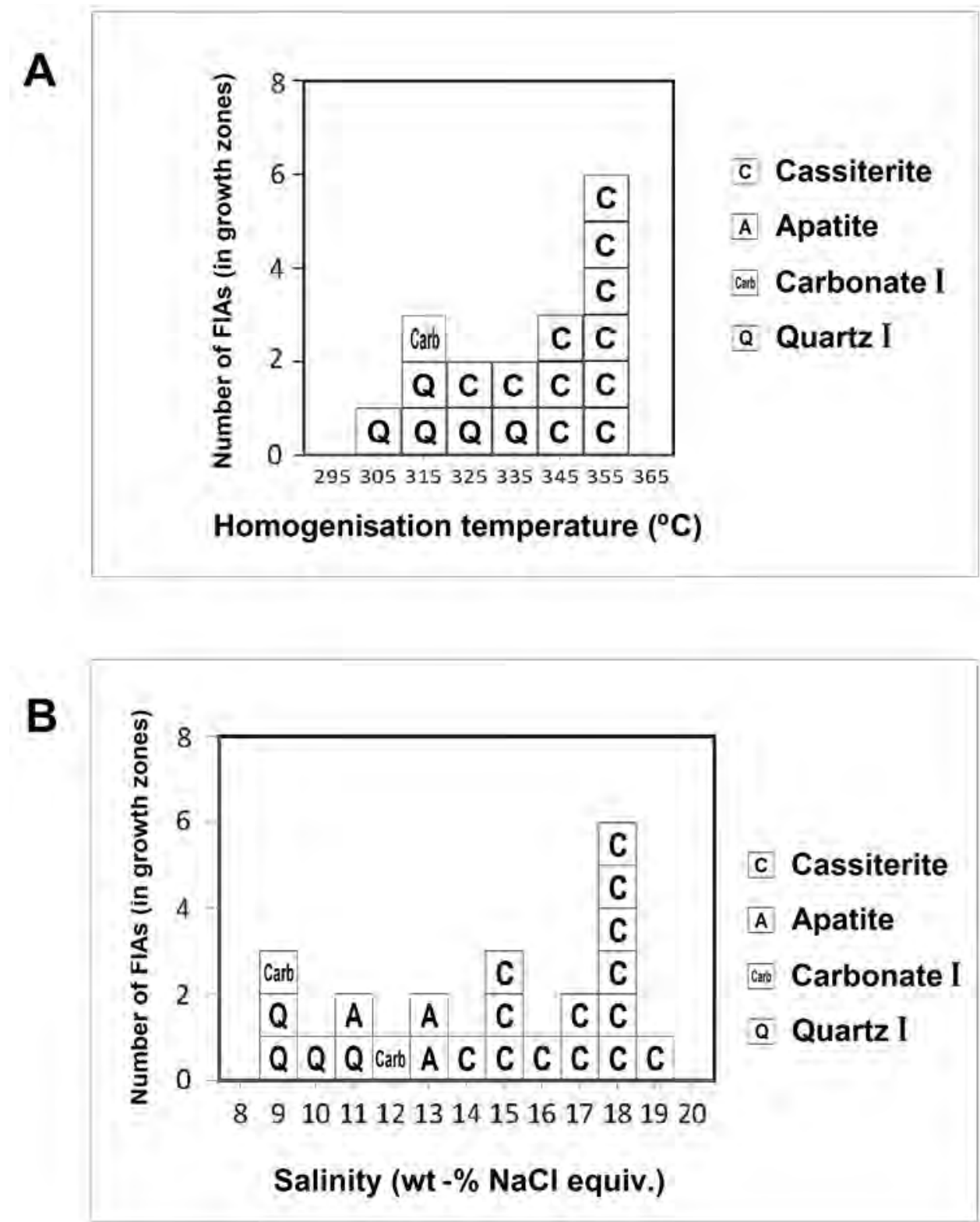

Fig. 7. Frequency histograms with number of FIAs with primary fluid inclusions (in growth zones) in quartz I, carbonate I, apatite and cassiterite grains from mineralised quartz veins in the Argemela deposit, considering each FIA average for: (A) Homogenisation temperature; (B) Salinity. 

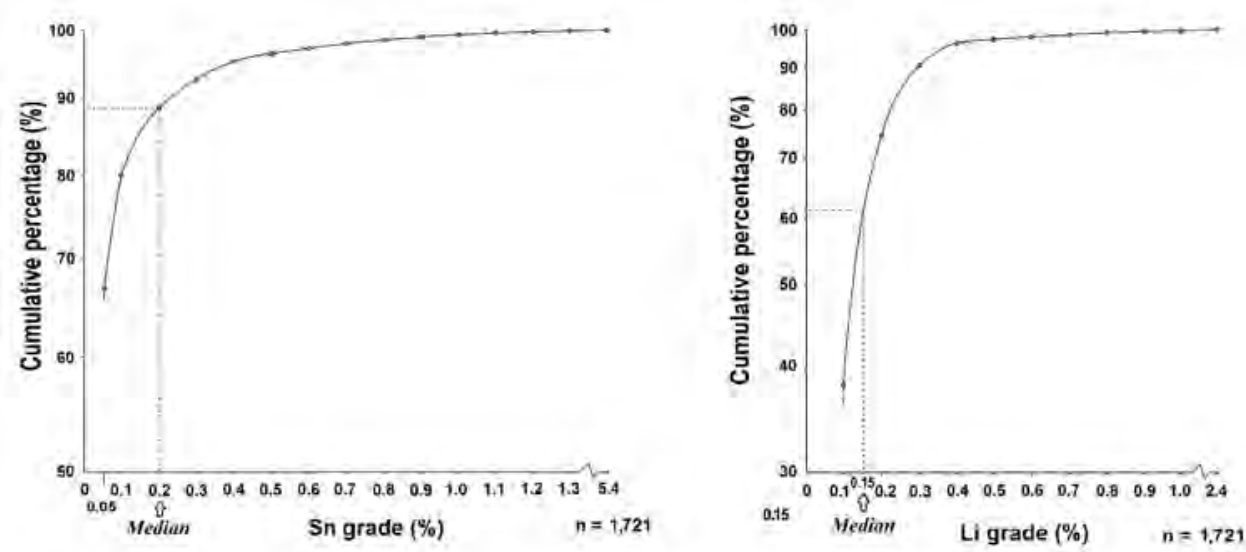

Fig. 8. Cumulative percentage plots for $\mathrm{Sn}$ and $\mathrm{Li}$ for all $(\mathrm{n}=1,759)$ the Argemela analysed samples (from surface, underground - Level 1, and core from deep and shallow drill-holes), with median values of $0.2 \% \mathrm{Sn}$ and $0.15 \% \mathrm{Li}$.

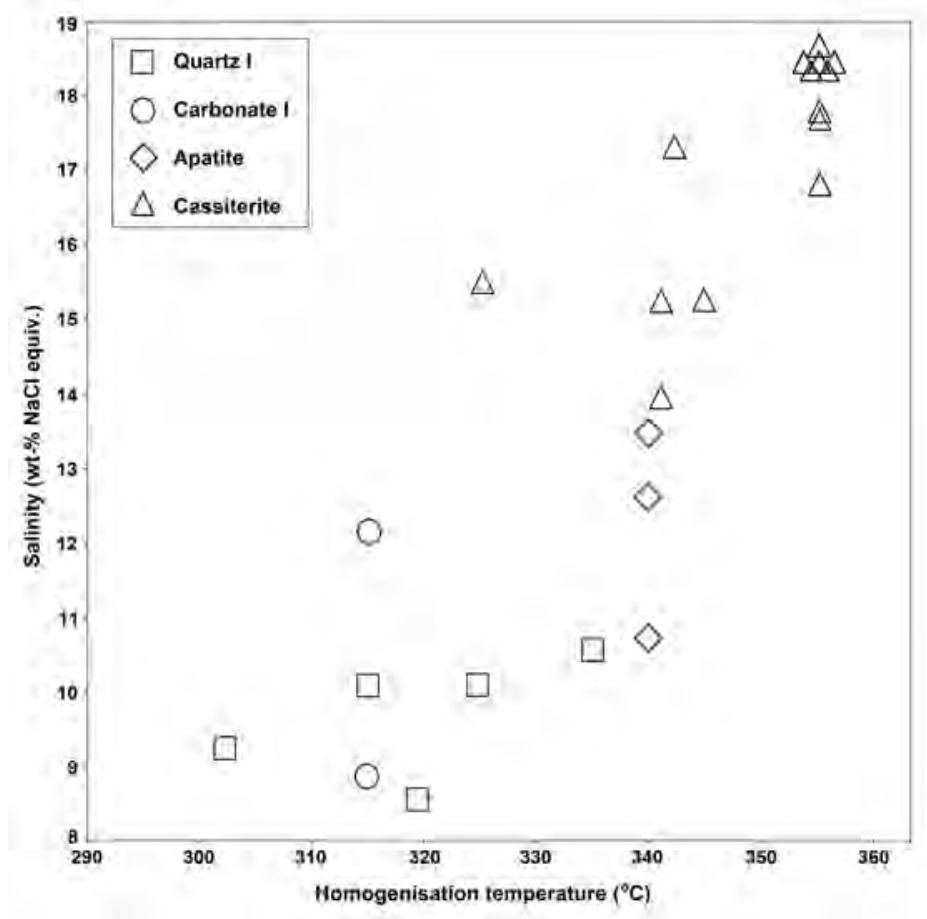

Fig. 9. Homogenisation temperature versus salinity for each set of determined primary inclusions in individual FIAS in growth zones in quartz I, carbonate I, apatite and cassiterite. 


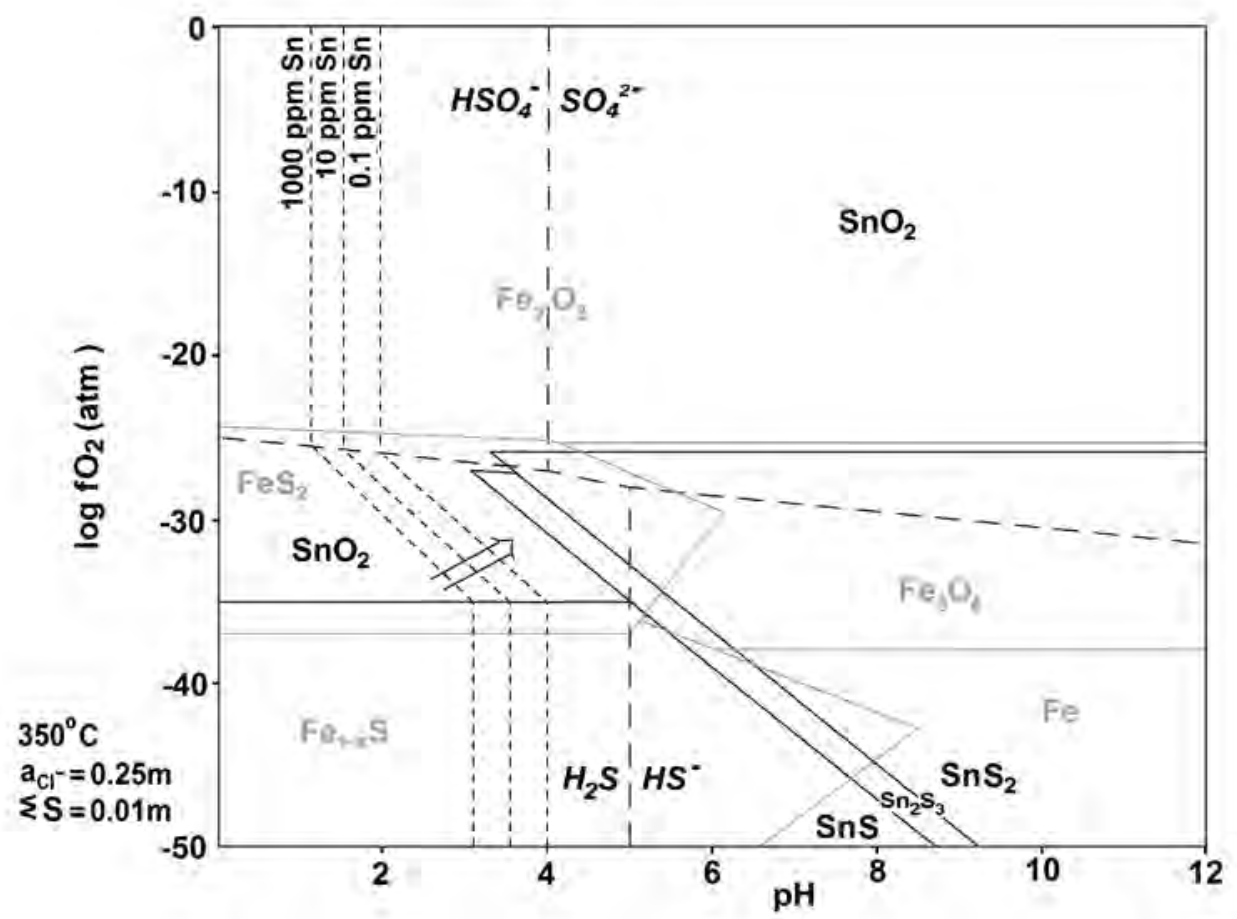

Fig. 10. Calculated $\mathrm{fO} 2-\mathrm{pH}$ diagram for the system $\mathrm{Sn}-\mathrm{S}-\mathrm{O}$, superimposed on the system $\mathrm{Fe}-\mathrm{S}-\mathrm{O}$, and including the sulphur-containing aqueous species, at $350^{\circ} \mathrm{C}, \mathrm{aCl}-=0.25 \mathrm{~m}$ and assuming an activity of $\sum \mathrm{S}$ of $0.01 \mathrm{~m}$. Both $\mathrm{Sn}$ oxide and sulphide phases and Fe oxide and sulphide phases, as well as sulphur aqueous species are plotted, together with solubility contours for the sum of activities of $\mathrm{SnCl}^{\circ}$ and $\mathrm{SnCl} 3+$ representing total Sn solubility. Cassiterite precipitation in Argemela stockwork veins according to the deposition arrow. 


\begin{tabular}{|c|c|c|}
\hline Element & Line & Standard \\
\hline $\mathrm{Zn}$ & $\mathrm{K} \alpha$ & $\mathrm{ZnS}$ \\
\hline $\mathrm{Fe}$ & $\mathrm{K} \alpha$ & $\mathrm{FeS}_{2}$ \\
\hline $\mathrm{Cd}$ & $\mathrm{K} \alpha$ & $\mathrm{CdS}$ \\
\hline $\mathrm{Mn}$ & $\mathrm{K} \alpha$ & $\mathrm{MnTiO}_{3}$ \\
\hline $\mathrm{Cu}$ & $\mathrm{K} \alpha$ & $\mathrm{Cu}_{2} \mathrm{O}$ \\
\hline $\mathrm{Pb}$ & $\mathrm{M} \alpha$ & $\mathrm{PbS}$ \\
\hline $\mathrm{Ag}$ & $\mathrm{L} \alpha$ & $\mathrm{Ag}$ \\
\hline $\mathrm{Hg}$ & $\mathrm{M} \alpha$ & $\mathrm{HgS}$ \\
\hline $\mathrm{Sn}$ & $\mathrm{L} \alpha$ & $\mathrm{SnO} 2$ \\
\hline $\mathrm{Bi}$ & $\mathrm{M} \alpha$ & $\mathrm{Bi}$ \\
\hline $\mathrm{Ge}$ & $\mathrm{L} \alpha$ & $\mathrm{Ge}$ \\
\hline $\mathrm{Ni}$ & $\mathrm{K} \alpha$ & $\mathrm{Ni}$ \\
\hline $\mathrm{Co}$ & $\mathrm{K} \alpha$ & $\mathrm{Co}$ \\
\hline As & $\mathrm{K} \alpha$ & AsGa \\
\hline $\mathrm{S}$ & $\mathrm{K} \alpha$ & $\mathrm{FeS}_{2}$ \\
\hline $\mathrm{W}$ & $\mathrm{M} \alpha$ & $\mathrm{W}$ \\
\hline In & $\mathrm{L} \alpha$ & $\operatorname{InP}$ \\
\hline $\mathrm{Si}$ & $\mathrm{K} \alpha$ & Orthoclase \\
\hline $\mathrm{Al}$ (in chlorite) & $\mathrm{K} \alpha$ & Orthoclase \\
\hline $\mathrm{Al}$ (in montebrasite) & $\mathrm{K} \alpha$ & Almandine \\
\hline $\mathrm{Ti}$ & $\mathrm{K} \alpha$ & $\mathrm{MnTiO}_{3}$ \\
\hline $\mathrm{Fe}$ & $\mathrm{K} \alpha$ & $\mathrm{Fe} 2 \mathrm{O}_{3}$ \\
\hline $\mathrm{Mg}$ & $\mathrm{K} \alpha$ & $\mathrm{MgO}$ \\
\hline $\mathrm{Mn}$ & $\mathrm{K} \alpha$ & $\mathrm{MnTiO}_{3}$ \\
\hline $\mathrm{Ca}$ & $\mathrm{K} \alpha$ & Apatite \\
\hline $\mathrm{Ba}$ & $\mathrm{L} \alpha$ & BaSo4 \\
\hline $\mathrm{Na}$ & $\mathrm{K} \alpha$ & Albite \\
\hline $\mathrm{K}$ & $\mathrm{K} \alpha$ & Orthoclase \\
\hline $\mathrm{Cs}$ & $\mathrm{L} \alpha$ & Cs Glass \\
\hline $\mathrm{Rb}$ & $\mathrm{L} \alpha$ & $\mathrm{Rb}$ Glass \\
\hline$P$ & $\mathrm{~K} \alpha$ & Apatite \\
\hline F & $\mathrm{K} \alpha$ & $\mathrm{CaF}$ \\
\hline
\end{tabular}

Table 1. Elements, analytical lines and standards used for electron microprobe analyses 


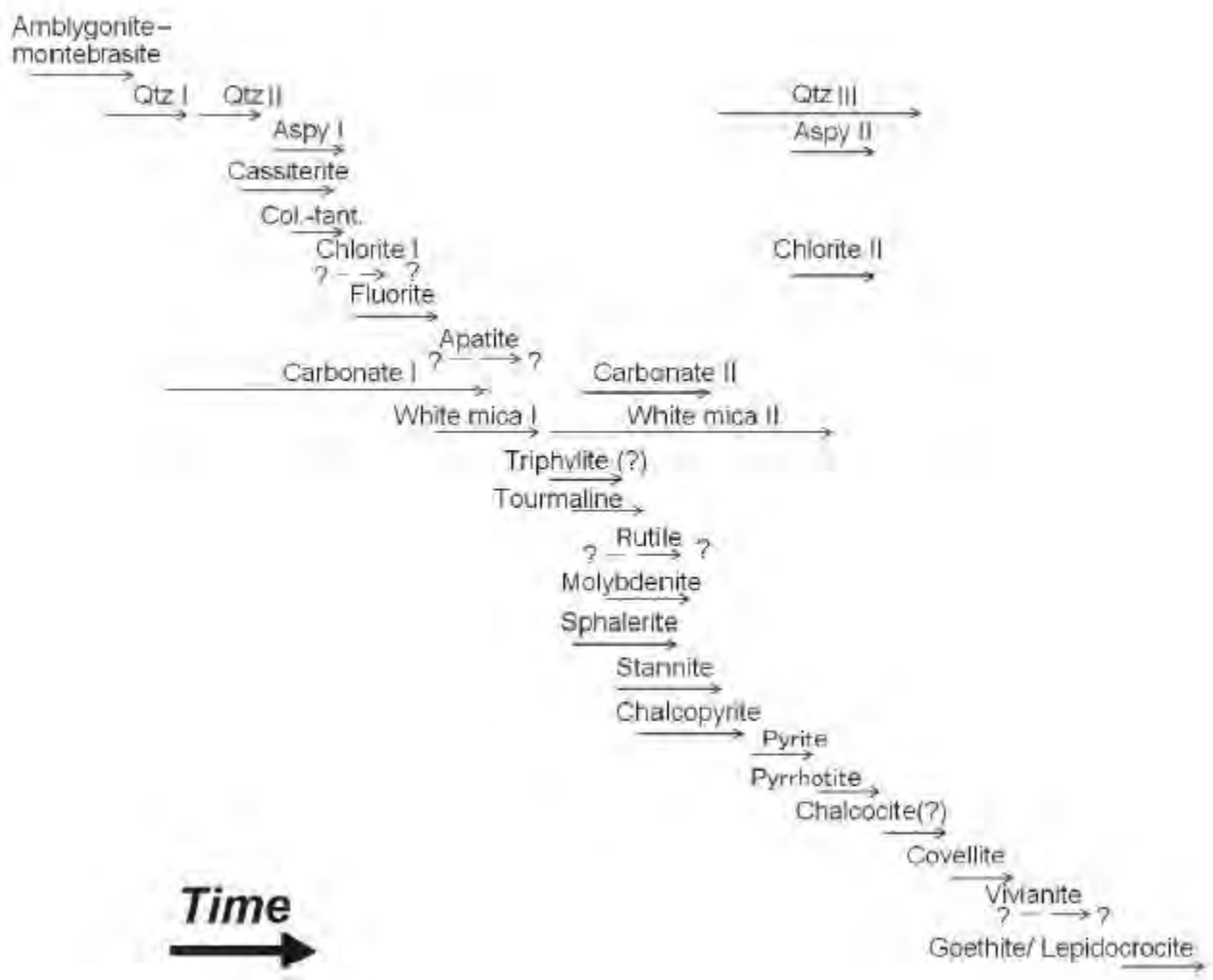

Table 2. Paragenetic sequence of Argemela stockwork vein minerals 


\begin{tabular}{|c|c|c|c|c|c|c|c|}
\hline Host & \begin{tabular}{|l|}
$\begin{array}{l}\text { F.I. } \\
\text { genetic } \\
\text { type }\end{array}$ \\
\end{tabular} & FIA & \begin{tabular}{|l} 
Inclusion \\
type
\end{tabular} & \begin{tabular}{|l} 
Inclusion \\
size $(\mu \mathrm{m})$
\end{tabular} & Shape & V/L ratios & $\mathrm{V} / \mathrm{T}$ ratios \\
\hline \multirow[b]{3}{*}{ Quartz I } & $\mathrm{P}$ & Growth zones & $L+V$ & $1-3$ & $\begin{array}{l}\text { Mostly elongated, } \\
\text { rounded or ir- } \\
\text { regular }\end{array}$ & Consistent & $\cong 5 \%$ \\
\hline & $\bar{P}$ & Growth zones & $\mathrm{V}$ & $4-10$ & Irregular & -- & --- \\
\hline & $\mathrm{S}$ & Fissures & $L+V$ & a few $\mu \mathrm{m}$ & $\begin{array}{l}\text { Mostly elongated, } \\
\text { rounded or } \\
\text { irregular; } \\
\text { rarely negative- } \\
\text { crystal } \\
\end{array}$ & Inconsistent & $10(-20) \%$ \\
\hline \multirow{4}{*}{ Quartz II } & $\mathrm{S}$ & Fissures & V & $\leq 50-60$ & Irregular & --- & --- \\
\hline & $\mathrm{P}$ & Growth zones & $\mathrm{L}+\mathrm{V}$ & $\begin{array}{l}1-2 \\
\text { (rarely 5) }\end{array}$ & $\begin{array}{l}\text { Rounded, } \\
\text { elongated } \\
\text { or irregular }\end{array}$ & Consistent & $5-10 \%$ \\
\hline & PS & $\begin{array}{l}\text { Inner part of } \\
\text { overgrowths }\end{array}$ & $L+V$ & $1.5-3.5$ & $\begin{array}{l}\text { Rounded, } \\
\text { elongated } \\
\text { or irregular } \\
\end{array}$ & Consistent & $5-10 \%$ \\
\hline & P, PS & $\begin{array}{l}\text { Growth zones } \\
+ \\
\text { inner part of } \\
\text { overgrowths } \\
\end{array}$ & V & $2-5$ & Irregular & --- & --- \\
\hline \multirow{2}{*}{$\begin{array}{l}\text { C a r b o n - } \\
\text { ate I }\end{array}$} & $\mathrm{P}$ & Growth zones & $\mathrm{L}+\mathrm{V}$ & $1-2.5$ & $\begin{array}{l}\text { Rounded; rarely } \\
\text { triangular or elon- } \\
\text { gated }\end{array}$ & Consistent & $2-5 \%$ \\
\hline & $\mathrm{S}$ & $\begin{array}{l}\text { Cleavage } \\
\text { planes }\end{array}$ & $L+V$ & $\leq 50-60$ & Elongated & Inconsistent & $2-20 \%$ \\
\hline \multirow[t]{2}{*}{ Apatite } & $\mathrm{P}$ & Growth zones & $\begin{array}{l}\mathrm{L}+\mathrm{V} \\
\mathrm{L}+\mathrm{V}\end{array}$ & $\mid \begin{array}{l}1-4(5) \\
5-15\end{array}$ & $\begin{array}{l}\text { Rounded, } \\
\text { elongated or } \\
\text { negative-crystal } \\
\text { Tubular } \\
\end{array}$ & $\begin{array}{l}\text { Consistent } \\
\text { Consistent }\end{array}$ & $5 \%$ \\
\hline & $P$ & Growth zones & $\mathrm{V}$ & $14-60$ & Tubular & - & - \\
\hline \multirow{4}{*}{ Cassiterite } & $\mathrm{P}$ & $\begin{array}{l}\text { Growth } \\
\text { bands }\end{array}$ & $\mathrm{L}+\mathrm{V}$ & $\begin{array}{l}<1-3 \\
(\text { r a r e } 1 \text { y } \\
4-6)\end{array}$ & $\begin{array}{l}\text { Rounded, } \\
\text { elongated, } \\
\text { irregular or } \\
\text { neg.-crystal } \\
\end{array}$ & Consistent & $5(-10) \%$ \\
\hline & & & $L+V$ & $>25$ & $\begin{array}{l}\text { Tubular } \\
\text { (very rare) }\end{array}$ & Consistent & $5(-10) \%$ \\
\hline & $\mathrm{P}$ & $\begin{array}{l}\text { Growth } \\
\text { bands }\end{array}$ & $\mathrm{V}$ & $5-15$ & Irregular & $\mid--$ & --- \\
\hline & $S$ & Fissures & $\mathrm{L}+\mathrm{V}, \mathrm{V}$ & $<5-50$ & Stringy or irregular & -- & --- \\
\hline
\end{tabular}

Table 3. General characteristics of fluid inclusions, including host, genetic type, FIA type, inclusion type, size, shape, V/L and V/T ratios for Argemela stockwork quartz I, quartz II, carbonate I, apatite and cassiterite. 


\begin{tabular}{|c|c|c|c|c|c|c|c|c|c|c|c|}
\hline $\begin{array}{c}\text { Sample no. } \\
\quad \text { (subsoil } \\
\text { elevation - s.e.) }\end{array}$ & $\begin{array}{c}\text { Drill- } \\
\text { hole, } \mathrm{m}\end{array}$ & $\begin{array}{l}\text { Host } \\
\text { mineral }\end{array}$ & Grain & $\begin{array}{l}\text { F.I. } \\
\text { genetic } \\
\text { type }\end{array}$ & $\begin{array}{c}\text { FIA \#; } \\
\text { number of } \\
\text { inclusions }\end{array}$ & $\mathrm{T}_{\mathrm{h}}\left({ }^{\circ} \mathrm{C}\right)^{1}$ & $\begin{array}{l}\text { Avg. } T_{h} \\
\left({ }^{\circ} \mathrm{C}\right)\end{array}$ & $\mathrm{T}_{\mathrm{m}}\left({ }^{\circ} \mathrm{C}\right)^{3}$ & $\begin{array}{l}\text { Avg. } T_{m} \\
\left({ }^{\circ} \mathrm{C}\right)\end{array}$ & $\begin{array}{l}\text { Salinity } \\
\text { (wt-\% } \mathrm{NaCl} \\
\text { equiv.) }\end{array}$ & $\begin{array}{l}\text { Avg. Salinity } \\
\text { (wt-\% } \mathrm{NaCl} \\
\text { equiv.) }\end{array}$ \\
\hline \multirow{7}{*}{$\begin{array}{c}\text { SA1-5 } \\
\text { (260 m s.e.) }\end{array}$} & SA-1, & \multirow[t]{5}{*}{ Qtz I } & 1 & $\mathrm{P}$ & FIA- $1 ; 6$ & $292.5-337.5^{2}$ & 319.5 & -5.75 to $-5.25^{3,4}$ & -5.50 & $8.21-8.88^{5}$ & 8.56 \\
\hline & 413.5 & & 2 & $P$ & FIA- $1 ; 4$ & $302.5^{2}$ & 302.5 & -8.25 to -4.75 & -6.08 & $7.52-11.99^{5,6}$ & 9.24 \\
\hline & & & 3 & $\mathrm{P}$ & FIA- $1 ; 6$ & 335 & 335 & -9.75 to -4.75 & -7.17 & $7.52-13.67^{5,6,7}$ & 10.58 \\
\hline & & & 4 & $\mathrm{P}$ & FIA- $1 ; 7$ & $315-335$ & 325 & -9.75 to -4.5 & -6.79 & $7.2-13.67^{4,5,6,7}$ & 10.12 \\
\hline & & & & $\mathrm{P}$ & FIA- $2 ; 1$ & 315 & 315 & --- & -- & --- & --- \\
\hline & & \multirow[t]{2}{*}{ Carb. I } & 1 & $P / P ?$ & FIA- $1 ; 3$ & 315 & 315 & -5.75 & -5.75 & $8.88^{5}$ & 8.88 \\
\hline & & & & $P$ & FIA- $2 ; 3$ & --- & --- & -9.75 to -6.75 & -8.42 & $10.18-13.67^{6,7}$ & 12.14 \\
\hline \multirow{5}{*}{$\begin{array}{c}\text { SA1-1 } \\
\text { (379 m s.e.) }\end{array}$} & SA-1, & \multirow[t]{5}{*}{ Cass. } & 1 & $\mathrm{P}$ & FIA-1; 2 & 355 & 355 & -14.75 & -14.75 & $18.43^{8}$ & 18.43 \\
\hline & 236.1 & & 2 & $P$ & FIA- $1 ; 4$ & $325-355$ & 342.5 & $-15,25$ to -11.25 & -13.50 & $15.22-18.84^{7,8}$ & 17.30 \\
\hline & & & 3 & $\mathrm{P}$ & FIA- $1 ; 2$ & --- & -- & -15.25 to -12.75 & -14.00 & $16.66-18.84^{7,8}$ & 17.75 \\
\hline & & & & $P$ & FIA- $2 ; 4$ & 355 & 355 & -15.25 to -12.75 & -13.88 & $16.66-18.84^{7,8}$ & 17.66 \\
\hline & & & & $P$ & FIA-3; 2 & -- & -- & -15.25 to -14.75 & -15.00 & $18.43-18.84^{8}$ & 18.64 \\
\hline \multirow{5}{*}{$\begin{array}{c}\text { SA1-3 } \\
\text { (312 m s.e.) }\end{array}$} & SA-1, & \multirow[t]{5}{*}{ Cass. } & 1 & $P$ & FIA- $1 ; 1$ & --- & --- & -11.25 & -11.25 & $15.22^{7}$ & 15.22 \\
\hline & 321.7 & & & $P$ ? & FIA-2; 2 & --- & --- & -10.75 to -9.25 & -10.00 & $14.72-13.13^{7}$ & 13.93 \\
\hline & & & 2 & P? & FIA- $1 ; 2$ & 345 & 345 & -11.25 & -11.25 & $15.22^{7}$ & 15.22 \\
\hline & & & & P? & FIA- $2 ; 4$ & $305-345$ & 325 & -13.25 to -9.75 & -11.58 & $13.67-17.12^{7}$ & 15.50 \\
\hline & & & 3 & $\mathrm{P} ? / \mathrm{P}$ & FIA- $1 ; 3$ & 355 & 355 & -14.25 to -11.75 & -12.92 & $15.72-18.01^{7,8}$ & 16.80 \\
\hline \multirow{2}{*}{$\begin{array}{c}\text { SA2-4a } \\
\text { (390 m s.e.) }\end{array}$} & SA-2, & \multirow[t]{2}{*}{ Cass. } & \multirow[t]{2}{*}{1} & $\mathrm{P} / \mathrm{P} ?$ & FIA- $1 ; 3$ & 355 & 355 & -15.00 to $-14.25^{3,4}$ & -14.67 & $18.01-18.60^{8}$ & 18.35 \\
\hline & 179.9 & & & $P ?$ & FIA- $2 ; 1$ & 355 & 355 & --- & --- & --- & --- \\
\hline \multirow{2}{*}{$\begin{array}{c}\text { SA2-7a } \\
\text { (230 m s.e.) }\end{array}$} & SA-2, & \multirow[t]{2}{*}{ Cass. } & \multirow[t]{2}{*}{1} & $P$ & FIA- $1 ; 1$ & 345 & 345 & --- & --. & --- & --. \\
\hline & 385.0 & & & $P$ & FIA- $2 ; 2$ & --- & -- & -11.75 to $-10.5^{3,4}$ & -11.13 & $14.50-15.72^{7}$ & 15.11 \\
\hline \multirow{5}{*}{$\begin{array}{c}\text { SA3-5 } \\
\text { (171 m s.e.) }\end{array}$} & $\mathrm{SA}-3$ & \multirow[t]{2}{*}{ Cass. } & \multirow[t]{5}{*}{1} & $P$ & FIA-1; 2 & --- & -- & -15.25 to -14.25 & -14.75 & $18.01-18.84^{8}$ & 18.43 \\
\hline & 391.1 & & & $\mathrm{P}$ & FIA- $2 ; 3$ & 355 & 355 & -14.75 & -14.75 & $18.01^{8}$ & 18.43 \\
\hline & & \multirow[t]{3}{*}{ Apatite } & & P? & FIA- $1 ; 2$ & -- & -- & -11.0 to $-8.25^{3,4}$ & -9.63 & $11.99-15.00^{6}$ & 13.50 \\
\hline & & & & $P$ ? & FIA- $1 ; 3$ & --- & --- & -10.25 to $-7.25^{3,4}$ & -8.83 & $10.80-14.20^{6,7}$ & 12.63 \\
\hline & & & & $P$ ? & FIA- $1 ; 3$ & $335-345$ & 340 & -8.75 to -5.75 & -7.25 & $8.88-12.57^{5.6}$ & 10.73 \\
\hline
\end{tabular}

Abbreviations: F.I. = fluid inclusion, FIA = fluid inclusion assemblage, $\mathrm{P}=$ primary (in growth zone/band) fluid inclusion, $\mathrm{P}$ ? $=$ primary inclusion along growth zone/band, in proximity to microfissure with secondary inclusions, Qtz I = quartz I, Carb. I = carbonate I, Cass. = cassiterite

${ }^{1}$ Midpoint temperature $\left(T_{h}\right)$ of a $10^{\circ} \mathrm{C}$ interval, unless stated otherwise

${ }^{2}$ Midpoint temperature $\left(T_{h}\right)$ of a $5^{\circ} \mathrm{C}$ interval

${ }^{3}$ Midpoint temperature $\left(\mathrm{T}_{\mathrm{m}}\right)$ of a $0.5^{\circ} \mathrm{C}$ interval, unless stated otherwise

${ }^{4}$ One-number temperature (Tm)

${ }^{5}$ Midpoint salinity of a $0.7 \mathrm{wt}-\% \mathrm{NaCl}$ equiv, interval

${ }^{6}$ Midpoint salinity of a $0.6 \mathrm{wt}-\% \mathrm{NaCl}$ equiv. interval

${ }^{7}$ Midpoint salinity of a $0.5 \mathrm{wt}-\% \mathrm{NaCl}$ equiv. interval

${ }^{8}$ Midpoint salinity of a $0.4 \mathrm{wt}-\% \mathrm{NaCl}$ equiv. interval

Table 4. Microthermometric data from FIAs with primary inclusions in growth zones from quartz I, carbonate I, apatite and cassiterite in Argemela stockwork veins. 


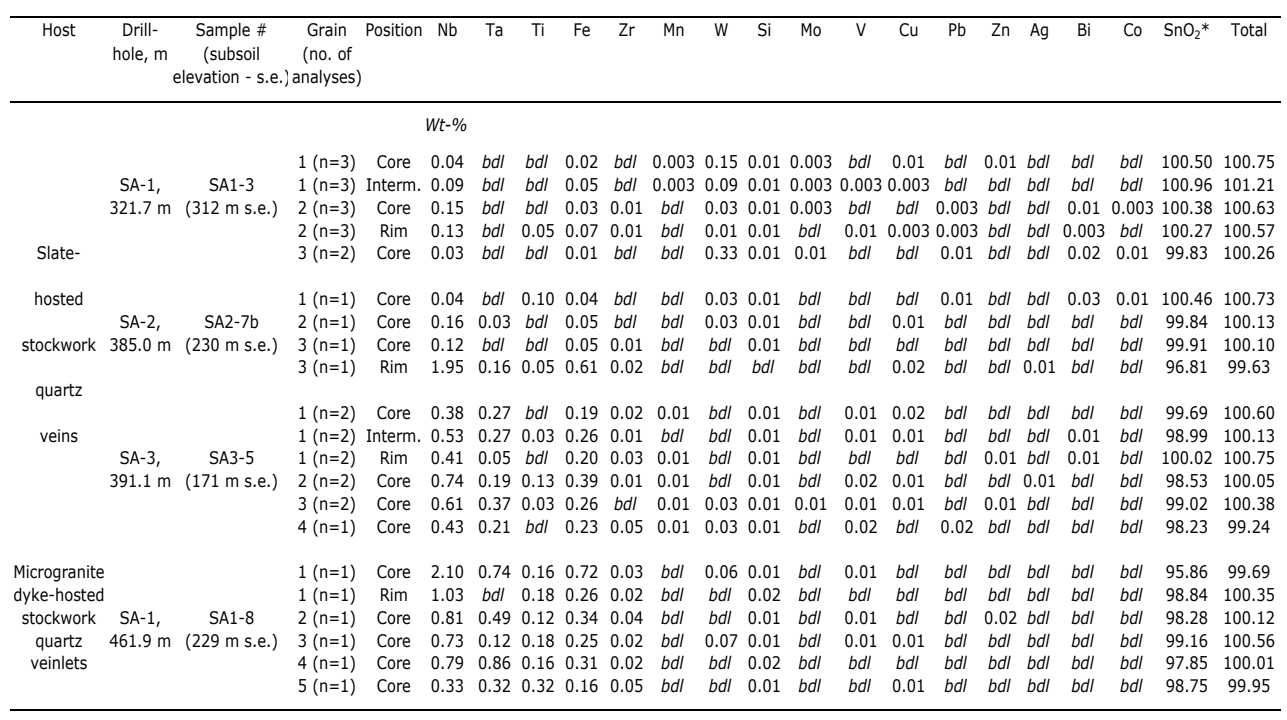

* The total was computed, with respect to $\mathrm{Sn}$, not by the use of $\mathrm{SnO}_{2}$ percentage, but of $\mathrm{Sn}$ and $\mathrm{O}$ proportions in it

bdl $=$ below detection limit or $0.00 w t \%$

The concentrations obtained for As, Sb, In, Sc and Ge were bdl in all analyses

Table 5. Electron microprobe analyses of cassiterite from Argemela stockwork veins. 


\begin{tabular}{|c|c|c|c|c|}
\hline Drill-hole, $\mathrm{m}$ & SA-2, 385.0 & SA-3, 372.6 & SA-1, 420.2 & SA-3, 216.5 \\
\hline $\begin{array}{c}\text { Sample \# } \\
\text { (subsoil } \\
\text { elevation - s.e.) }\end{array}$ & $\begin{array}{l}\text { SA2-7a } \\
\text { ( } 230 \mathrm{~m} \text { s.e.) }\end{array}$ & $\begin{array}{l}\text { SA3-4 } \\
\text { (190 m s.e.) }\end{array}$ & $\begin{array}{l}\text { SA1-6 } \\
\text { ( } 255 \mathrm{~m} \text { s.e.) }\end{array}$ & $\begin{array}{l}\text { SA3-1a } \\
\text { (320 m s.e.) }\end{array}$ \\
\hline \multicolumn{4}{|l|}{ No. of analysed } & 8 \\
\hline \multicolumn{5}{|l|}{$W t-\%$} \\
\hline $\mathrm{Zn}$ & 65.48 & 64.88 & 65.46 & 56.40 \\
\hline $\mathrm{Fe}$ & 1.17 & 1.35 & 1.10 & 8.84 \\
\hline $\mathrm{Cd}$ & 0.45 & 0.43 & 0.52 & 1.02 \\
\hline $\mathrm{Mn}$ & 0.01 & 0.01 & 0.01 & 0.02 \\
\hline $\mathrm{Cu}$ & 0.07 & 0.03 & 0.03 & 0.10 \\
\hline $\mathrm{Pb}$ & 0.04 & 0.06 & 0.04 & 0.06 \\
\hline Sn & 0.003 & $b d l$ & $b d l$ & $b d l$ \\
\hline W & 0.06 & 0.10 & 0.07 & 0.03 \\
\hline $\mathrm{Bi}$ & 0.09 & 0.11 & 0.11 & 0.08 \\
\hline In & $b d l$ & 0.001 & $b d l$ & $b d l$ \\
\hline $\mathrm{Ge}$ & 0.001 & 0.003 & 0.01 & $b d l$ \\
\hline $\mathrm{Ni}$ & 0.01 & 0.003 & 0.01 & 0.01 \\
\hline Co & 0.004 & 0.01 & 0.01 & 0.02 \\
\hline As & $b d l$ & 0.004 & $b d l$ & $b d l$ \\
\hline $\mathrm{S}$ & 32.52 & 32.45 & 32.58 & 32.81 \\
\hline Total & 99.90 & 99.43 & 99.95 & 99.39 \\
\hline mole $\%$ FeS & 2.10 & 2.44 & 1.95 & 15.92 \\
\hline \multicolumn{5}{|c|}{ Atomic proportions (2 atoms) } \\
\hline $\mathrm{Zn}$ & 0.978 & 0.975 & 0.980 & 0.839 \\
\hline $\mathrm{Fe}$ & 0.021 & 0.024 & 0.019 & 0.154 \\
\hline $\mathrm{Cd}$ & 0.004 & 0.004 & 0.005 & 0.009 \\
\hline $\mathrm{Mn}$ & 0.0006 & 0.0003 & 0.0005 & 0.001 \\
\hline $\mathrm{Cu}$ & 0.001 & 0.001 & 0.001 & 0.002 \\
\hline $\mathrm{Pb}$ & 0.0003 & 0.0003 & 0.0003 & 0.001 \\
\hline Sn & 0.0002 & - & - & - \\
\hline W & 0.0007 & 0.001 & 0.001 & 0.0003 \\
\hline $\mathrm{Bi}$ & 0.0005 & 0.001 & 0.001 & 0.001 \\
\hline In & - & 0.0001 & - & - \\
\hline $\mathrm{Ge}$ & 0.0001 & 0.0002 & 0.001 & - \\
\hline $\mathrm{Ni}$ & 0.0003 & 0.0003 & 0.0003 & 0.0003 \\
\hline Co & 0.0002 & 0.0003 & 0.0003 & 0.0004 \\
\hline As & - & 0.001 & - & - \\
\hline$S$ & 0.996 & 0.995 & 0.994 & 0.995 \\
\hline Total & 2.003 & 2.004 & 2.003 & 2.003 \\
\hline
\end{tabular}

$b d l=$ below detection limit or $0.00 w t \%$

The concentrations obtained for $\mathrm{Ag}, \mathrm{Hg}$, Sb and Se were bdl in all analyses

Table 6. Electron microprobe analyses (averages) of sphalerite from Argemela slate-hosted stockwork veins. 
CAD. LAB. XEOL. LAXE 41 (2019) The granite-related, high-tonnage Sn-Li deposit of Argemela... 253

\begin{tabular}{|c|c|c|c|c|c|c|c|}
\hline \multirow{2}{*}{$\begin{array}{c}\text { Drill-hole, m } \\
\text { Sample \# } \\
\text { (subsoil } \\
\text { elevation - s.e.) }\end{array}$} & \multicolumn{2}{|c|}{ SA-2, 385.0} & \multicolumn{2}{|c|}{ SA-3, 372.6} & \multicolumn{2}{|c|}{ SA-1, 420.2} & SA-3, 216.5 \\
\hline & \multicolumn{2}{|c|}{$\begin{array}{l}\text { SA2-7a } \\
\text { (230 m s.e.) }\end{array}$} & \multicolumn{2}{|c|}{$\begin{array}{c}\text { SA3-4 } \\
\text { (190 m s.e.) }\end{array}$} & \multicolumn{2}{|c|}{$\begin{array}{c}\text { SA1-6 } \\
\text { (255 m s.e.) }\end{array}$} & $\begin{array}{c}\text { SA3-1a } \\
\text { (320 m s.e.) }\end{array}$ \\
\hline \multicolumn{8}{|l|}{ No. of analysed } \\
\hline grains & 7 & 1 & 6 & 3 & 2 & 7 & 8 \\
\hline Mineral & $\begin{array}{c}\text { ferro- } \\
\text { kesterite }\end{array}$ & kesterite & $\begin{array}{c}\text { ferro- } \\
\text { kesterite }\end{array}$ & kesterite & $\begin{array}{c}\text { ferro- } \\
\text { kesterite }\end{array}$ & kesterite & stannite \\
\hline \multicolumn{8}{|l|}{$W t-\%$} \\
\hline $\mathrm{Zn}$ & 6.07 & 8.17 & 6.05 & 7.42 & 6.04 & 7.30 & 1.72 \\
\hline $\mathrm{Fe}$ & 8.03 & 5.92 & 7.73 & 6.68 & 7.74 & 6.91 & 11.97 \\
\hline $\mathrm{Cd}$ & 0.19 & 0.11 & 0.12 & 0.11 & 0.18 & 0.13 & 0.01 \\
\hline $\mathrm{Mn}$ & 0.004 & 0.02 & 0.01 & 0.003 & $b d l$ & 0.02 & 0.01 \\
\hline $\mathrm{Cu}$ & 29.23 & 29.38 & 28.73 & 28.30 & 28.81 & 28.63 & 28.82 \\
\hline $\mathrm{Pb}$ & 0.04 & 0.04 & 0.01 & 0.05 & 0.03 & 0.05 & 0.03 \\
\hline $\mathrm{Ag}$ & 0.004 & 0.02 & 0.19 & 0.31 & 0.01 & 0.08 & 0.14 \\
\hline $\mathrm{Hg}$ & 0.01 & $b d l$ & 0.002 & $b d l$ & $b d l$ & $b d l$ & 0.001 \\
\hline Sn & 27.75 & 27.88 & 27.91 & 27.68 & 27.74 & 27.73 & 27.74 \\
\hline $\mathrm{Bi}$ & 0.10 & 0.06 & 0.10 & 0.04 & 0.06 & 0.11 & 0.10 \\
\hline $\mathrm{Ge}$ & 0.01 & $b d l$ & $b d l$ & $b d l$ & $b d l$ & 0.004 & 0.01 \\
\hline $\mathrm{Ni}$ & 0.01 & 0.04 & 0.01 & 0.003 & $b d l$ & 0.01 & 0.003 \\
\hline Co & 0.01 & 0.02 & 0.01 & 0.01 & 0.02 & 0.01 & 0.02 \\
\hline As & 0.01 & $b d l$ & $b d l$ & $b d l$ & 0.02 & $b d l$ & $b d l$ \\
\hline$S$ & 29.25 & 29.02 & 28.63 & 28.44 & 28.84 & 28.83 & 29.27 \\
\hline Total & 100.72 & 100.68 & 99.50 & 99.05 & 99.49 & 99.81 & 99.84 \\
\hline \multicolumn{8}{|c|}{ Atomic proportions (8 atoms) } \\
\hline $\mathrm{Zn}$ & 0.403 & 0.545 & 0.408 & 0.503 & 0.406 & 0.490 & 0.114 \\
\hline $\mathrm{Fe}$ & 0.624 & 0.462 & 0.610 & 0.530 & 0.609 & 0.543 & 0.930 \\
\hline $\mathrm{Cd}$ & 0.006 & 0.004 & 0.005 & 0.006 & 0.007 & 0.005 & 0.001 \\
\hline $\mathrm{Mn}$ & 0.002 & 0.002 & 0.001 & 0.001 & - & 0.001 & 0.001 \\
\hline $\mathrm{Cu}$ & 1.994 & 2.014 & 1.993 & 1.976 & 1.993 & 1.979 & 1.969 \\
\hline $\mathrm{Pb}$ & 0.001 & 0.001 & 0.001 & 0.001 & 0.001 & 0.001 & 0.001 \\
\hline $\mathrm{Ag}$ & 0.002 & 0.001 & 0.008 & 0.013 & 0.001 & 0.003 & 0.006 \\
\hline $\mathrm{Hg}$ & 0.001 & - & 0.0001 & - & - & - & 0.0002 \\
\hline Sn & 1.014 & 1.023 & 1.037 & 1.035 & 1.027 & 1.026 & 1.014 \\
\hline $\mathrm{Bi}$ & 0.002 & 0.002 & 0.002 & 0.002 & 0.002 & 0.002 & 0.002 \\
\hline $\mathrm{Ge}$ & 0.002 & - & - & - & - & 0.002 & 0.002 \\
\hline $\mathrm{Ni}$ & 0.002 & 0.003 & 0.001 & 0.001 & - & 0.002 & 0.002 \\
\hline Co & 0.002 & 0.002 & 0.002 & 0.002 & 0.002 & 0.002 & 0.002 \\
\hline As & 0.001 & - & - & - & 0.002 & - & - \\
\hline$S$ & 3.955 & 3.942 & 3.937 & 3.935 & 3.954 & 3.949 & 3.962 \\
\hline Total & 8.011 & 8.001 & 8.005 & 8.005 & 8.004 & 8.005 & 8.006 \\
\hline
\end{tabular}

$b d l=$ below detection limit or $0.00 w t \%$

Concentrations for $W, I n, S b$ and Se were bdl or $0.00 \%$ in all cases

Table 7. Electron microprobe analyses (averages) of stannite group minerals from Argemela slate-hosted stockwork veins. 


\begin{tabular}{|c|c|c|c|c|c|c|c|c|c|c|c|c|c|}
\hline \multirow[t]{2}{*}{ Host } & \multirow{2}{*}{$\begin{array}{c}\text { Drill- } \\
\text { hole, m }\end{array}$} & \multirow{2}{*}{$\begin{array}{c}\text { Sample \# } \\
\text { (subsoil } \\
\text { elevation - s.e.) }\end{array}$} & \multirow{2}{*}{$\begin{array}{c}\text { No. of } \\
\text { analysed } \\
\text { grains }\end{array}$} & \multirow[t]{2}{*}{$\mathrm{Na}_{2} \mathrm{O}$} & \multirow[t]{2}{*}{$\mathrm{Al}_{2} \mathrm{O}_{3}$} & \multirow[t]{2}{*}{$\mathrm{P}_{2} \mathrm{O}_{5}$} & \multirow[t]{2}{*}{$\mathrm{CaO}$} & \multirow[t]{2}{*}{$\mathrm{FeO}$} & \multirow[t]{2}{*}{$\mathrm{MnO}$} & \multirow[t]{2}{*}{$\mathrm{F}$} & \multirow[t]{2}{*}{$-\mathrm{O} \equiv \mathrm{F}$} & \multicolumn{2}{|c|}{$\%$ ambligonite } \\
\hline & & & & & & & & & & & & range & avg. \\
\hline \multirow{4}{*}{$\begin{array}{l}\text { Slate- } \\
\text { hosted } \\
\text { stockwork } \\
\text { quartz } \\
\text { veins }\end{array}$} & & & & $w t-\%$ & & & & & & & & & \\
\hline & $\begin{array}{c}\text { SA-1, } \\
321.2 \mathrm{~m}\end{array}$ & $\begin{array}{c}\text { SA1-2 } \\
\text { (310 m s.e.) }\end{array}$ & 7 & 0.003 & 33.72 & 49.41 & 0.08 & 0.06 & 0.12 & 1.43 & -0.60 & $09--14$ & 11 \\
\hline & $\begin{array}{c}\text { SA-1, } \\
420.2 \mathrm{~m}\end{array}$ & $\begin{array}{c}\text { SA1-6 } \\
\text { (255 m s.e.) }\end{array}$ & 5 & 0.01 & 34.24 & 48.37 & 0.01 & 0.04 & 0.02 & 1.92 & -0.81 & $12--19$ & 15 \\
\hline & $\begin{array}{c}\text { SA-2, } \\
353.5 \mathrm{~m}\end{array}$ & $\begin{array}{c}\text { SA2-5a } \\
(255 \text { m s.e.) }\end{array}$ & 10 & 0.01 & 34.12 & 48.43 & 0.02 & 0.07 & 0.10 & 2.14 & -0.90 & $14--20$ & 17 \\
\hline $\begin{array}{c}\text { Microgranite } \\
\text { dyke-hosted } \\
\text { stw quartz } \\
\text { veinlets }\end{array}$ & $\begin{array}{c}\text { SA-1, } \\
461.9 \mathrm{~m}\end{array}$ & $\begin{array}{c}\text { SA1-8 } \\
\text { (229 m s.e.) }\end{array}$ & 8 & 0.01 & 34.38 & 49.12 & 0.01 & 0.11 & 0.11 & 1.77 & -0.65 & $7--18$ & 14 \\
\hline
\end{tabular}

Table 8. Electron microprobe analyses (averages) of amblygonite-montebrasite (not including Li2O concentrations) from Argemela slate-hosted and microgranite dyke-hosted stockwork vein(let)s.

\begin{tabular}{|c|c|c|c|c|}
\hline Driil-hole/m & \multicolumn{2}{|c|}{ SA-1/461.9 m } & & \\
\hline $\begin{array}{c}\text { Sample \# } \\
\text { (subsoil } \\
\text { elevation - s.e.) }\end{array}$ & \multicolumn{2}{|c|}{$\begin{array}{c}\text { SA1-8 } \\
(229 \mathrm{~m} \text { s.e. })\end{array}$} & & \\
\hline $\begin{array}{l}\text { No. of analysed } \\
\text { grains }\end{array}$ & 5 & & & \\
\hline$W t-\%$ & \multicolumn{4}{|c|}{ Cations (for 240 ) } \\
\hline $\mathrm{SiO}_{2}$ & 3760 & $\mathrm{Si}$ & 7.452 & \\
\hline \multirow{2}{*}{$\mathrm{Al}_{2} \mathrm{O}_{3}$} & 23.77 & $\mathrm{Al}(\mathrm{IV})$ & 0.548 & 8.000 \\
\hline & & $\mathrm{Al}(\mathrm{VI})$ & 5.005 & \\
\hline $\mathrm{TiO}_{2}$ & 0.07 & $\mathrm{Ti}$ & 0.010 & \\
\hline $\mathrm{FeO}$ & 24.87 & $\mathrm{Fe}$ & 4.118 & \\
\hline $\mathrm{MgO}$ & 1.18 & $\mathrm{Mg}$ & 0.349 & \\
\hline $\mathrm{MnO}$ & 0.10 & $\mathrm{Mn}$ & 0.017 & \\
\hline $\mathrm{CaO}$ & 0.51 & $\mathrm{Ca}$ & 0.109 & \\
\hline $\mathrm{BaO}$ & 0.05 & $\mathrm{Ba}$ & 0.004 & 9.755 \\
\hline $\mathrm{Na}_{2} \mathrm{O}$ & 0.07 & $\mathrm{Na}$ & 0.025 & \\
\hline $\mathrm{K}_{2} \mathrm{O}$ & 0.30 & $\mathrm{~K}$ & 0.075 & \\
\hline $\mathrm{Cs}_{2} \mathrm{O}$ & 0.01 & Cs & 0.001 & \\
\hline $\mathrm{Rb}_{2} \mathrm{O}$ & $b d l$ & $\mathrm{Rb}$ & - & \\
\hline $\mathrm{P}_{2} \mathrm{O}_{5}$ & 0.18 & $\mathrm{P}$ & 0.040 & \\
\hline $\mathrm{F}$ & 0.004 & $\mathrm{~F}$ & 0.002 & \\
\hline Total & 88.71 & $\mathrm{Fe} /(\mathrm{Fe}+\mathrm{Mn})$ & 0.922 & \\
\hline
\end{tabular}

Table 9. Electron microprobe analyses (averages) of chlorite (not including $\mathrm{Li}_{2} \mathrm{O}$ concentrations) from Argemela microgranite dyke-hosted stockwork veinlets. 
CAD. LAB. XEOL. LAXE 41 (2019) The granite-related, high-tonnage Sn-Li deposit of Argemela... 255

\begin{tabular}{|c|c|c|c|c|c|c|c|c|c|}
\hline Sample & Pair & Mineral & Fe (wt-\%) & Zn (wt-\%) & $\mathrm{Fe} / \mathrm{Zn}$ & $\mathrm{Kd}$ & $\log K d$ & $\mathrm{t}^{\circ} \mathrm{C}(1)$ & $\mathrm{t}^{\circ} \mathrm{C}(2)$ \\
\hline \multirow{6}{*}{ SA2-7A } & 1 & sphalerite & 1.17 & 64.39 & 0.02 & \multirow[t]{2}{*}{0.01} & \multirow[t]{2}{*}{-1.89} & \multirow[t]{2}{*}{142} & \multirow[t]{2}{*}{246} \\
\hline & 1 & ferrokesterite & 8.21 & 5.73 & 1.43 & & & & \\
\hline & 2 & sphalerite & 1.19 & 65.72 & 0.02 & \multirow[t]{2}{*}{0.01} & \multirow[t]{2}{*}{-1.85} & \multirow[t]{2}{*}{148} & \multirow[t]{2}{*}{250} \\
\hline & 2 & ferrokesterite & 7.83 & 6.15 & 1.27 & & & & \\
\hline & 3 & sphalerite & 1.14 & 65.48 & 0.02 & \multirow[t]{2}{*}{0.02} & \multirow[t]{2}{*}{-1.62} & \multirow[t]{2}{*}{183} & \multirow[t]{2}{*}{274} \\
\hline & 3 & kesterite & 5.92 & 8.17 & 0.72 & & & & \\
\hline \multirow{8}{*}{ SA3-4 } & 1 & sphalerite & 1.50 & 64.48 & 0.02 & \multirow[t]{2}{*}{0.02} & \multirow[t]{2}{*}{-1.71} & \multirow[t]{2}{*}{169} & \multirow[t]{2}{*}{264} \\
\hline & 1 & ferrokesterite & 7.64 & 6.40 & 1.19 & & & & \\
\hline & 2 & sphalerite & 1.29 & 64.75 & 0.02 & \multirow[t]{2}{*}{0.01} & \multirow[t]{2}{*}{-1.84} & \multirow[t]{2}{*}{150} & \multirow[t]{2}{*}{251} \\
\hline & 2 & ferrokesterite & 7.78 & 5.67 & 1.37 & & & & \\
\hline & 3 & sphalerite & 1.09 & 65.30 & 0.02 & \multirow[t]{2}{*}{0.01} & \multirow[t]{2}{*}{-1.83} & \multirow[t]{2}{*}{151} & \multirow[t]{2}{*}{252} \\
\hline & 3 & kesterite & 7.22 & 6.43 & 1.12 & & & & \\
\hline & 4 & sphalerite & 1.43 & 64.35 & 0.02 & \multirow[t]{2}{*}{0.04} & \multirow[t]{2}{*}{$-1,41$} & \multirow[t]{2}{*}{220} & \multirow[t]{2}{*}{297} \\
\hline & 4 & kesterite & 5.07 & 8.92 & 0.57 & & & & \\
\hline \multirow{7}{*}{ SA1-6 } & 1 & sphalerite & 1.11 & 65.69 & 0.02 & 0.01 & -1.90 & 142 & 246 \\
\hline & 1 & ferrokesterite & 7.76 & 5.82 & 1.33 & & & & \\
\hline & 2 & sphalerite & 1.01 & 65.06 & 0.02 & 0.01 & -1.90 & 141 & 245 \\
\hline & 2 & ferrokesterite & 7.72 & 6.25 & 1.24 & & & & \\
\hline & 3 & sphalerite & 1.03 & 65.61 & 0.02 & 0.03 & -1.57 & 191 & 279 \\
\hline & 3 & kesterite & 5.49 & 9.35 & 1.17 & & & & \\
\hline & 4 & sphalerite & 1.07 & 65.43 & 0.02 & 0.01 & -1.85 & 148 & 250 \\
\hline & 4 & kesterite & 7.74 & 6.62 & 1.17 & & & & \\
\hline & 1 & sphalerite & 8.92 & 56.65 & 0.16 & 0.02 & -1.79 & 157 & 256 \\
\hline SA3-1a & 1 & stannite & 12.21 & 1.26 & 9.69 & & & & \\
\hline & 2 & sphalerite & 9.09 & 56.11 & 0.16 & 0.03 & -1.52 & 199 & 284 \\
\hline & 2 & stannite & 12.10 & 2.23 & 5.42 & & & & \\
\hline
\end{tabular}

$\mathrm{t}^{\circ} \mathrm{C}(1)$ : Temperature based on Nekrasov et al.'s (1979) geothermometer

$t{ }^{\circ} \mathrm{C}(2)$ : Temperature based on Nakamura and Shima's (1982) geothermometer

Table 10. Chemical composition, $\mathrm{Kd}$, and formation temperatures of coexisting and in equilibrium 13 (out of 34) representative pairs of sphalerite and stannite(-group minerals) from Argemela slate-hosted stockwork veins. 